$4 / \beta^{, 4 l}$ (1) $w^{\beta}$
SANDIA REPORT

SAND91-1172 - UC-601

Unlimited Release

Printed August 1991

\title{
Manual of Analytical Methods for the Industrial Hygiene Chemistry Laboratory
}

K. A. Greulich, C. E. Gray

Prepared by

Sandia National Laboratories

Albuquerque, New Mexico 87185 and Livermore, California 94550

for the United States Department of Energy

under Contract DE-AC04-76DP00789 
Issued by Sandia National Laboratories, operated for the United States Department of Energy by Sandia Corporation.

NOTICE: This report was prepared as an account of work sponsored by an agency of the United States Government. Neither the United States Government nor any agency thereof, nor any of their employees, nor any of their contractors, subcontractors, or their employees, makes any warranty, express or implied, or assumes any legal liability or responsibility for the accuracy, completeness, or usefulness of any information, apparatus, product, or process disclosed, or represents that its use would not infringe privately owned rights. Reference herein to any specific commercial product, process, or service by trade name, trademark, manufacturer, or otherwise, does not necessarily constitute or imply its endorsement, recommendation, or favoring by the United States Government, any agency thereof or any of their contractors or subcontractors. The views and opinions expressed herein do not necessarily state or reflect those of the United States Government, any agency thereof or any of their contractors.

Printed in the United States of America. This report has been reproduced directly from the best available copy.

Available to DOE and DOE contractors from

Office of Scientific and Technical Information

PO Box 62

Oak Ridge, TN 37831

Prices available from (615) 576-8401, FTS 626-8401

Available to the public from

National Technical Information Service

US Department of Commerce

5285 Port Royal Rd

Springfield, VA 22161

NTIS price codes

Printed copy: A08

Microfiche copy: A01 


\title{
MANUAL OF ANALYTICAL METHOIS FOR THE INDUSTRIAL, IYGIENE CHEMISTRY LABORATORY
}

\author{
Compiled and Edited by: \\ K. A. Greulich and C. E. Gray \\ Industrial Hygiene/Toxicology Division - 3211 \\ Sandia National Laboratories \\ Albuquerque, NM 87185
}


THIS PAGE INTENTIONALLY LEFT BLANK 


\section{FORWARD}

This Manual. is compiled from techniques used in the Industrial Hygiene Chemistry Laboratory of Sandia National Laboratories in Albuquerque, New Mexico. It is a revision of three earlier publications, SC-M-67-3044, edited by L. W. Brewer; SAND75-0014, edited by C. E. Gray; and SAND88-1149, edited by K. A. Greulich, C. E. Gray, and B. M. Kelly.

The procedures are similar to those used in other laboratories devoted to industrial hygiene practices. Some of the methods are standard; some, modified to suit our needs; and still others, developed at Sandia. The authors have attempted to present all methods in a simple and concise manner but in sufficient detail to make them readily usable. It is not to be inferred that these methods are universal for any type of sample, but they have been found very reliable for the types of samples mentioned. The authors welcome inquiry for clarification of any part of this manual. We hope that the document will be of use and service to others.

The loose-leaf format is intended to permit the later inclusion of new and revised procedures as they become available. 


\section{CONTENTS}

SECTION A: INTRODUCTION $\quad$ A-1

Environment, Health, and Safety Concerns $A-3$

Analytical Laboratory - Field Group Interface $\quad A-5$

Chain-of-Custody Procedures for Samples Submitted to the $A-7$

Qua1ity Control $\quad A-13$

$\begin{array}{ll}\text { SECTION B: INORGANIC METHODS } & B-1\end{array}$

Common Anions in Aqueous Solutions $\quad B-3$

$\begin{array}{ll}\text { Arsenic in Air, Urine, and Water } & B-7\end{array}$

Qualitative Analysis of Bulk Asbestos $\quad$ B- 11

General Procedures for Atomic Absorption Spectroscopy $\quad B-15$

$\begin{array}{lr}\text { Chlorine in Air, Water, and Wastewater } & B-29\end{array}$

$\begin{array}{lr}\text { Hexavalent Chromium in Air and Water } & B-31\end{array}$

$\begin{array}{lr}\text { Compressed Breathing Air } & B-33\end{array}$

Cyanides and llydrocyanic Acid in Air and Water (Colorimetric Method) B-37

Cyanides in Air (Specific Ion Flectrode Method) B-41

Fluorides and Hydrogen Fluoride in Air and Water $B-43$

$\begin{array}{lr}\text { Fluorides in Urine } & B-47\end{array}$

$\begin{array}{lr}\text { Inductively-Coupled Plasma Spectroscopy } & B-51\end{array}$

$\begin{array}{lr}\text { Total Lead and Copper in Drinking Water } & B-61\end{array}$

$\begin{array}{lr}\text { Lead in Urine } & B-67\end{array}$

$\begin{array}{lr}\text { Mercury in Urine } & B-71\end{array}$

$\begin{array}{lr}\text { Nitrogen Dioxide in Air } & \text { B }-75\end{array}$

$\begin{array}{lr}\text { Ozone in Air (Colorimetric Method) } & \text { B-79 }\end{array}$

$\begin{array}{lr}\text { Ozone in Air (Titration Method) } & B-83\end{array}$

$\begin{array}{lr}\text { Sulfur Dioxide in Air } & B-85\end{array}$

$\begin{array}{lr}\text { Thallium in Urine } & B-87\end{array}$

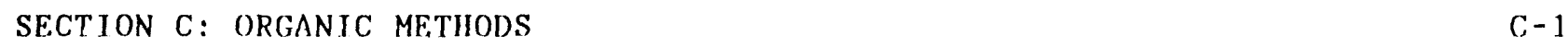

Composition of Commercial and Proprietary Products $\quad$ C -3

Flash-Point Testing with Pensky-Martens Closed Flash Tester $\quad$ C-17

Formaldeliyde in Air $\quad$ C-19

$\begin{array}{ll}0 \text { il Mist in Air } & C-23\end{array}$

$\begin{array}{lr}\text { Organjo Solvents in Air } & C-25\end{array}$

PCB's in Oil $\quad C-33$

$\begin{array}{lr}\text { Trichloroacetic Acid in Urine } & C-39\end{array}$

$\begin{array}{ll}\text { SECT ION D): (GFNFRAI, RADIOCHFMICAI, METHODS } & \text { D)-1 }\end{array}$

Enviromental Samples $\quad$ D -3

Gross Alpha and Beta Activity in Water $\quad$ D-5

Tritium in Urine and Water and on Swipes

$\begin{array}{ll}\text { Total Uranium in Soil, Urine, and Water } & \text { D)-17 }\end{array}$ 


\section{FIGURES}

A-1 Label for Industrial Hygiene Samples

A -8

A-2 Laboratory Services/Chain-of-Custody Form

$A-10$

B-1 Arsine Generator

$B-7$

\section{TABLES}

B-1 Ion Chromatographic Data for Common Anions

B -6

B-2 Atomic Absorption Parameters

B -21

B-3 Typical AA Detection Limits

$B-28$

B-4 Compressed Gas Association Specifications

$B-33$

B-5 ICP Parameters

$B-55$

C-1 Organic Solvent Parameters

D-1 Universal Decay Table

$\mathrm{C}-31$

$\mathrm{D}-13$ 


\section{SECTION A}

\section{INTRODUCTION}

○

○

○

$$
\text { A }-1
$$


THIS PAGE INTENTIONALLY LEFT BIANK

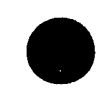

$\bullet$

$$
\text { A }-2
$$


The Industrial Hygiene Chemistry Laboratory is operated in such a manner to insure the protection of both the environment and the laboratory staff. The guidelines are specified in the Corporate Chemical Hygiene Plan and in Activity-Specific ES\&H Standard operating Procedure (SOP) SP471521, Operation of the Industrial Hygiene Chemistry Laboratory (Date). The SOP indicates proper storage, handling, disposal of hazardous chemicals, including flammables, highly toxic materials, and carcinogens.

CONSULT THE APPROPRIATE MATERIAL SAEETY DATA SHEET BEEORE USING HAZARDOUS MATERIALS. Warnings for particular hazards are listed in the individual procedures. Hazard terms used in the ES\&H NOTES include the following:

ACGIH - American Conference of Governmental \& Industrial Hygienists

$$
\begin{aligned}
& \text { A1 - Confirmed human carcinogen } \\
& \text { A2 - Suspected human carcinogen }
\end{aligned}
$$

IARC - Internal Agency for Research on Cancer

1 - Carcinogenic to humans

$2 A$ - Probably carcinogenic to humans

$2 B$ - Possibly carcinogenic to humans

NTP - National Toxicology Program. 


\section{POL ICY}

The purpose of sampling and analysis is to obtain valid data, describing a particular situation, which can be interreted as a basis for possible action. Therefore the chemistry iab - field group interface must be carried out with a clear purpose and with an understanding of both the problem to be solved and the phisical conditions tha exist.

\section{SAMPLING STRATEGY}

1. Before taking any samples, especially using a new sampling procedure, contact the laboratory staff to assure that your samples will meet the requirements of the analytical technique. Among the topics that need to be discussed are the following:

a. Whether they can be run at all. If we do not currently have an appropriate technique, we may need time to develop and validate a new procedure and to acquire necessary standards.

b. Whether they can be run within the required holding time limit

c. The appropriate sampling techniques, containers, and quantities required (very important)

d. Apparatus and reagents needed for each analyte and matrix

e. Collection techniques and appropriate handling of samples to prevent contamination or loss of analyte

f. The prescribed preservation techniques.

g. Interfererces with the analytical method

h. Range and sensitivity of the analytical method.

2. When untrained people are allowed to take samples, the value of the data comes into question unless we can be sure the samples were properly taken, prepared, stored, and recorded.

3. Place sealing tape around the joints of air filter cassettes to prevent leaks.

4. SKC recommends that the openings of a charcoal tube be about one-half the tube diameter. 
5. Include at least one blank when submitting air filters, swipes, charcoal badges, or sorption tubes. The blanks not be assigned a field log number. They may simply be placed in a container (paper or plastic envelope, etc.) and labeled "Blank."

6. When requesting analysis of a mixture (such as stoddard solvent, naphthas, cleaning compounds, etc.), submit a bulk sample to permit location and standardization of peaks.

7. Eor sample submitters who have other regular sample providers, assure that they understand the rules for sample submission and that they have a supply of labels, seals, and forms. Someone must assign an appropriate identification number and maintain the field records.

8. Samples that cannot be analyzed in our laboratory may be sent out to a contract analytical lab. If we need analyses for materials other than those currently assigned, a new contract will have to be placed; so leave plenty of time. All samples sent to contract labs must go through the Industrial Hygiene Lab, where they will be assigned a lab log number, be logged into the sample data system, and be accompanied by completed chain-of-custody and laboratory request forms for the appropriate contract lab. 


\section{CHAIN-OE-CUSTODY PROCEDURES FOR SAMPLES SUBMITTED TO THE INDUSTRIAL HYGIENE CHEMISTRY LABORATORY}

\section{INTRODUCTION}

Good analytical practices, as well as potential legal problems, suggest the need for ensuring the integrity of industrial hygiene and environmental samples collected for Sandia National Laboratories, Albuquerque, and analyzed in the Industrial Hygiene Chemistry Laboratory. "Chain-of-custody" procedures allow one to trace the possession and handling of samples from the time of collection through analysis and final disposition.

Three important components of any chain-of-custody program are: 1) sample seals/labels, 2) chain-of-custody records, and 3) sample analysis request sheets. Samples may be considered secure if they are: 1) in the physical possession of an individual, 2) locked in an area of limited access, or 3) closed with a seal which must be broken when the container is opened.

The procedures discussed below will be followed for all samples submitted for analysis to the Industrial Hygiene Chemistry Laboratory. The forms and recommendations are based on those described in Reference 1.

\section{SAMPLE SEALS/LABELS}

All samples submitted to the Industrial Hygiene Laboratory must be sealed and labeled. The label may serve as the seal, if appropriately applied. Each label should contain, at a minimum, the following information:

Sample number/identification

Name and organization of the collector

Date of collection

Place of collection.

Figure $A-1$ is a copy of the labels available from the Laboratory. Others are acceptable as long as they contain the necessary information.

The seals/labels should be placed on the sample container at the time of collection. The information included on the label should also be recorded in a field log book, along with any other pertinent data required by the collector. Sample numbers should be unique and may include the collector's initials plus a 


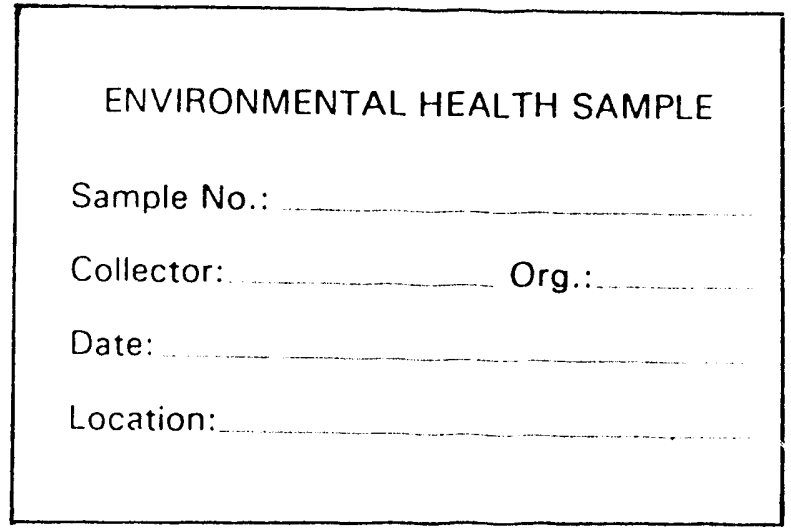

EIGURE A-1. LABEL FOR INDUSTRIAL HYGIENE SAMPLES

$$
\text { A- } 8
$$


number that will not be repeated within the foreseeable future. (That is, do not label two series of samples $x \times x 1, x \times x 2, x \times x 3$, etc.; rather, make the numbers for the two series continuous.) Alternatively, continuous field log numbers may be used. Do not repeat fiel'l log numbers thie next year.

\section{CHAIN-OE-CUSTODY RECORDS}

Sample possession must be traceable from the time of collection to the time of disposal. Traceability will be ensured by a Chain-of-Custody record which must accompany every sample submitted to the Lab for analysis. As illustrated in Figure A-2, a Chain-of-Custody form is included with the Laboratory Services form. If, in addition, the submitting organization has its own chain-of-custody document, this form should also be supplied with the sample. As indicated in the Figure, the following information must be included:

Field log number/sample description

Signatures of all people involved in the chain of possession, including the collector, deliverer, and chemist. If the person submitting the sample did not collect it, the collector's signature must be on the sheet.

Inclusive dates of possession

Final disposition of the sample.

Because the form must be signed upon receipt of the sample, samples must be given to one of the laboratory staff, not merely left in the sample prep room. If the Laboratory chemists are gone, the collector must retain possession of the samples. The original Chain-of-Custody form will be maintained in the analytical lab files, and a copy will be returned to the sample supplier for inclusion in his/her files.

\section{REQUEST EOR ANALYSIS}

When submitting samples to the Industrial Hygiene Laboratory for analysis, the sample supplier must complete a Laboratory Services form (see Figure A-2). The form includes the following information:

Name and organization of the sample supplier

Date sample was submitted

Reference employee and organization 
INDUSTRIAL HYGIENE CHEMISTRY LAB SERVICES

Laboratory Services/Chain of Custody Form

Page _... of

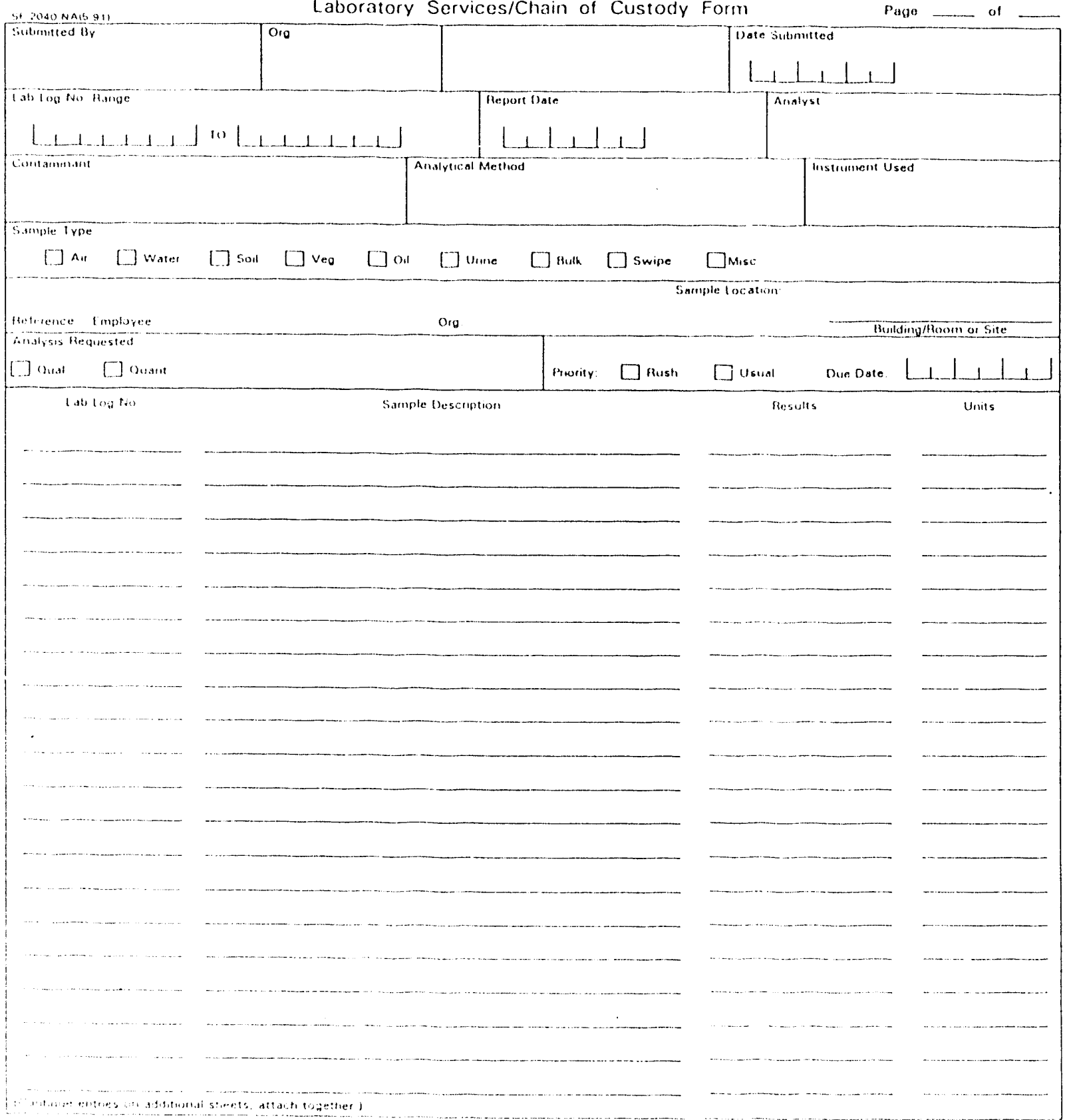

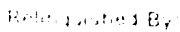

O.4t:: 1, $11 \cdots$

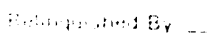

B.11.: Hirn:

R.t. enved 8

Ro. and By

D.:16:7141:

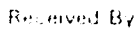

Date: / Tm

and int.....

Dingu, all $\mathrm{b}^{2}$

Dite/ 1 tmo

$0.540: 11 \cdots$

$\therefore: \cdots, \cdots:$ is,

(ti:? lat 
Location sample was taken

Contaminant to be analyzed

Laboratory $\log$ number.

In addition, for air samples always include the sampling time and rate or the total volume sampled. This information can help us decide what technique to use for the analysis. Some description, even a brief one, should be included with the Field ID number. Important information includes the person who was monitored (air samples), the approximate area sampled (swipes), and other elements or compounds coexisting with the desired analyte in your sample (because these may cause interferences with the analytical technique).

Samples, with the completed Laboratory Services/Chain-of-Custody forms, will be given to one of the analytical chemists, who will inspect the sample seals and reject any sample having a breached seal, or no seal. He will also assign unique laboratory log numbers to each sample to assure that samples and analytical results are properly correlated. A separate number will be assigned for each individual analysis requested for a given sample. Eor that reason, only one analyte per form is permitted.

Complete the "Reference" portion of the Laboratory Services form with the name of an employee in the area sampled and the location where the sample was taken (not the office of the referenced employee or sample supplier). This will facilitate data searches on the records computer.

Disposal instructions may be included by the sample supplier. If no instructions are provided, the chemist will note the final disposition of the sample on the form.

\section{REEERENCES}

1. Test Methods for Evaluating Solid Waste, Physical/Chemical Methods, Publication No. SW-846 (3rd ed;Washington, DC: U.S. Environmental Protection Agency, 1986). 


\section{INTRODUCTION}

Because of the importance of laboratory analyses and the resulting actions which they produce, a program to insure the reliability of the data is essential. All analysts practice quality control to varying degrees, depending upon their training, professional pride, and awareness of the importance of the work they are doing. However, under the pressure of daily workload, analytical quality control may be inadvertently neglected. Therefore an established routine control program, applied to every analytical test, is important in assuring the quality of the final results. The following program is designed to measure the Quality Control (QC) of the Industrial Hygiene Chemistry Laboratory.

\section{RESPONSIBILITIES}

1. Laboratory QC data will be maintained along with sample results.

2. Standards and a blank will be analyzed with every series of samples.

3. Spiked samples may be used whenever appropriate and sample size permits. When possible, a spiked blank filter will be analyzed. When running urine or water samples, an aliquot of every tenth sample may be spiked and analyzed with the sample series.

4. Each analyst will (a) routinely check, calibrate, and maintain equipment and instruments in good working order; (b) routinely check procedures and reagents; and (c) maintain good housekeeping practices, cleanliness of the work areas, and general orderliness.

\section{CONTROL CHARTS}

Control charts are compiled for each of the applicable determinations. These include:

1. Percent recoveries of all spiked and commercial control samples

2. Tritium blank in cpm and Efficiency of the tritium standard

3. Uranium standard of $0.01,0.1,1$, and 10 PPM

4. Arsenic at 10 PPM absorbance for flame AA

5. Beryllium at 1 PPM absorbance for flame AA

6. Cadmium at 1 PPM absorbance for flame AA 
7. Copper at 5 PPM absorbance for flame $A A$

8. Iron at 10 PPM absorbance for flame $A A$

9. Lead at 10 PPM absorbance for $f l a m e A A$ and 10 PPB peak height for graphite furnace

10. Lithium at 1 PPM absorbance for flame $A A$

11. Manganese at 5 PPM absorbance for flame AA

12. Nickel at 5 PPM absorbance for flame $A A$

13. Zinc at 1 PPM absorbance for flame AA

14. $\mathrm{pH} 7$ buffer

15. Specific conductivity of $1413 \mu \mathrm{mho} / \mathrm{cm}$ standard

\section{LOG BOOKS}

Permanent logbooks or records are kept to document the following procedures:

Preparation of calibration standards and reagents

Calibration of gravimetric and volumetric equipment

Repair and preventive maintenance of analytical instruments.

\section{INTERLABORATORY REEERENCE SYSTEMS}

The analytical laboratory participates in interlaboratory intercomparison studies whenever possible. The current programs are:

1. The AIHA/NIOSH Proficiency Analytical Testing (PAT) program

2. The EPA-sponsored Radioactive cross-check program, run occasionally in cooperation with Division 3213, Health Instrumentation

3. The DOE/EML-sponsored Radioactive environmental study, run occasionally in cooperation with Division 3213, Health Instrumentation. 


\section{SECTION B}

\section{INORGANIC METHODS}

$$
\text { B-1 }
$$


THIS PAGE INTENTIONALLY LEFT BLANK

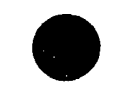

$B-2$ 


\section{COMMON ANIONS IN AQUEOUS SOLUTIONS}

\section{ABSTRACT}

Ion chromatography is a low-pressure, high-performance, liquidchromatographic technique for the determination of ions by separation on a low capacity ion exchange column. The sample is delivered by a stream of flowing eluent to the top of a separator column, where separation occurs based on the relative affinities of the ions for the functional group of the column packing. The separated ion bands then pass through a suppressor column having a functional group with a charge opposite to that of the separator packing. This column neutralizes the eluent ions to suppress their conductivity and enhances the conductivity of the analyte ions, thus improving the sensitivity.

Anions of strong acids can be detected easily using a conductivity detector. Retention times and detection limits for several common anions are listed in Table B-1.*

\section{APPLICATIONS AND LIMITATIONS}

Ion chromatography is a fairly rapid, highly sensitive technique, having a precision of $1-5 \%$ at low concentrations between 10 PPB and 100 PPM. Calibration is often linear over 4 orders of magnitude. The equipment is relatively inexpensive, and the technique usually requires little or no sample preparation for clean samples or even those containing large quantities of salts (brines, etc.).

The main disadvantages are as follows: (1) Because the conductivity detector responds to any anion, identification relies upon retention time. (2) Interferences sometimes limit the number of anions that can be analyzed in a single run. (3) Procedures often must be adjusted to achieve adequate separations. These disadvantages are common to all forms of chromatography.

\section{APPARATUS}

Ion chromatograph, Dionex Model $2110 \mathrm{i}$ with conductivity detector

Integrator, Hewlett-Packard Model $3390 \mathrm{~A}$ or $3396 \mathrm{~A}$

Syringes, $5 \mathrm{cc}$, plastic

* Retention time is influenced by flow rate, pressure, and age of column. Times in Table B-1 are based on a flow rate of 138 $\mathrm{ml} / \mathrm{hr}$. See Reference 3 . 


\section{REAGENTS}

Eluent solution, $0.0029 \mathrm{M} \mathrm{NaHCO} / 0.0023 \mathrm{M}_{3} \mathrm{Na}_{2} \mathrm{CO}_{3}-$ Dissolve $0.9744 \pm 0.0005 \mathrm{~g}$ of $\mathrm{NaHCO}_{3}$ and $0.9752 \pm 0.0005 \mathrm{~g}$ of $\mathrm{Na}_{2} \mathrm{CO}_{3}$ in 4 liters of distilled water.

Regenerant solution, $0.025 \mathrm{~N}_{2} \mathrm{SO}_{4}-$ Dilute $2.8 \mathrm{ml}$ of concentrated $\mathrm{H}_{2} \mathrm{SO}_{4}$ to 4 liters with distilled water.

\section{ANALYTICAL PROCEDURE}

1. Conditions:
a. Separator column: Dionex HPIC-AS4 anion exchange column, $3 \times 500 \mathrm{~mm}$
b. Suppressor column: Dionex AES (anion fiber suppressor)
Low pressure limit 0 psi
Elow rate $2 \mathrm{ml} / \mathrm{min}$
c. Flow settings: High pressure limit 1500 psi

2. Turn on the air to the pneumatic valves, the power to the chromatograph, the regenerant flow, and the eluent flow.

3. Press the START button, and watch the pressure rise. If the pressure rises to the maximum, the system is ready to run. If it stays low, the pump probably needs priming with ethanol (see Reference 4). If the back pressure rises high enough to shut down the system, replace the pre-filter.

4. When the READY light comes on, turn on CELL and AUTO OFFSET; and wait for the conductivity reading to stabilize. With AUTO OFESET turned off, the reading should be $\leq 25$ for this eluent. When AUTO OFESET is on, it cancels out the baseline and should be stable at $<0.1$.

5. Draw about $5 \mathrm{ml}$ of sample into a plastic syringe, and attach it to Sample Port 1. Inject about $1 \mathrm{ml}$ of sample, excluding any bubbles, until liquid exits the tubing on the front of the instrument.

6. Set the integrator parameters to the values listed in the Integrator Quick Reference Guide (Reference 5).

7. Reset the AUTO CEFSET to zero; then push the SYS 1 INJECT Button and the integrator START Button simultaneously. The anion run requires about 20 minutes to complete. 
8. Peaks are identified by their approximate retention times. For each peak, the integrator lists retention time, area, area-to-height ratio, and percent area. In addition, it draws a chromatogram of the run.

9. For quantitative results, run appropriate standards and prepare calibration graphs of peak area versus concentration.

10. After the last run, inject distilled water and run for 30 minutes to purge the exchange system before shutting down.

\section{REEERENCES}

1. J.S. Eritz, "Ion Chromatography," Anal Chem 59(4):335A (1987).

2. D.'T.E. Hunt and A.L. Wilson, The Chemical Analysis of Water (2nd ed; Loridon: The Royal Society of Chemistry, 1986), p. 489 .

3. Ion Chromatography Training Course (Sunnyvale, CA: Dionex Corp., 1978).

4. Series 2000i Operations Manual (Sunnyvale, CA: Dionex Corp., $1978)$.

5. 3390A Reporting Integrator Quick Reference Guide, Publication No. 03390-90004 (Avondale, PA: Heivlett-Packard, $1980)$.

Reviewed by:

Reviewed by:

Reviewed by:

Reviewed by:

Reviewed by:
Review date:

Review date:

Review date:

Review date:

Review date: 
TABLE B-1

ION CHROMATOGRAPHIC DATA FOR COMMON ANIONS

\begin{tabular}{|l|c|c|}
\hline ANION & RETENTION & $\begin{array}{c}\text { METHOD DETECTION } \\
\text { TIMIT, mg/L }\end{array}$ \\
\hline $\mathrm{E}^{-}$ & 2 & 0.05 \\
Acetate & 2 & 0.1 \\
Eormate & 3 & 0.1 \\
$\mathrm{Cl}^{-}$ & 3 & 0.07 \\
$\mathrm{NO}_{2}^{-}$ & 4 & 0.5 \\
$\mathrm{PO}_{4}^{-3}$ & 8 & 0.2 \\
$\mathrm{Br}^{-}$ & 9 & 0.5 \\
$\mathrm{NO}_{3}^{-}$ & 14 & 0.3 \\
$\mathrm{SO}_{4}^{-2}$ & 18 & 0.1 \\
$\mathrm{Oxa}^{-2}$ & 20 & 0.5 \\
\hline
\end{tabular}




\section{ABSTRACT}

Ashed samples are reduced to trivalent arsenic, evolved as arsine gas, and collected in silver diethyldithiocarbamate which is then determined colorimetrically at $560 \mathrm{~nm}$.

\section{ES\&H NOTES}

Inorganic arsenic and many of its compounds are designated as NTP known human carcinogens and as Class 1 carcinogens by the IARC. They are also moderately to highly toxic. These materials should be handled in a Designated Area, typically a laboratory hood. The room and/or hood shall be clearly labeled with a sign indicating that a carcinogen is in use.

\section{APPARATUS}

Spectrophotometer, Hewlett-Packard Model $8450 \mathrm{~A}$ or equivalent with $1-\mathrm{cm}$ cells

Arsine generator (Eigure B-1)

$A=$ Generator flask

$B=$ Scrubber with glass wool plug of lead acetate

$C=$ Evolution tube

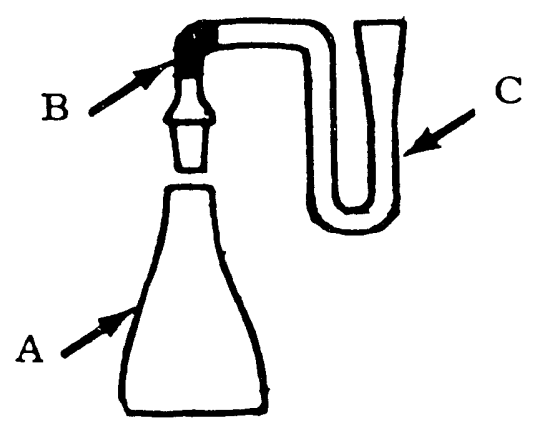

Eigure B-1. Arsine Generator

\section{REAGENTS}

Nitric acid, conc. $\left(70 \% \mathrm{HNO}_{3}\right)$

Perchloric acid, conc. $\left(70 \% \mathrm{HClO}_{4}\right)$

Sulfuric acid, conc. $\left(96 \% \mathrm{H}_{2} \mathrm{SO}_{4}\right)$

Acid digestion mixture II, $3: 1: 1$ conc. $\mathrm{HNO}_{3}$ : conc. $\mathrm{H}_{2} \mathrm{SO}_{4}$ :

conc. $\mathrm{HClO}_{4}$

Ammonium oxalate, saturated solution

Hydrochloric acid, conc. (36\% HCl) 


\section{Silver diethyldithiocarbamate}

Pyridine

Arsine absorbing solution - Dissolve $1 \mathrm{~g}$ of silver diethyldithiocarbamate in $200 \mathrm{ml}$ of A.R. pyridine. the solution before use. Store in a brown bottle.

Filter

Potassium iodide solution - Dissolve $15 \mathrm{~g}$ of $\mathrm{KI}$ in $100 \mathrm{ml}$ of water. Store in a brown bottle.

Stannous chloride solution - Dissolve $40 \mathrm{~g}$ of stannous chloride dihydrate in $100 \mathrm{ml}$ of conc. $\mathrm{HCl}$.

Lead acetate solution - Dissolve $10 \mathrm{~g}$ of lead acetate in 100 $\mathrm{ml}$ of water. Glass wool in the scrubber is soaked in this solution, drained, and dried.

Zinc, granular 20 mesh

Arsenic standard solution $(1 \mathrm{mg} / \mathrm{ml})$ - Dissolve $0.660 \mathrm{~g}$ of $\mathrm{As}_{2} \mathrm{O}_{3}$ in $10 \mathrm{ml}$ of $20 \% \mathrm{NaOH}$, then dilute to $500 \mathrm{ml}$. CAUTION: THIS SOLUTION IS TOXIC!

\section{ANALYTICAL PROCEDURE}

1. Transfer the filter paper sample or $25 \mathrm{ml}$ of urine or $25 \mathrm{ml}$ of water into a 150-ml beaker.

2. Ash the sample using 5-10 $\mathrm{ml}$ of digestion mixture II, and heat on a $140^{\circ} \mathrm{C}$ hot plate. Continue heating to white fumes of $\mathrm{SO}_{3}$.

3. Cool; add $10 \mathrm{ml}$ of distilled water and $5 \mathrm{ml}$ of a saturated solution of ammonium oxalate; and again heat to fumes of $\mathrm{SO}_{3}$ to remove all traces of nitric acid.

4. Cool, add $10 \mathrm{ml}$ of conc. $\mathrm{HCl}$, and quantitatively transfer with distilled water to a 50-ml graduated cylinder.

5. Transfer a 25-ml aliquot to the generator flask.

6. To the evolution tube add $3 \mathrm{ml}$ of the pyridine-silver diethyldithiocarbamate absorbing solution.

7. To the sample solution in the generator flask add $2 \mathrm{ml}$ of $15 \% \mathrm{KI}$ and swirl to $\mathrm{mix}$. Add $0.5 \mathrm{ml}$ of $40 \% \mathrm{SnCl}_{2}$, swirl to mix, and allow to stand for 15 minutes to reduce the arsenic to the trivalent form.

8. Add to the generator flask $7 \mathrm{~g}$ of $\mathrm{zinc}$, and close the flask immediately. 
9. Heat the flask in a beaker of hot tap water, and allow the reaction to proceed for 30 minutes. A soluble red complex should form.

10. Transfer the arsine absorbing solution to a $1-\mathrm{cm}$ cell, and read the absorbance at $560 \mathrm{~nm}$, using unreacted silver diethyldithiocarbamate as a blank.

11. Prepare working standards in the range of $1-20 \mu \mathrm{g} / \mathrm{ml}$ arsenic from the stock standard.

12. Pipet $1 \mathrm{ml}$ of each working standard into arsine generators, add $20 \mathrm{ml}$ of distilled water and $5 \mathrm{ml} \mathrm{HCl}$, and proceed with step 6 of the procedure.

13. Draw a calibration curve of absorbance versus $\mu g$ As, and use it to determine the arsenic content of the samples.

\section{CALCULATIONS}

$\begin{aligned} \text { mg As } / \text { L urine } & =\frac{\mu g \text { As (from curve) }}{\mathrm{ml} \text { of urine }} \\ \mathrm{mg} \mathrm{As} / \mathrm{L} \text { water } & =\frac{\mu g \text { As }}{\mathrm{ml} \text { of water }} \\ \mathrm{mg} \mathrm{As} / \mathrm{m}^{3} & \frac{\mathrm{mg} \mathrm{As}}{\mathrm{m}^{3} \text { of air sampled at STP }} \\ & =\frac{\mu \mathrm{\mu g} \text { As }}{\text { liters of air sampled at STP }}\end{aligned}$

\section{REEERENCES}

1. Standard Methods for the Examination of Water and Wastewater (16th ed; Washington, DC: American Public Health Association, 1985), p. 187.

2. J.L. Monkman, "Determination of Arsenic in Air," Analytical Methods Manual (Cincinnati, OH: American Conference of Government Industrial Hygienists, 1958).

Reviewed by:

Reviewed by:

Reviewed by:

Reviewed by:

Reviewed by:
Review date:
Review date:
Review date:
Review date:
Review date: 


\section{THIS PAGE INTENTIONALLY LEFT BLANK}

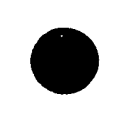




\begin{abstract}
Asbestos is defined as one of a group of fibrous, hydrated mineral silicates, consisting of three main types: chrysotile, a magnesium silicate which makes up 90-95\% of the asbestos used in industry; amosite, a magnesium/iron silicate; and

crocidolite, a sodium/iron silicate. The material was widely used for insulation and reinforcement in years past, but is currently considered a serious respiratory health hazard and potential carcinogen. For that reason, samples are prepared in a HEPA-filtered workstation.

Polarized light microscopy (PLM) is used to identify the presence of asbestos fibers in bulk samples. Initial samples should consist of a core through the cross section of the material being sampled.
\end{abstract}

\title{
APPLICATIONS AND LIMITATIONS
}

The advantages of polarized light microscopy in the identification of asbestos fibers are (1) that the technique is very sensitive (parts-per-million range); (2) that it is fairly rapid, requiring only $1-5$ minutes to complete; and (3) that individual types of asbestos can be identified, using supplementary techniques (see Reference 1).

The disadvantages include (1) that, in order to be seen, the particles must be at least $0.5 \mu \mathrm{m}$ in the smallest direction; and (2) that the analyst needs more competence and experience in this technique than in many others. The first disadvantage is mitigated somewhat by the fact that hazardous particles are defined as those having the following characteristics: length $>5 \mu \mathrm{m}$, diameter $<3 \mu \mathrm{m}$, and aspect ratio (length: width) $>5: 1$. Thus, particles not visible by PLM are believed to be relatively hàrmless.

One additional limitation to the technique is the presence of non-asbestos fibers in many insulation materials. The fibers found in most insulating materials have the following characteristics:

Asbetos

Eiberglass/glass wool

Mineral wool

Cellulose/wood/paper

Metal fragments
Straight bundles or unraveled "rope" clear tubes or glassy blobs

Curled tubes

Cells and nuclei

opaque

In addition, binder materials, such as plaster of Paris, mortar, cement, or gypsum, can obscure the presence and/or identity of any fibers. 


\section{ES\&H NOTES}

Asbestos is designated as a Class AI carcinogen by the ACGIH and a Class 1 carcinogen by the IARC. Suspected asbestos-containing materials shall be prepared in a HEPA-filtered workstation. The room and/or hood shall be clearly labeled with a sign indicating that a carcinogen is in use.

\section{APPARATUS}

Polarized Light Microscope, Bausch \& Lomb

Microscope slides, glass

Tweezers and teasing needles

\section{REAGENTS}

Index of refraction liquid, Cargille High Density, certified. The preferred index of refraction is 1.552 , but either 1.550 or 1.554 is also acceptable.

\section{ANALYTICAL PROCEDURE}

1. Working in a HEPA-filtered workstation, clean a glass microscope slide; and apply a drop of Cargille index of refraction liquid.

2. Remove typical fibers from the sample, and deposit them in the liquid on the slide.

3. Mount the slide on the polarizing light microscope, turn on the illuminator, and examine the fibers. Asbestos fibers usually look like straight bundles or unraveled rope.

4. Rotate the polarizer until the background appears dark. Rotate the stage, observing the fibers for color change to red-brown or blue-green. The color change is common for asbestos, although its presence doesn't guarantee that the sample is asbestos nor does its absence guarantee that it isn't. The polarizer aiso helps blank out some of the binder materials, thus emphasizing the fibers. Reference 1 contains photomicrographs of asbestos and other associated materials, which can be used to help identify the sample. 


\section{REEERENCES}

1. W.C. McCrone, The Asbestos Particle Atlas (Ann Arbor, MI: Ann Arbor Science, 1980).

2. Asbestos-Containing Materials in School Buildings: A Guidance Document. Part 1 (Washington, DC: U.S. Environmental Protection Agency, 1979).

3. M. Cossette, "Defining Asbestos Particulates for Monitoring Purposes," Definitions for Asbestos and Other Health-Related Silicates, ASTM Publication 834, ed B. Levadie (Philadelphia: American Society for Testing and Materials, $1984)$, p. 5.

4. "Asbestos (Bulk)," NIOSH Manual of Analytical Methods, Vol. 1, U.S. Department of Health and Human Services Publication No. 84-100, ed P.M. Eller (3rd ed; Washington, DC: U.S. Government Printing Office, 1984), Method 9002 .

Reviewed by:

Reviewed by:

Reviewed by:

Reviewed by:

Reviewed by:
Review date:

Review date:

Review date:

Review date:

Review date: 
THIS PAGE INTENTIONALLY LEFT BLANK
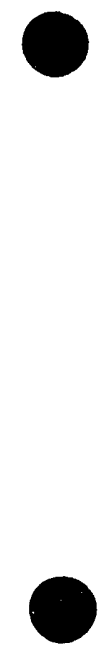


\section{GENERAL PROCEDURES EOR ATOMIC ABSORPTION SPECTROSCOPY}

\section{ABSTRACT}

The atomic absorption spectrophotometer is the instrument of choice for quantitating PPM to PPB amounts of metals in air samples, biological samples, commercial products, swipes, and water. Its advantages are (1) ease of sample preparation -normally, only sample dissolution is required; (2) sensitivity - most metaliic elements are easily quantitated in the PPM to $P P B$ range; (3) selectivity - - with very rare exceptions, the sensitive lines of one element do not overlap the sensitive lines of another; and (4) minimum matrix interferences -- if present, procedures for elimination of these interferences are listed in Table $\mathrm{B}-2 . * *$

This atomic absorption section contains divisions which describe the equipment, sample preparation, reagents, data collection, and calculations. Standardization techniques closely follow the manufacturer's instructions in the AA Methods Manual. For installation, operating procedures, and safety precautions, see Reference 3 .

\section{APPLICATIONS AND LIMITATIONS}

1. The analytical working range for each metal is given in Table B-2. Higher concentrations can be determined by dilution of the sample.

2. The detection limits and interferences for each metal are given in Table B-2.

3. The coefficient of variation for the analysis is approximately $2 \%$, depending upon the instrument and the absorbance of the sample.

4. As, In, Se, $\mathrm{Te}, \mathrm{Tl}$, and $\mathrm{Hg}$ are very volatile elements and must not be heated any more than necessary in sample preparation.

\section{ES\&H NOTES}

Some of the metals determined by AA are designated as carcinogens by the ACGIH and by the IARC. These materials should be handled in a Designated Area, typically a laboratory hood, to minimize respiratory exposure. The room and/or hood shall be clearly labeled with a sign indicating that a carcinogen is in use.

** See Reference 1 , herein referred to as the AA Methods Manual. 
Because hydrofluoric acid is highly toxic and corrosive, avoid inhalation, ingestion, or contact. Wear appropriate gloves and handle in a hood. Wash skin after use to avoid potential tissue damage.

\section{APPARATUS}

Atomic absorption spectrophotometer - Perkin-Elmer Model 703 , including the necessary burner heads for air-acetylene and nitrous oxide-acetylene flames and the appropriate hollow cathode (HCL) or electrodeless discharge (EDL) lamps.

Recorder, Texas Instruments "Servo-Riter," 0-10 mv

Atomic absorption accessories - See the AA Methods Manual for Delves sampling cup, boat method, graphite furnace, flameless mercury analyzer, hydride generator, etc.

Beakers, 100 and $150 \mathrm{ml}$, with watchglass covers

Graduated cylinders, $10 \mathrm{ml}$ and $100 \mathrm{ml}$

Hot plate capable of reaching $400^{\circ} \mathrm{C}$

Platinum crucibles

Polyethylene bottles, $125 \mathrm{ml}$ and $150 \mathrm{ml}$

Teflon beakers

\section{REAGENTS}

Nitric acid, conc. $\left(70 \% \mathrm{HNO}_{3}\right)$, redistilled

Sulfuric acid, conc. $\left(96 \% \mathrm{H}_{2} \mathrm{SO}_{4}\right)$

Perchloric acid, conc. $\left(70 \% \mathrm{HClO}_{4}\right)$

Acid digestion mixture I, 8:1:1 of conc. $\mathrm{HNO}_{3}$ : conc. $\mathrm{H}_{2} \mathrm{SO}_{4}$ : conc. $\mathrm{HClO}_{4}$

Hydrochloric acid, conc. (36\% $\mathrm{HCl})$

Hydrochloric acid (6N) - Add $500 \mathrm{ml}$ of conc. HCl to $500 \mathrm{ml}$ of distilled water.

Hydrofluoric acid (48\% $\mathrm{HF}$ )

Hydrogen peroxide $\left(30 \% \mathrm{H}_{2} \mathrm{O}_{2}\right)$ 
Stock standards - Commercially prepared aqueous stock standards of $1000 \mu \mathrm{g} / \mathrm{ml}$ are available for most elements. Alternatively, make up $1000-\mu \mathrm{g} / \mathrm{ml}$ solutions of each of the elements listed in Table B-2, being sure to acidify them properly to keep the metals in solution (see Reference 4 or 5). $\mathrm{As}, \mathrm{Be}, \mathrm{Bi}$, and $\mathrm{Sb}$ are easily hydrated to their insoluble oxychiorides or hydroxides; therefore the stock solutions of these elements must be in at least $6 \mathrm{~N}$ acid. others are stable in $1 \mathrm{~N}$ acid. Keep all stock solutions in polyethylene bottles. Hg and Tl form insoluble chlorides in their lower oxidation states; therefore add $5 \mathrm{ml}$ of conc. $\mathrm{HNO}_{3}$, prior to dilution to volume, to provide an oxidizing medium and ensure their higher valence states.

Working solutions - Erom each of the $1000-\mu \mathrm{g} / \mathrm{ml}$ stock standards, prepare working standards to cover the range for each metal as given in Table $\mathrm{B}-2$. All working standards should be acidified as strongly as the stock standards and stored in polyethylene bottles. Remake the standards every day for best results. When analyzing for any of the metals with known interferences, as indicated in $\mathrm{Table} B-2$, prepare the standards according to the "Remedies" listed in the Table.

\section{SAMPLE PREPARATION}

Air samples and swipes

1. Transfer samples to beakers. Check Reference 1 for the optimum dissolution acids.

2. For most samples containing metals other than Be, add $5 \mathrm{ml}$ of conc. $\mathrm{HNO}_{3}$. Heat on a hot plate in a fume hood until the sample chars or until about $1 \mathrm{ml}$ of a colorless or light yellow solution remains. If necessary to prevent loss of sample, cover each beaker with a watchglass.

3. Cool the sample. If it remains light colored and clear, transfer it to a 10-ml graduated cylinder with distilled water. Dilute the aliquots, if necessary, or reduce the volume by evaporation to obtain a concentration within the working range of the metal.

4. If the sample is dark yellow or undissolved particulates remain, add more conc. $\mathrm{HNO}_{3}$, and continue as in step 2 . Undissolvable particulates may be allowed to settle in the graduated cyliner or may be filtered through a No. 41 filter. In addition, some metals should be heated to near dryness and redissolved in $6 \mathrm{~N} \mathrm{HCl}$ (see Reference 1). 
5. Eor samples containing BeO, add 5-10 $\mathrm{ml}$ of acid digestion mixture I. Heat the samples at $200-400^{\circ} \mathrm{C}$ until digestion is complete and white $\mathrm{SO}_{3}$ fumes are evolved. Proceed as in Step 3 .

ores, soils, and dusts

1. Ignite a $1.0000 \pm 0.005 \mathrm{~g}$ dried 200 -mesh sample in a platinum crucible at $900^{\circ} \mathrm{C}$. Cool and transfer the ignited sample to a 100-ml Teflon beaker.

2. Dissolve the sample by adding $10 \mathrm{ml}$ of $\mathrm{HF}$ and $10 \mathrm{ml}$ of $\mathrm{HCl}$, and evaporate to dryness on a low-temperature hot plate. Repeat the addition of $\mathrm{HF}$ and $\mathrm{HCl}$, and evaporate to dryness.

3. Add $5 \mathrm{ml}$ of $\mathrm{HCl}$, and evaporate to dryness. Repeat.

4. Dissolve the residue in $6 \mathrm{~N} \mathrm{HCl}$ or conc. $\mathrm{HNO}_{3}$, and quantitatively transfer it to a 100-ml graduated cylinder with distilled water. Dilute the aliquots, if necessary, to obtain metal concentrations within the working range of the method.

\section{Vegetation}

1. Place several grams of dried vegetation in a blender, and blend until the sample is thoroughly cut and mixed.

2. Place about $10 \mathrm{~g}$ in a platinum or porcelain crucible, and heat in a muffle furnace at $450^{\circ} \mathrm{C}$ until a white ash remains.

3. Continue with step 1 under Solis.

\section{Urine}

1. Add $20 \mathrm{ml}$ of conc. $\mathrm{HNO}_{3}$ and $5 \mathrm{ml}$ of $\mathrm{H}_{2} \mathrm{O}_{2}$ to a $100-\mathrm{ml}$ aliquot of urine in a 500-ml Erlenmeyer flask.

2. Evaporate to dryness; repeat the addition of conc. $\mathrm{HNO}_{3}$ until a white ash is obtained.

3. Add $5 \mathrm{ml}$ of conc. $\mathrm{HNO}_{3}$ or $6 \mathrm{~N} \mathrm{HCl}$. Warm the solution to dissolve the residue, and quantitatively transfer it to a 10- $\mathrm{ml}$ graduated cylinder.

\section{ANALYTICAL PROCEDURE}

1. Turn on the power to the atcmic absorption unit. Install the lamp to be used, and adjust the lamp current to the recommended setting. 
2. Turn on the air and the acetylene or nitrous oxide to the control box; and adjust the fuel and air flow, as indicated in the instruction Manual.

3. Install the proper burner head, according to the "type of oxidant," as listed in Table B-2.

4. Set the wavelength control to the proper analytical wavelength for the metal of interest. Adjust the GAIN to approximately two-thirds of full scale.

5. Turn on the fuel flow to the burner and ignite. Tune the burner and the nebulizer flow to maximize the absorption. Aspirnte a series of standards and the samples, and record the absorbance.

6. Prepare a calibration curve by plotting on linear graph paper the absorbance versus concentration of each standard in $\mu \mathrm{g} / \mathrm{ml}$. From the calibration curve, read the concentration $(\mu \mathrm{g} / \mathrm{ml})$ of the samples. Blank values, if any, are subracted from each sample.

7. Alternatively, calculate the concentration using the "CURVE" program on the STANDARD PAC disk for the Hewlett-Packard HP85 calculator.

\section{ALTERNATE TECHNIQUES EOR SAMPLE INTRODUCTION}

There are several alternative sample introduction techniques which can improre the sensitivity and detection limits of atomic absorption for certain elements (see Table B-3).

Hydride generation is a technique used to determine very low concentrations of elements formirg gaseous hydrides, i.e., As, $\mathrm{Bi}, \mathrm{Ge}, \mathrm{Sb}, \mathrm{Se}, \mathrm{Sn}$, and $\mathrm{Te}$. A sample reacts with sodilim borohydride to generate the gaseous hydride, which is collected until the reaction ceases. The gases are then swept into the flame, and the response is recorded on a chart recorder. Detection limits generally improve by a factor of 10 to 10,000 , depending upon the element.

The graphite furnace is a flameless sampling device providing extermely low detection limits of $10^{-10}$ to $10^{-12} \mathrm{~g}$ for most metals. In the furnace, unwanted solvent and matrix materials are vaporized first, using temperature programming, and then purged. Atomization then occurs in an inert atmosphere. Sensitivity and detection limits are improved by a factor of 100 to 1000 because of longer residence cime in the light path, eliminating the need for som a preconcentration techniques. In addition to small samples, the technique is compatible with both solid samples and those only partially dissolved. (See "Total Lead and Copper in Drinking water" and "Thallium in Urine," Seclion B of this Manual.) 


\section{CALCULATIONS}
1. Air sample: $\mathrm{mg} / \mathrm{m}^{3}=\frac{\mathrm{ml} \text { solution }}{1000} \times \frac{\mu \mathrm{g} / \mathrm{ml}}{\operatorname{vol} \text { air sample, } \mathrm{m}^{3}}$

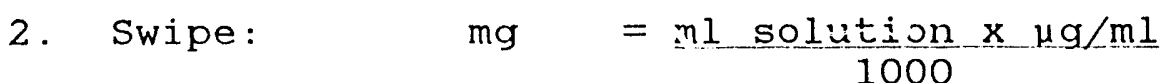
3. Liquid: $\%=\frac{\mu \mathrm{g} / \mathrm{ml}}{10,000}$

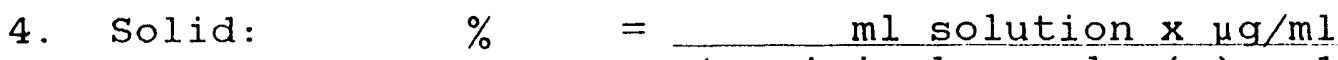
wt original sample (g) $\times 10,000$

\section{REEERENCES}

1. Analytical Methods for Atomic Absorption Spectrophotometry, Publication No. 0303-0152 (Norwalk, CT: The Perkin-Elmer Corp., 1982).

2. Analytical Methods for Atomic Absorption Spectrophotometry (Norwalk, CT: The Perkin-Elmer Corp., 1976).

3. Instructions for Model 703 Atomic Absorption Spectro shotometer, Publication No. 993-9454 (Norwalk, CT: The Perkin-Elmer Corp., 1978).

4. A.E. Ward, "Stock Standard Preparation," Jarrell-Ash Plasma Newsletter 1(2):14 (1978).

5. Techniques in Graphite Eurnace Atomic Absorption Spectrophotometry Publication No. 0993-8150 (Norwalk, CT: The Perkin-Elmer Corp., 1985).

6. Analytical Methods for Eurnace Atomic Absorption Spectroscopy, Publication No. B010-0108 (Norwalk, CT: The Perkin-Elmer Corp., 1981).

Reviewed by:

Reviewed by:

Reviewed by:

Reviewed by:

Reviewed by:
Review date:

Review date:

Review date:

Review date:

Review date: 


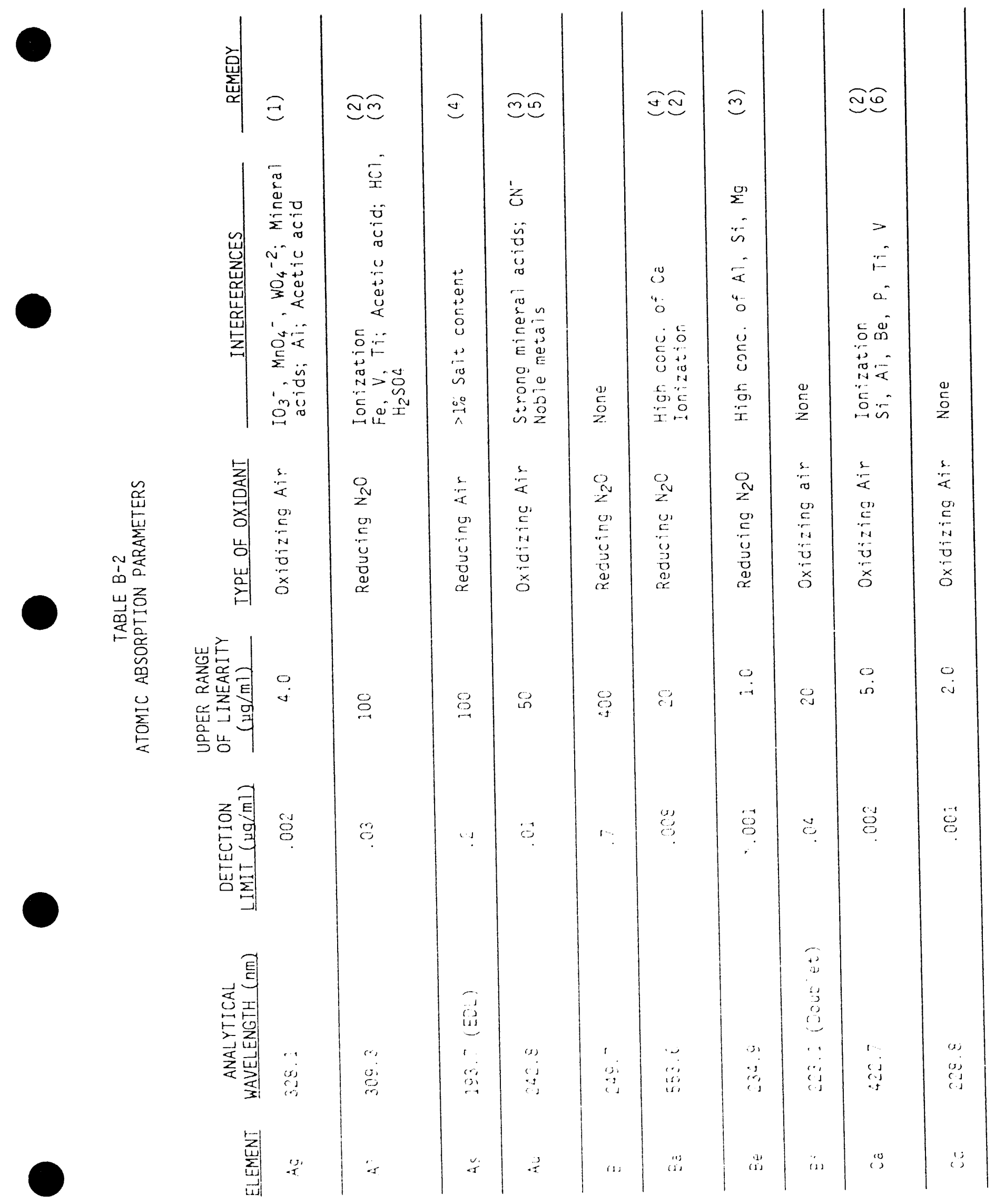




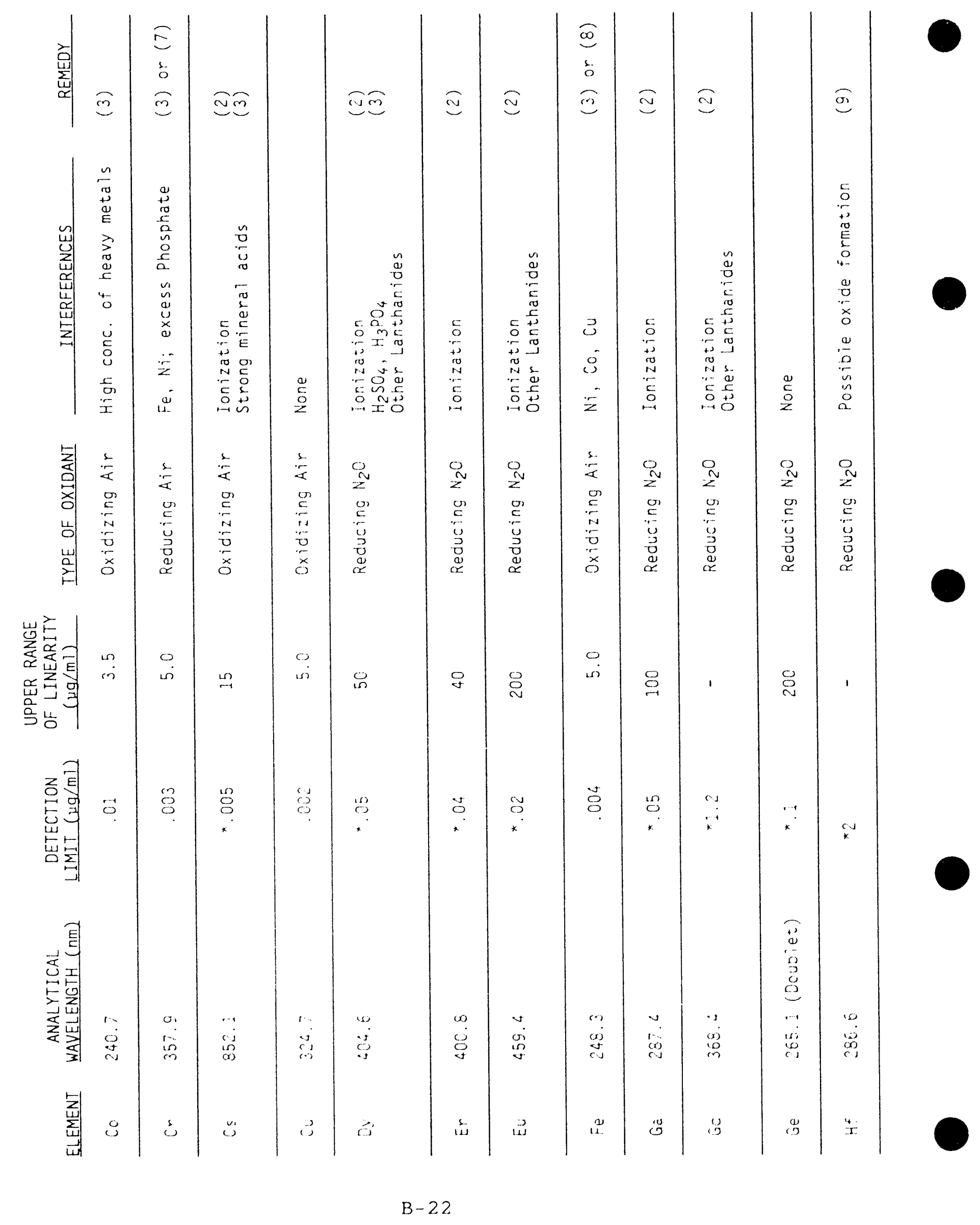




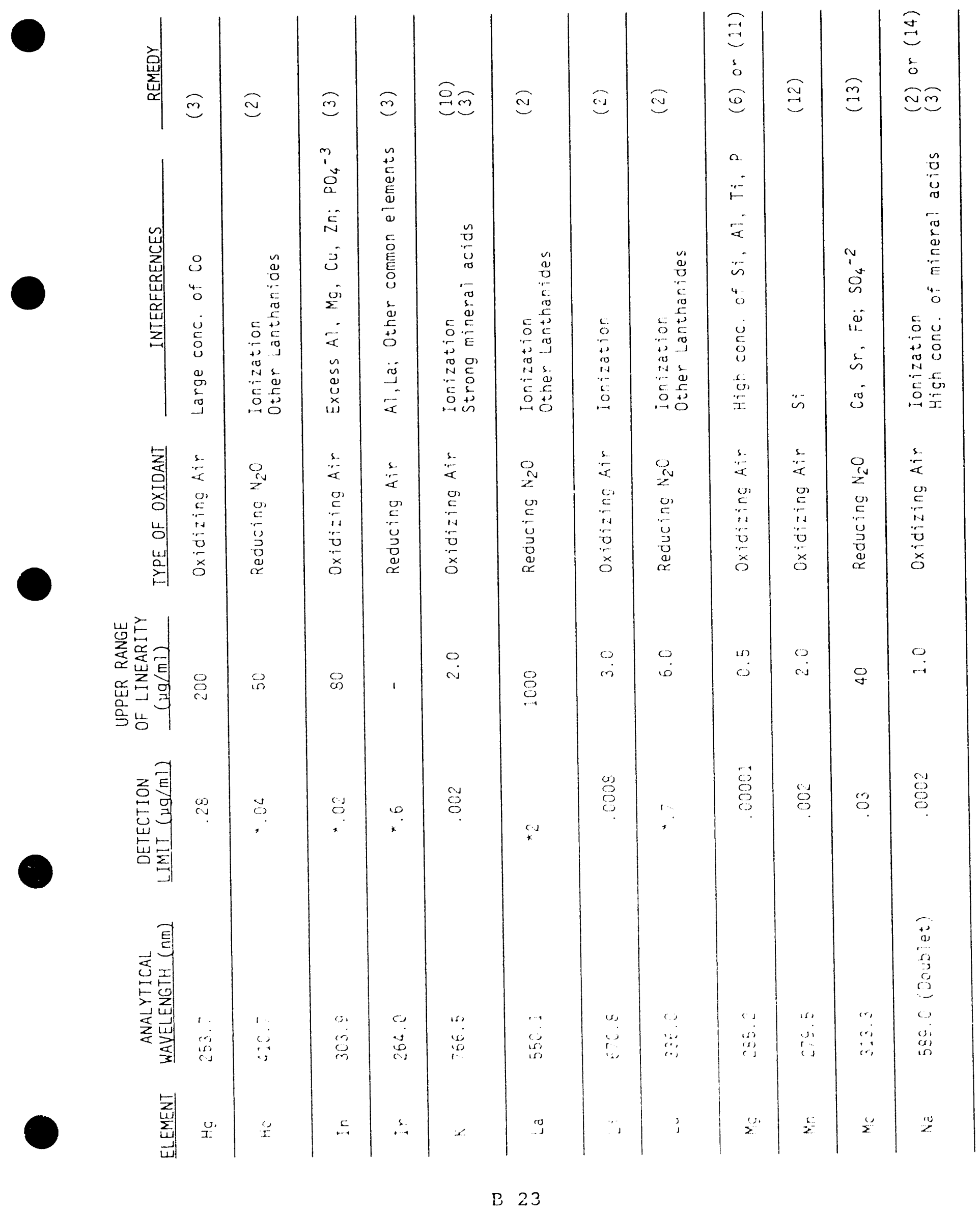




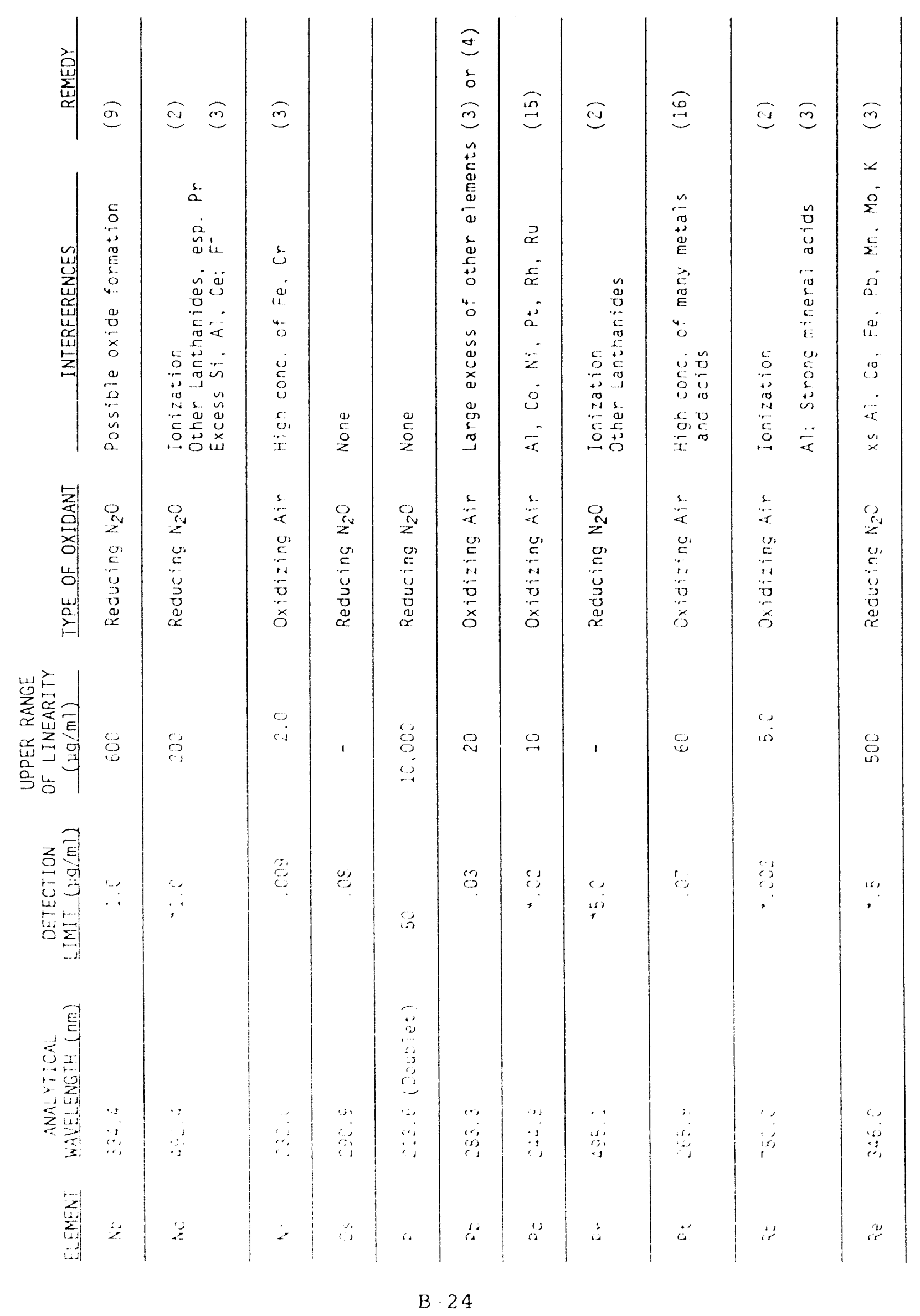




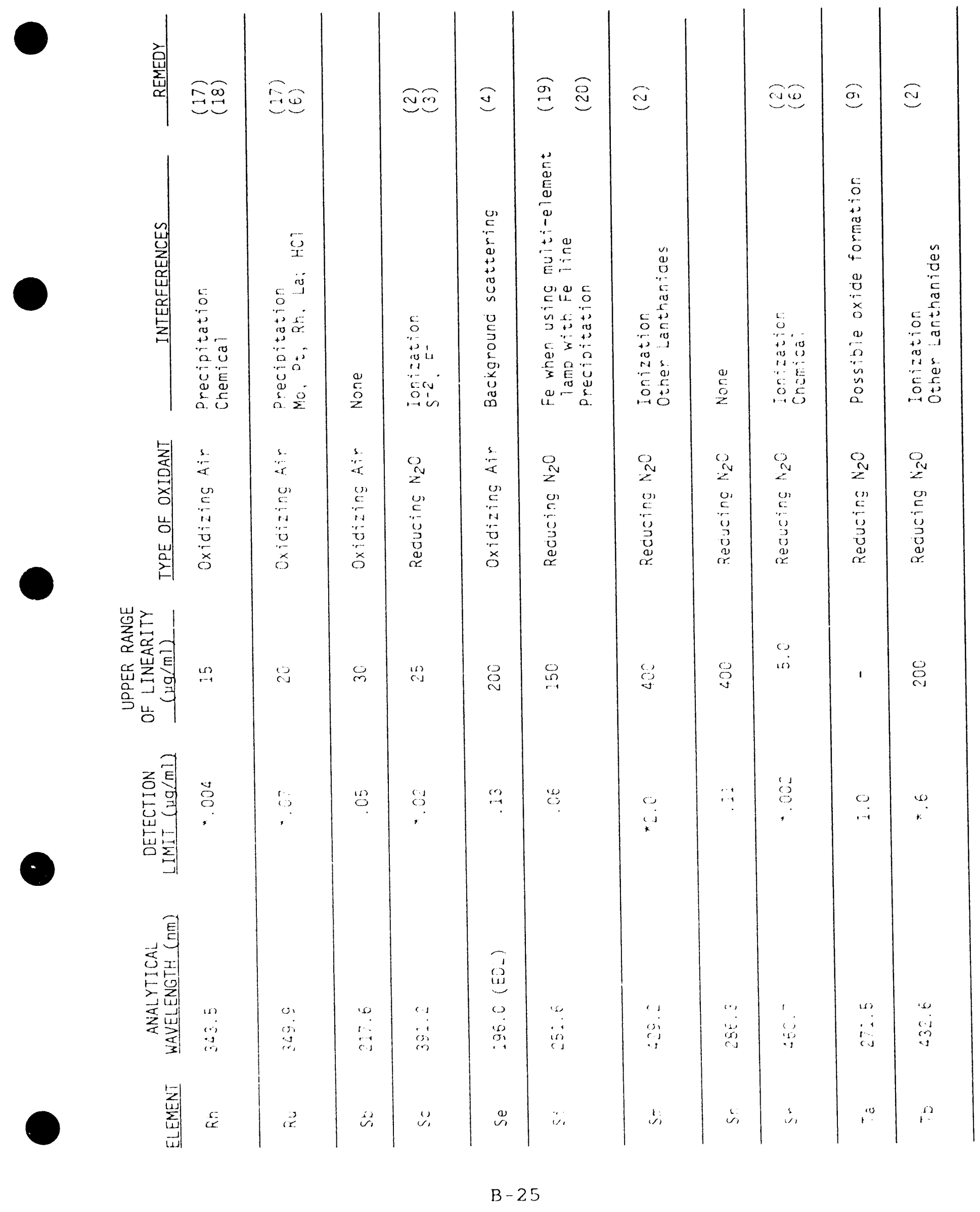




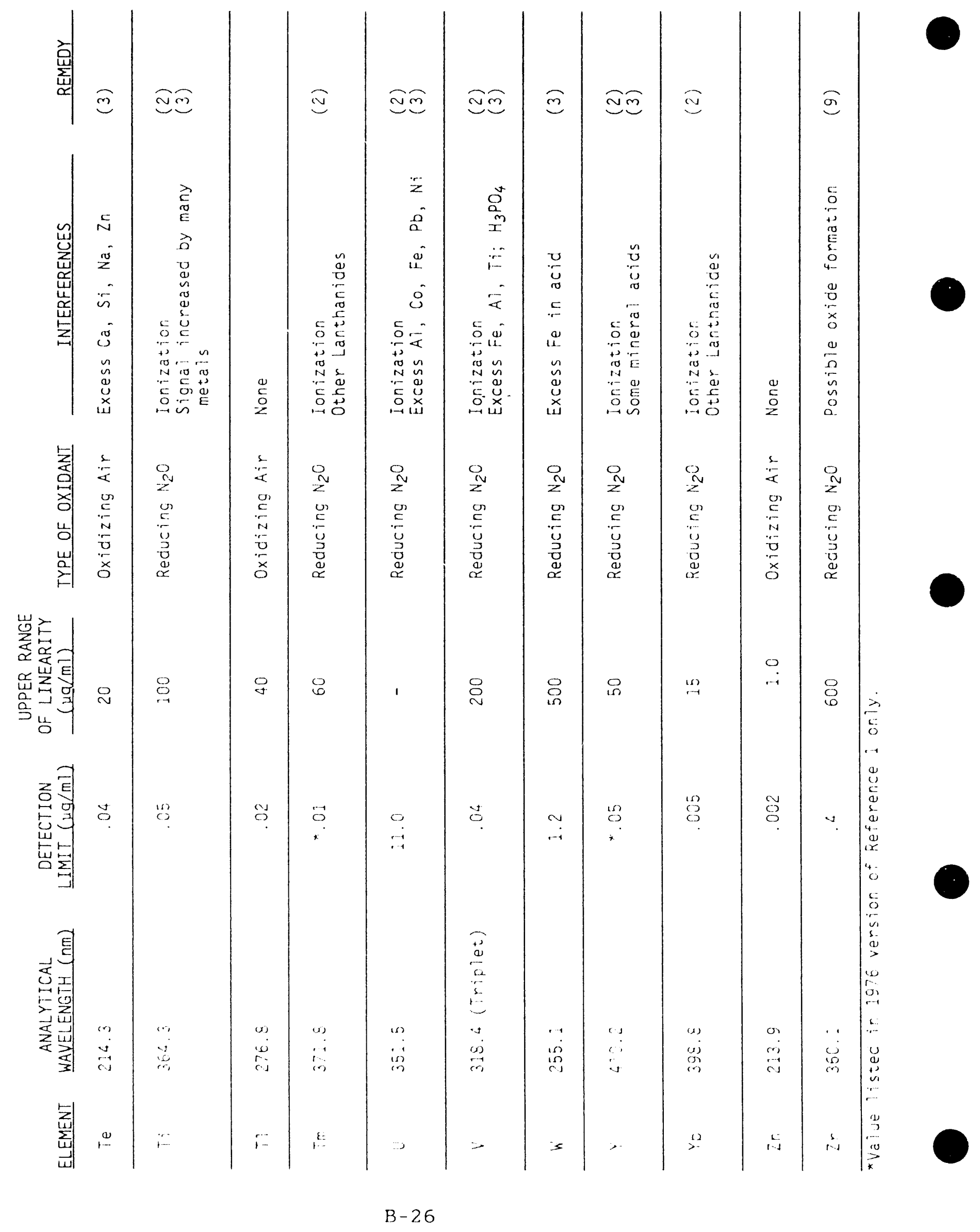




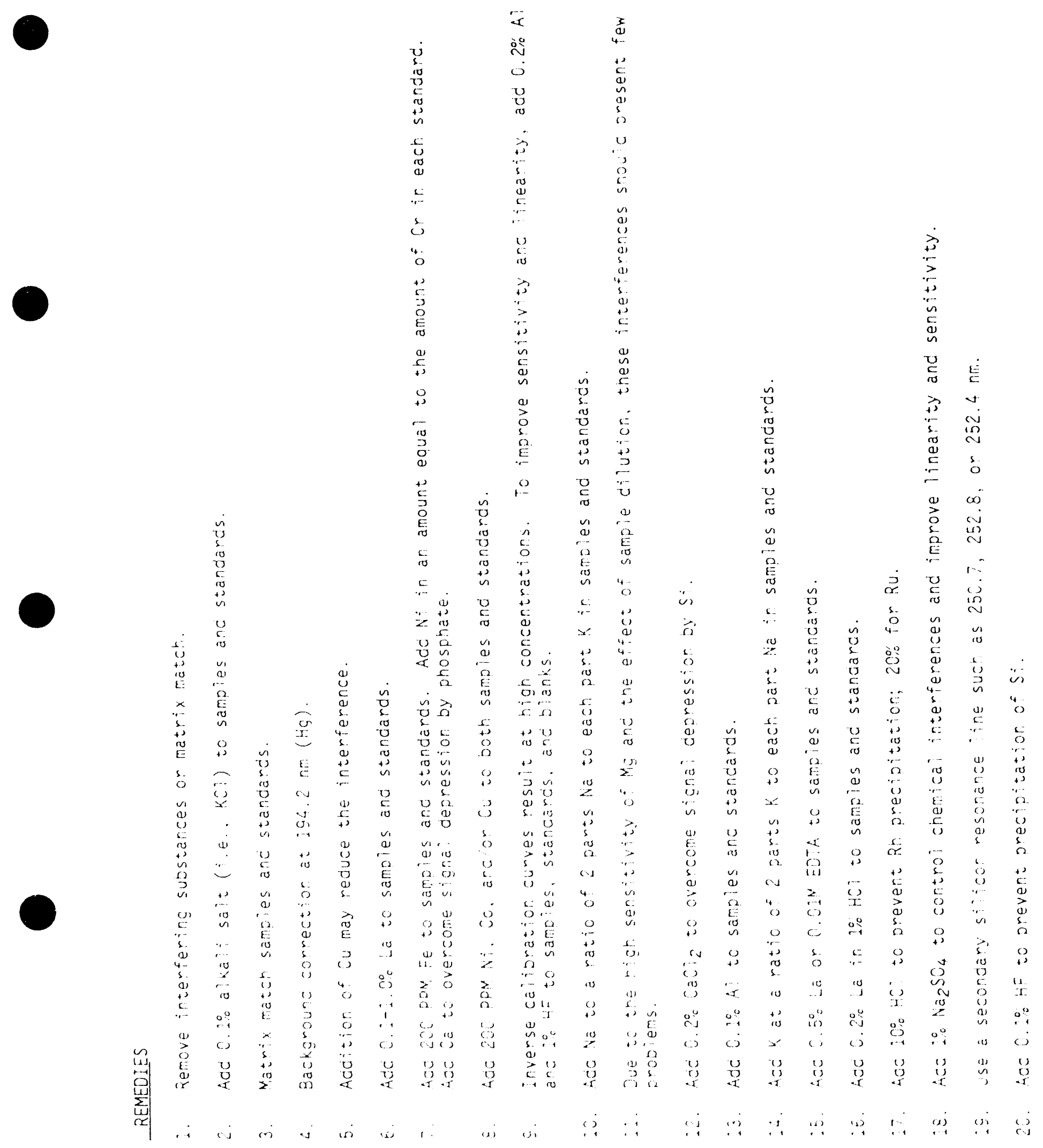


TABLE B-3

TYPICAL AA DETECTION LIMITS(a)

$(\mu \mathrm{g} / \mathrm{ml})$

\begin{tabular}{|c|c|c|c|c|}
\hline ELEMENT & ELAME AA & $\begin{array}{l}\text { GRAPHITE } \\
\text { EURNACE AA }\end{array}$ & $\begin{array}{l}\text { HYDR IDE } \\
\text { GENERATION }\end{array}$ & MICROSAMPLING (b) \\
\hline As & 0.1 & 0.0002 & 0.00002 & 0.02 \\
\hline $\mathrm{Bi}$ & 0.02 & 0.0001 & 0.00002 & 0.003 \\
\hline $\mathrm{Cd}$ & 0.005 & 0.000003 & - & 0.00005 \\
\hline $\mathrm{Ge}$ & 0.10 & - & 0.01 & - \\
\hline $\mathrm{Hg}$ & 0.2 & 0.002 & - & - \\
\hline $\mathrm{Pb}$ & 0.01 & 0.00005 & - & 0.001 \\
\hline $\mathrm{Sb}$ & 0.03 & 0.0002 & 0.0001 & - \\
\hline $\mathrm{Se}$ & 0.07 & 0.0005 & 0.00002 & 0.01 \\
\hline $\mathrm{Sn}$ & 0.1 & 0.0002 & 0.0002 & - \\
\hline $\mathrm{Te}$ & 0.02 & 0.0001 & 0.00002 & 0.01 \\
\hline $\mathrm{Tl}$ & 0.009 & 0.0001 & - & 0.001 \\
\hline $\mathrm{Zn}$ & 0.0008 & 0.000001 & - & 0.00003 \\
\hline
\end{tabular}

(a) See Reference 1

(b) See the 1976 Version of Reference 1 


\section{CHLORINE IN AIR, WATER, AND WASTEWATER}

\section{ABSTRACT}

A red color develops when DPD reacts with chlorine in acid or alkaline solutions. The maximum absorption is at $530 \mathrm{~nm}$.

\section{APPLICATIONS AND LIMITATIONS}

This method registers the total available chlorine and is rapid and simple. Bromine, iodine, ozone, and oxidized forms of manganese and chromium also may react and read as chlorine. The range is $0-1.7 \mathrm{mg} / \mathrm{L}$. Higher concentrations can be analyzed by diluting the sample.

\section{APPARATUS}

Hach colorimeter, Model DREL/5

Fritted bubbler or midget impinger, al1-glass

Assorted laboratory glassware

\section{REAGENTS}

Sodium hydroxide $(0.01 \mathrm{~N})$ - Dissolve $0.4 \mathrm{~g}$ of $\mathrm{NaOH}$ in 1 liter. of distilied water.

Sulfuric acid ( $1 \mathrm{~N})$ - Add $3 \mathrm{ml}$ of conc. $\mathrm{H}_{2} \mathrm{SO}_{4}$ to $97 \mathrm{ml}$ of water.

Hach DPD Total Chlorine Reagent Powder Pillows, Cat. No. $14064-99$

\section{ANALYTICAL PROCEDURE}

1. Pass a known volume of air through a fritted bubbler or a midget impinger containing $0.01 \mathrm{~N} N a O H$. After sampling. neutralize to $\mathrm{pH} 7.0$ with $1 \mathrm{~N} \mathrm{H}_{2} \mathrm{SO}_{4}$.

2. Eill a 25-ml colorimeter bottle with air sampling solution or water to be analyzed.

3. Add the contents of one DPD Total Chlorine Reagent Powder Pillow, and $\mathrm{mix}$ well. 
4. Allow 5 minutes for color development at $20^{\circ} \mathrm{C}$. If chlorine is present, a red color will develop.

5. Fill a colorimeter cell with an untreated water sample, and place it in the cell holder. Insert the Chlorine (DPD Method) Meter Scale in the meter, and adjust the Wavelength Dial to $530 \mathrm{~nm}$.

6. Set the Mode Switch to LEFT SET, and check the left set adjustment. If necessary, adjust the LEFT SET control to align the meter needle with the extreme left mark on the meter scale arc.

7. Set the Mode Switch to NORM, and adjust the RIGHT SET controls for a meter reading of zero $\mathrm{mg} / \mathrm{L}$.

8. Place the prepared sample in the cell holder. Read the $\mathrm{mg} / \mathrm{L}$ chlorine.

9. If the sample temporarily turns yellow when adding the DPD Total Chlorine Reagent or reads above the $1.7 \mathrm{mg} / \mathrm{L}$ mark, the chlorine concentration is too high for the meter scale; and a sample dilution is necessary. A slight loss of chlorine may occur due to the dilution.

\section{REEERENCES}

1. Water Analysis Handbook (Loveland, CO: Hach Co., 1984), p. 2-64.

Reviewed by:

Reviewed by:

Reviewed by:

Reviewed by:

Reviewed by:
Review date:

Review date:

Review date:

Review date:

Review date: 


\section{HEXAVALENT CHROMIUM IN AIR AND WATER}

\section{ABSTRACT}

Hexavalent chromium reacts with 1,5-diphenylcarbohydrazide to produce a purple color absorbing at $540 \mathrm{~nm}$.

\section{APPLICATIONS AND LIMITATIONS}

The range for this method is $0-0.5 \mathrm{mg} / \mathrm{L}$. Mercurous and mercuric ions interfere slightly. Iron, in amounts greater than $1 \mathrm{mg} / \mathrm{L}$, interferes by producing a yellow color. Vanadium interferes in the same manner, but may be overcome by waiting 10 minutes before reading.

\section{APPARATUS}

Hach colorimeter, Model DREL/5

Graduated cylinders, $25 \mathrm{ml}$

Midget impingers, all glass

\section{REAGENTS}

Sodium hydroxide (1N) - Dissolve $40 \mathrm{~g}$ of $\mathrm{NaOH}$ in 1 liter of distilled water.

Nitric acid $(1: 1)$

Hach ChromaVer 3 Chromium Reagent Powder Pillows (1,5-diphenylcarbohydrazide), Cat. No. 12066-66

\section{ANALYTICAL PROCEDURE}

1. Collect samples in two midget impingers in series, using 15 $\mathrm{ml}$ of $1 \mathrm{~N} \mathrm{NaOH}$ as the collecting medium in each impinger.

2. Transfer the samples to a 25-ml graduated cylinder. Acidify with $(1: 1)$ nitric acid to $\mathrm{pH} 4$, and dilute to volume.

3. Place a 5-ml aliquot into a 25-ml sample cell, and dilute to $25 \mathrm{ml}$ with distilled water. Alternatively, take a water sample by filling a clean sample cell to the 25-ml mark. 
4. Add the contents of one Chromaver 3 Chromium Reagent Powder Pillow, and swirl to mix. A purple color will develop if hexavalent chromium is present. Allow at least 5 minutes for the color to develop fully, but do not wait more than 20 minutes.

5. Fill a clean sample cell to the 25-ml mark with the original water sample, and place it in the cell holder. Insert the Chromium, Hexavalent (ChromaVer 3 Method) Meter scale into the meter, and adjust the Wavelength Dial to $540 \mathrm{~nm}$.

6. Set the Mode Switch to LEET SET, and check the left set adjustment. If necessary, adjust the LEFT SET control to align the meter needle with the extreme left malk on the meter scale arc.

7. Set the Mode Switch to NORM, and adjust the RIGHT SET controls for a meter reading of zero $\mathrm{mg} / \mathrm{L}$.

8. Place the prepared sample in the cell holder. Read the mg/I, hexavalent chromium. The results can be expressed as $\mathrm{mg} / \mathrm{L}$ chromate or as $\mathrm{mg} / \mathrm{L}$ sodium chromate by multiplying the $\mathrm{mg} / \mathrm{L}$ hexavalent chromium reading by 2.23 or 3.12 , respectively.

\section{REEERENCES}

1. Water Analysis Handbook (Loveland, CO: Hach Co., 1984), p. $2-73$.

Reviewed by:

Reviewed by:

Reviewed by:

Reviewed by:

Reviewed by:
Review date:

Review date:

Review date:

Review date:

Review date: 


\section{ABSTRACT}

This method describes the analytical techniques used in analyzing compressed breathing air. The specification requirements are listed by the Compressed Gas Association, Inc., 500 Fifth Avenue, New York, NY. Table B-4 lists the CGA Specification G-7.1 (1966). Grade D gas is the breathing air used at Sandia Laboratories.

TABLE B-4

COMPRESSED GAS ASSOCIATION SPECIEICATIONS

\begin{tabular}{|c|c|c|c|c|}
\hline $\begin{array}{c}\text { LIMITING } \\
\text { CHARACTERISTICS }\end{array}$ & GRADE A & GRADE B & GRADE C & GRADE D \\
\hline $\begin{array}{l}\% \mathrm{O}_{2}(\mathrm{v} / \mathrm{v}) \text {. } \\
\mathrm{Balance} \text { mainly } \\
\left.\mathrm{N}_{2} \text { (Note } 1\right)\end{array}$ & Atm. & Atm. & $\begin{array}{l}\text { Atm.' } \\
19 / 23\end{array}$ & $\begin{array}{l}\text { Atm } / \\
19-23\end{array}$ \\
\hline Water & & $\begin{array}{l}\text { None } \\
\text { condensed }\end{array}$ & Note 2 & Note 2 \\
\hline $\begin{array}{l}\text { Hydrocarlions } \\
\text { (condensed) in } \\
\mathrm{mg} / \mathrm{m}^{3} \text { of gas at } \\
\mathrm{STP}\end{array}$ & & None & 5 & 5 \\
\hline Carbon monoxide & & & 50 & 20 \\
\hline Carbon dioxicie & & & & 1000 \\
\hline
\end{tabular}

Note 1: The term "Atm." (atmospheric) denotes the $\mathrm{O}_{2}$ content normally present in atmospheric air $(\sim 21 \%)$; the numerical values cenote the $\mathrm{O}_{2}$ limits for synthesized air.

Note 2: The water content of compressed air required for any particular grade may vary with the intended use from saturated to very dry. If a roocific water limit is required, it should be specifit. = a limiting dewpoint or concentration in $\operatorname{PPM}(\mathrm{V} / \mathrm{V})$. Dh point is expressed in temperature $\left({ }^{\circ} \mathrm{F}\right)$ at 1 atmosphere absolute pressure $(760 \mathrm{~mm} \mathrm{Hg})$. 


\section{ANALYTICAL PROCEDURE}

1. Percent oxygen should be determined by (a) an apparatus employing a comparison tube filled with a color-reactive chemical, or by (b) a gas chromatograph. The technique used must be specific for oxygen.

2. Water content should be determined by one of the following techniques: (a) Eor a qualitative analysis, support the cylinder in an inverted position (valve at the bottom) for 5 minutes. The cylinder and its contents should be at room temperature $\left(22^{\circ} \mathrm{C}\right.$ ). Open the cylinder valve slightly (USE CAUTION!) while the cylinder remains inverted, and vent the air with a barely audible flow into an open dry container for one minute. (CAUTION: A rapid gas flow may cause any liquid to disperse and not collect in the container.) Any water in the breathing air will condense on the dry container. (b) Alternatively, use a gas chromatograph.

3. Condensed Hydrocarbon content should be determined by one of the following techniques: (a) Eor a qualitative analyis, support the cylinder in an inverted position (valve at the bottom) for 5 minutes. The cylinder and its contents should be at room temperature $\left(22^{\circ} \mathrm{C}\right)$. Open the cylinder valve slightly (USE CAUTION!) while the cylinder remains inverted, and vent the air with a barely audible flow into an open dry container for one minute. (CAUTION: A rapid gas flow may cause any liquid to disperse and not collect in the container.) Any oil in the breathing air will condense on the dry container. Alternatively, (b) scrub the air sample with spectral-grade carbon tetrachloride and examine by an IR, or (c) use a gas chromatograph.

4. Carbon Monoxide content should be determined by (a) a gascell equipped infrared analyzer, calibrated at 4.6 microns with appropriate calibration gas standards; or by (b) a gas chromatograph specific for carbon monoxide.

5. Odor should be checked directly by smelling of a moderate flow of air from the container being tested. The presence of a pronounced odor should render the air unsatisfactory for breathing purposes.

6. Carbon Dioxide content should be determined by (a) a gascell equipped infrared analyzer, calibrated at 4.3 microns with appropriate calibration gas standards; or by (b) a gas chromatograph specific for carbon dioxide.

7. Gaseous Hydrocarbon content should be determined by (a) a gas chromatograph with a flame ionization detector, calibrated with methane gas standards; or by (b) a gas-cell equipped infrared analyzer, calibrated at 3.5 microns with methane standards. 
8. Nitrogen Dioxide content should be determined by (a) a gascell equipped infrared analyzer, calibrated at 6.2 microns with appropriate gas standards; or by (b) a suitable colorimetric method (see "Nitrogen Dioxide in Air," Section $B$ of this Manual).

9. Sulfur Dioxide content should be determined by (a) a gascell equipped infrared analyzer, calibrated at 7.3 microns with appropriate gas standards; or by (b) a suitable colorimetric method (see "Sulfur Dioxide in Air," Section B of this Manual).

10. Halogenated Solvent content should be determined by (a) a gas chromatograph or by (b) a gas-cell equipped infrared analyzer.

11. Acetylene content should be determined by a gas-cell equipped infrared analyzer, calibrated at 13.7 microns with appropriate gas standards.

\section{REFERENCES}

1. Commodity specification for Air, CGA Specification G-7.1 (New York: Compressed Gas Association, Inc., 1966).

2. Methods of Air Sampling and Analysis, ed J. P. Lodge, Jr. (3rd ed; Chelsea, MI: Lewis Publishers, 1989).

Reviewed by:

Reviewed by:

Reviewed by:

Reviewed by:

Reviewed by:
Review date:

Review date:

Review date:

Review date:

Review date: 
THIS PAGE INTENTIONALLY LEFT BI.ANK 


\section{CYANIDES AND HYDROCYANIC ACID IN AIR AND WATER \\ (Colorimetric Method)}

\section{ABSTRACT}

Cyanide is neutralized and converted to cyanogen chloride by reaction with chloramine- $\mathrm{T}$. This reacts with pyridinepyrazolone reagent to form a blue color, which can be read at $630 \mathrm{~nm}$.

\section{APPLICATIONS AND LIMITATIONS}

Sensitivity and precision can be improved by extracting the aqueous solution with n-butyl alcohol and then reading the absorbance at $630 \mathrm{~nm}$. For aqueous color readings, the effective range is $1-5 \mu \mathrm{g}$ and sensitivity is $0.5 \mu \mathrm{g}$. For the extracted color, the range is $0.2-2.0 \mu \mathrm{g}$, while the sensitivity is $0.1 \mu \mathrm{g}$.

only minor limitations occur with this method. The salt content of sample and standards should be the same to obtain colors of comparable intensity. Thiocyanates and cyanogen will give the same reaction as cyanides.

\section{ES\&H NOTES}

Phenylhydrazine is designated as a Class A2 carcinogen by the ACGIH. Solid cyanides are highly toxic by ingestion. These materials should be handled in a Designated Area, typically a laboratory hood. The room and/or hood shall be clearly labeled with a sign indicating that a carcinogen is in use. Wash hands well after handling.

\section{APPARATUS}

Spectrophotometer, Hewlett-Packard Model 8450 A, for use with $1-\mathrm{cm}$ cells at $620-630 \mathrm{~nm}$

Eritted bubbler

Assorted laboratory glassware

\section{REAGENTS}

Sodium hydroxide (1N) - Dissolve $40 \mathrm{~g}$ of $\mathrm{NaOH}$ in 1 liter of distilled water. 
Sodium hydroxide (O.2N) - Dissolve 8 g of $\mathrm{NaOH}$ in 1 liter of distilled water.

Acetic acid, conc.

Acetic acid, $1: 4$

Chloramine-T solution - Dissolve $1 \mathrm{~g}$ in $100 \mathrm{ml}$ of distilled water. PREPARE FRESH DAILY

3-Methyl-1-phenyl-5-pyrazolone solution, Eastman 1397 or equivalent - Prepare a saturated solution in warm water $(\cong 0.5 \mathrm{~g} / 125 \mathrm{ml}$ water $)$.

Ethyl alcohol $(95 \%)$

Phenylhydrazine

Bis-pyrazolone, Eastman 6969 or equivalent - Dissolve $17.4 \mathrm{~g}$ of 3-methyl-1-phenyl-5-pyrazolone in $100 \mathrm{ml}$ of ethyl.

alcohol. Add $25 \mathrm{~g}$ of phenylhydrazine, freshly distilled under reduced pressure. Reflux in an all-glass still for 10 to 12 hours. Filter while hot, wash with $95 \%$ ethyl alcohol, and air-dry.

Pyridine

Mixed pyridine-pyrazolone reagent - Mix $125 \mathrm{ml}$ of saturated pyrazolone solution with a solution containing $0.025 \mathrm{~g}$ of bis-pyrazolone dissolved in $25 \mathrm{ml}$ of pyridine. Store in a dark bottle. The mixed reagent develops a pink color on standing. PREPARE FRESH DAILY.

Disodium hydrogen phosphate solution - Dissolve $5 \mathrm{~g}$ of anhydrous $\mathrm{Na}_{2} \mathrm{HPO}_{4}$ in $100 \mathrm{ml}$ of distilled water.

n-Butyl alcohol

Cyanide stock standard ( $1 \mathrm{mg} \mathrm{CN} / \mathrm{ml}$ ) - Dissolve $2,510 \mathrm{~g}$ of $\mathrm{KCN}$ in 1 liter of distilled water.

Cyanide working standard $(1 \mu \mathrm{g} \mathrm{CN} / \mathrm{ml})$ - Dilute $10 \mathrm{ml}$ of stock standard to $1000 \mathrm{ml}$ with distilled water, $\mathrm{mix}$, and make a second dilution by pipetting $10 \mathrm{ml}$ into a $100-\mathrm{m}$ l. volumetric flask. PREPARE ERESH DAILY.

\section{ANALYTICAL PROCEDURE}

1. Eor air samples, pass a known volume of air through a fritted bubbler containing $1 \mathrm{~N} \mathrm{NaOH}$. Use two bubblers in series. Sample at a rate of 1 liter/min. 
2. Pipet one or more aliquots (up to about $10 \mathrm{ml}$ ) of the air sample absorption solution or water sample into a 25-ml graduated cylinder. Dilute to $15 \mathrm{ml}$ with $0.2 \mathrm{~N} \mathrm{NaOH}$, and neutralize each with $1: 4$ acetic acid to a $\mathrm{pH}$ of $6-7$.

3. Add $0.2 \mathrm{ml}$ of chloramine-T solution, stopper, and mix. Allow 2 minutes for the reaction to occur.

4. Add $5 \mathrm{ml}$ of mixed pyridine-pyrazolone reagent, stopper, and mix. Allow 20 minutes for color to develop. Dilute to 25 $\mathrm{ml}$ with distilled water. Read the absorbance at $620 \mathrm{~nm}$.

5. If greater sensitivity is needed, add $1 \mathrm{ml}$ of disodium hydrogen phosphate and $10 \mathrm{ml}$ of butyl alcohol, $\mathrm{mix}$, and read the absorbance at $630 \mathrm{~nm}$.

6. Prepare a blank from $15 \mathrm{ml}$ of $0.2 \mathrm{~N} \mathrm{NaOH}$ and standards in the range of $0.2-1 \mu \mathrm{g} \mathrm{CN}$. Neutralize to a $\mathrm{pH}$ of $6-7$ with $1: 4$ acetic acid, and proceed as in step 3. Plot a calibration curve of $\mu \mathrm{g} C \mathrm{~N}$ versus the absorbance of the standard.

\section{CALCULATIONS}

$\mu \mathrm{g} C \mathrm{~N} / \mathrm{L}=\mu \mathrm{g} \mathrm{CN}$ in sample from curve $\mathrm{x} 1000$ $\mathrm{ml}$ aliquot

\section{REEERENCES}

1. J. Epstein, "Estimation of Microquantities of Cyanide," Anal Chem 19:272 (1947).

2. F.J. Ludzack, W.A. Moore, and C.C. Ruchhuft, "Determination of Cyanides in Water and Waste Samples," Anal Chem 26:1784 (1954).

Reviewed by:

Reviewed by:

Reviewed by:

Reviewed by:

Reviewed by:
Review date:

Review date:

Review date:

Review date:

Review date: 
THIS PAGE INTENTIONALLY LEFT BLANK 


\section{CYANIDES IN AIR}

\section{(Specific Ion Electrode Method)}

\section{ABSTRACT}

Air samples, collected in $\mathrm{NaOH}$ via a bubbler, are analyzed with a cyanide specific ion electrode.

\section{APPLICATIONS AND LIMITATIONS}

This method is a simple alternative to the colorimetric technique (see "Cyanides and Hydrocyanic Acid in Air and Water" in section $B$ of this Manual). The working range is $0.5-15 \mathrm{mg} / \mathrm{m}^{3}$ for a 90-liter air sample, and the estimated detection limit is $2.5 \mu \mathrm{g}$ of $\mathrm{CN}^{-}$.

Numerous ions interfere, including sulfide, chloride, iodide, bromide, cadmium, zinc, silver, nickel, cuprous iron, and mercury. Sulfides irreversibly poison the cyanide electrode and must be removed before analysis (see Reference 1).

\section{ES\&H NOTES}

Solid cyanides are highly toxic by ingestion. They should be handled in a laboratory hood. Wash hands well after handling.

\section{APPARATUS}

$\mathrm{pH}$ Meter

Cyanide specific ion electrode

Reference electrode

Magnetic stirrer and stirring bars

Assorted laboratory glassware

\section{REAGENTS}

Sodium hydroxide (O.1N) - Dissolve $4 \mathrm{~g}$ of $\mathrm{NaOH}$ in 1 liter of distilled water.

Stock cyanide standard $(1000 \mu \mathrm{g} / \mathrm{ml})$ - Dissolve $0.250 \mathrm{~g}$ of KCN or $0.188 \mathrm{~g}$ of $\mathrm{NaCN}$ in $100 \mathrm{ml}$ of $0.1 \mathrm{~N} \mathrm{NaOH.} \mathrm{PREPARE}$ ERESH WEEKLY. 


\section{ANALYTICAL PROCEDURE}

1. Dilute the samples to $50 \mathrm{ml}$ with $0.1 \mathrm{~N} \mathrm{NaOH}$, and transfer them to 100-ml beakers. Add a stirring bar to each beaker.

2. Prepare a series of cyanide standards by successively diluting $10 \mathrm{ml}$ of the cyanide stock standard to $100 \mathrm{ml}$ with $0.1 \mathrm{~N} \mathrm{NaOH.} \mathrm{STANDARDS} \mathrm{SHOULD} \mathrm{BE} \mathrm{PREPARED} \mathrm{ERESH} \mathrm{DAILY.}$

3. Allow all solutions to equilibrate to the same temperature, taking care to avoid evaporation.

4. Immerse the cyanide and reference electrodes in $50 \mathrm{ml}$ of $0.1 \mathrm{~N} \mathrm{NaOH}$ (sample blank) to determine the baseline reading. Turn on the magnetic stirrer and gently agitate while the potential reading stabilizes. Record the $\mathrm{mV}$ reading.

5. Repeat step 4 for all sample solutions.

6. Analyze all standards as in step 4, beginning with the lowest concentration. Prepare a calibration graph on semilog paper.

7. Determine the cyanide ion concentrations from the graph.

\section{REEERENCES}

1. "Cyanides, Aerosol and Gas," NIOSH Manual of Analytical Methods, Vol. 1, U.S. Department of Health and Human Services Publication No. 84-100, ed P.M. Eller (3rd ed; Washington, DC: U.S. Government Printing Office, 1984), Method 7904.

Reviewed by:

Reviewed by:

Reviewed by:

Reviewed by:

Reviewed by:
Review date:

Review date:

Review date:

Review date:

Review date: 


\section{ELUORIDES AND HYDROGEN ELUORIDE IN AIR AND WATER}

\section{ABSTRACT}

Eluoride is determined colorimetrically by the reaction between the fluoride ion and a dark red zirconium-dye lake. As the amount of fluoride increases, the color of the dye lake becomes progressively lighter and can be measured at $580 \mathrm{~nm}$.

\section{APPLICATIONS AND LIMITATIONS}

This technique obeys Beer's Law between 0.0 and $2 \mathrm{mg} / \mathrm{L} \mathrm{F} \mathrm{F}^{-}$, with a detection limit of about $0.02 \mathrm{mg} / \mathrm{L}$.

The SPADNS method is subject to errors where interfering ions may be present. They are:

\begin{tabular}{|l|c|c|}
\hline \multicolumn{1}{|c|}{ INTEREERING ION } & CONC (PPM) & ERROR, $\mathrm{mg} / \mathrm{L} \mathrm{F} \mathrm{F}^{-*}$ \\
\hline $\left.\mathrm{Alkalinity} \mathrm{(as} \mathrm{CaCO}_{3}\right)$ & 5000 & -0.1 \\
$\mathrm{Al}^{+3}$ & 0.1 & -0.1 \\
$\mathrm{Cl}^{-}$ & 7000 & +0.1 \\
$\mathrm{Fe}^{+3}$ & 10 & -0.1 \\
$\mathrm{Hexametaphosphate}\left(\mathrm{NaPO}_{3}\right) 6$ & 1.0 & +0.1 \\
$\mathrm{PO}_{4}^{-3}$ & 16 & +0.1 \\
$\mathrm{SO}_{4}^{-2}$ & 200 & +0.1 \\
\hline
\end{tabular}

*Error at $1.0 \mathrm{mg} / \mathrm{L} \mathrm{E}^{-}$

To remove most interferences, it is necessary to distill the water sample. As these interferences are neither linear nor additive, mathematical compensation will be incorrect. The temperature of the samples and standards must be the same, or the results will be incorrect.

\section{ES\&H NOTES}

Sodium arsenite is designated as a known human carcinogen by the NTP. This material should be handled in a Designated Area, typically a laboratory hood. The rnom and/or hood shall be clearly labeled with a sign indicating that a carcinogen is in use. 


\section{APPARATUS}

Hach colorimeter, Model DREL/5

Distillation apparatus, consisting of a 1-liter round-bottom long-neck boiling flask, a connecting tube, a condenser, a thermometer adapter, and a thermometer.

Midget impinger

Assorted laboratory glassware

\section{REAGENTS}

Sodium hydroxide solution (0.1N)

Hach standard fluoride solution ( 1 PPM F-), Cat. No. 291-16

Sodium arsenite solution - Add $5 \mathrm{~g}$ of $\mathrm{NaAsO}_{2}$ to 1 liter of distilled water.

Hach SPADNS fluoride reagent, Cat. No. 444-11

\section{ANALYTICAL PROCEDURE}

1. Pass a known volume of air through a midget impinger containing $0.1 \mathrm{~N} \mathrm{NaOH.} \mathrm{Collect} \mathrm{in} \mathrm{series.} \mathrm{After} \mathrm{sampling,}$ transfer each air sample solution to a 25-ml graduated cylinder; and dilute with distilled water to the $25-\mathrm{ml}$ mark.

2. Eill a 25-ml graduated cylinder with the water sample to be analyzed.

3. Fill a 25-ml graduated cylinder with the standard 1.0-PPM fluoride solution. (The concentration needs to match that of the sample closely.)

4. Allow the standard and unknown samples to equilibrate at room temperature.

5. If the sample contains chlorine, remove it by adding 2 drops of sodium arsenite solution. (The SPADNS reagent already contains some sodium arsenite.)

6. Pipet $5 \mathrm{ml}$ of SPADNS Fluoride Reagent into each graduated cylinder, stopper, and mix well. Transfer each to colorimeter cells.

7. Insert the Fluoride (SPADNS METHOD) Meter scale into the Hach colorimeter, and adjust the Wavelength Dial to $580 \mathrm{~nm}$. 
8. Set the Mode Switch to LEET SET, and check the left set adjustment. If necessary, adjust the LEFT SET control to align the meter needle with the extreme left mark on the meter scale arc.

9. Set the Mode Switch to NORM, and adjust the RIGHT SET controls for a meter reading equal to the fluoride standard.

10. Place the prepared sample in the cell holder. Read the $\mathrm{mg} / \mathrm{L}$ of fluoride.

\section{CALCULATIONS}

$$
\begin{aligned}
& \text { Total } \mu \mathrm{g} \mathrm{F}^{-} \text {in sample }=\left(\mu \mathrm{g} / \mathrm{ml} \mathrm{F^{- }}\right) \times \text { sample volume }(\mathrm{ml}) \\
& \mathrm{mg} \mathrm{F}^{-} / \mathrm{m}^{3} \quad=\mu \mathrm{g} \mathrm{F}^{-} / \mathrm{liters} \text { of air sampled } \\
& \mathrm{mg} \mathrm{HE} / \mathrm{m}^{3}=(\mu \mathrm{g} \mathrm{F} / \text { liters of air sampled }) \times 1.05
\end{aligned}
$$

\section{REEERENCES}

1. Water Analysis Handbook (Loveland, CO: Hach Co., 1984), p. $2-113$.

2. Standard Methods for the Examination of Water and Wastewater ( 16 th ed; Washington, DC: American Public Health Association, 1985 ), p. 352 .

3. "Tentative Method of Analysis for Eluoride Content of the Atmosphere and Plant Tissues (Manual Methods)," Methods of Air Sampling and Analysis, ed J.P. Lodge (3rd ed; Chelsea, MI: Lewis Publishers, 1989), Method 203.

Reviewed by:

Reviewed by:

Reviewed by:

Reviewed by:

Reviewed by:
Review date:

Review date:

Review date:

Review date:

Review date: 
TIIS PAGE INTENTIONALLY LEFT BLANK 


\section{FLUORIDE IN URINE}

\section{ABSTRACT}

Fluoride is separated directly from urine by ion exchange, then eluted and determined colorimetrically at $536 \mathrm{~nm}$.

\section{APPARATUS}

Spectrophotometer, Hewlett-Packard Model $8450 \mathrm{~A}$

Chromatographic columns, Kontes No. K-42225 Chromaflex Column No. 2, with $125-\mathrm{ml}$ reservoir

Assorted laboratory glassware

\section{REAGENTS}

Dowex $50 \mathrm{~W}-\mathrm{X} 8,20$ to 50 mesh in the free acid form as a urine preservative

Hydrochloric acid (3M) - Dilute one part of conc. HCl to 3 parts of distilled water.

Dowex $50 \mathrm{~W}-\mathrm{X} 8,100$ to 200 mesh in the free acid form

Ethyl alcohol

Sand, white quartz, 60 to 120 mesh

Charcoal, coconut, acid-washed, activated, 50 to 100 mesh

Dowex $1-x 8,100$ to 200 mesh in the chloride form

Sodium hydroxide solution (3M) - Dissolve $120 \mathrm{~g}$ of $\mathrm{NaOH}$ in 1 liter of distilled water.

Sodium hydroxide $(0.3 \mathrm{M})$ - Dissolve $12 \mathrm{~g}$ of $\mathrm{NaOH}$ in 1 liter of distilled water.

Fluoride standard $\left(10 \mu \mathrm{g} / \mathrm{ml} \mathrm{F}^{-}\right)$- Dissolve $0.221 \mathrm{~g}$ of $\mathrm{NaF}$ in 1 liter of $0.3 \mathrm{~N} \mathrm{NaOH}$.

Eriochrome Cyanine R reagent - Dissolve $1.80 \mathrm{~g}$ of Eriochrome Cyanine $\mathrm{R}$ in 1 liter of distilled water.

Zirconium reagent - Dilute a solution of $0.265 \mathrm{~g}$ of $\mathrm{ZrOCl}_{2}$ • $8 \mathrm{H}_{2} \mathrm{O}$ in $50 \mathrm{ml}$ of water to 1 liter with conc. $\mathrm{HCl}$. 
Mixed color reagent - Mix equal volumes of zirconium reagent and Eriochrome Cyanine $\mathrm{R}$ reagent (add zirconium to dye).

Five $\mathrm{ml}$ of this mixed reagent is required for each fraction collected.

Reference solution - To obtain the zero absorbance reading, add $10 \mathrm{ml}$ of the dye solution to $100 \mathrm{ml}$ of water; then add $10 \mathrm{ml}$ of a solution prepared by diluting $7 \mathrm{ml}$ of conc. HCl to $10 \mathrm{ml}$ with water.

\section{PREPARATION OE RESINS}

Dowex $50 \mathrm{~W}-\mathrm{X} 8,20$ to 50 mesh, for urine preservation - Wash the resin in a large column with 3 volumes of distilled water; then wash with 5 volumes of $3 \mathrm{M} \mathrm{HCl}$. (Volume is that equivalent to the amount of resin.) Einally, wash with distilled water until the effluent is neutral to $\mathrm{pH}$ test paper. Drain the column, transfer the resin to a Pyrex tray, and dry at $40^{\circ} \mathrm{C}$.

Dowex $50 \mathrm{~W}-\mathrm{X} 8,100$ to 200 mesh - In a large column, wash with 3 volumes of ethyl alcohol, 3 volumes of distilled water, and 5 volumes of $3 \mathrm{M} \mathrm{HCl}$; then wash with water until the effluent is neutral to $\mathrm{pH}$ test paper. Store as a $1: 1$ siurry in distilled water.

Sand - Digest at $100^{\circ} \mathrm{C}$ for 2 hours with $20 \% \mathrm{NaOH}$, wash with distilled water, and then digest for 2 hours at $100^{\circ} \mathrm{C}$ in $3 \mathrm{M}$ $\mathrm{HCl}$. Finally, wash with distilled water until neutral to $\mathrm{pH}$ test paper, transfer to a Pyrex tray, and dry at $100^{\circ} \mathrm{C}$.

\section{COLUMN PREPARATION}

I'retreatment Column: Add $2 \mathrm{ml}$ of water to the column, with the stopcock closed; then add $20 \mathrm{ml}$ of a $1: 1$ slurry of charcoal. Drain all except $2 \mathrm{ml}$ of water, then add $2 \mathrm{ml}$ of a 1:1 slurry of 100 to 200 mesh Dowex $50 \mathrm{~W}-\mathrm{X} 8$. When the resin has settled, but the water is not completely drained, add a $2-c m$ thick layer of sand.

Separation Column: Add $2 \mathrm{ml}$ of water to a column, with the stopcock closed. Add $20 \mathrm{ml}$ of a $1: 1$ slurry of Dowex 1-X8 ( 100 to 200 mesh). Twirl the tube before the water drains to the level the resin surface. Add $2 \mathrm{~cm}$ of sand before all the water drains from the column. Convert the resin to the hydroxide form by adding $150 \mathrm{ml}$ of $3 \mathrm{M} \mathrm{NaOH}$. Wash with water until the effluent is neutral to $\mathrm{pH}$ test paper. 


\section{ANALYTICAL PROCEDURE}

1. Collect urine samples in vessels containing $5 \mathrm{ml}$ of 20-50 mesh Dowex $50 \mathrm{~W}$-X8 per $100 \mathrm{ml}$ of urine.

2. Dilute $25 \mathrm{ml}$ of the preserved urine to $250 \mathrm{ml}$.

3. Pass $50 \mathrm{ml}$ of diluted urine through the pretreatment column, and discard the effluent.

4. Pass the remaining $200 \mathrm{ml}$ of diluted urine through the column, and collect the effluent in a polyethylene bottle.

5. Pass $100 \mathrm{ml}$ of the clarified urine through each of two Dowex $1-\mathrm{X} 8$ columns.

6. Rinse the columns with $50 \mathrm{ml}$ of distilled water, and allow them to stand overnight. Do not drain; let approximately 2 $\mathrm{ml}$ of water remain on top of the resin.

7. Flush the water from the columns with $10 \mathrm{ml}$ of $0.3 \mathrm{M} \mathrm{NaOH}$. Discard.

8. Elute the fluoride with five 25-ml portions of $0.3 \mathrm{M} \mathrm{NaOH}$; collect each 25-ml fraction in a colorimeter tube.

9. Prepare standards of 0 to $25 \mu \mathrm{g} \mathrm{F}$ in $25 \mathrm{ml}$ of $0.3 \mathrm{M} \mathrm{NaOH}$.

10. To each standard and fraction collected, add $5 \mathrm{ml}$ of mixed color reagent.

11. Read absorbance at $536 \mathrm{~nm}$ versus the reference solution.

\section{CALCULATIONS}

1. Plot absorbance versus $\mu \mathrm{g} \mathrm{F}^{-}$for the standards, and determine the content of each fraction.

2. Add the concentrations of fluoride in all 10 fractions for each sample.

3. The total fluoride in the fractions is the amount per $25 \mathrm{ml}$ of urine.

4. The $\mu \mathrm{g} /$ iter $=$ fraction total $\times 40$. 


\section{REEERENCES}

1. N.A. Talvitie and L.W. Brewer, "Separation of Fluoride by Ion Exchange: Application to Urine Analysis," Am Ind Hyg Assoc J 2(2):287 (1960).

Reviewed by:

Reviewed by:

Reviewed by:

Reviewed by:

eviewed by:
Review date:

Review date:

Review date:

Review date:

Review date: 


\title{
INDUCTIVELY-COUPLED PLASMA SPECTROSCOPY
}

\begin{abstract}
Inductively-coupled plasma (ICP) spectroscopy is an atomic emission technique which can quantitatively identify elements in the PPM to PPB range. The liquid sample is converted into a fine aerosol which is carried by an argon stream into a hightemperature plasma. The plasma desolvates the droplets and dissociates the sample into individual excited atoms and ions which emit light at wavelengths characteristic of the elements present. The intensity is directly proportional to the concentration of the element present in the sample. The technique is comparable to atomic absorption ( $A A$ ) in many respects, but can generally be used for analysis of a wider range of elements.
\end{abstract}

\section{APPLICATIONS AND LIMITATIONS}

The ICP has several advantages when compared with atomic absorption techniques, including the following:

1. The programmable grating allows the rapid analysis of multiple elements, whereas $A A$ is limited to one element per lamp.

2. The detection limits are generally better than those of flame $A A$ but less than graphite furnace $A A$. The detection limits for most elements are given in Table $B-5$.

3. The high linear dynamic range, often 4-5 orders of magnitude, permits the determination of major, minor, and trace elements without dilution of the sample. The maximum linear range values for certain elements are listed in Table $\mathrm{B}-5$.

4. The high temperature of the plasma allows the deternination of refractory elements, such as $\mathrm{P}, \mathrm{B}, \mathrm{W}, \mathrm{Zr}$, and $\mathrm{U}$.

5. Use of the plasma reduces chemical matrix effects. For example, refractories and metal oxides seldom form in the plasma. In addition, the presence of easily oxidized ele"ents, such as alkalis, is less likely to affect the signal level than in $A A$. 
There are several limitations to the use of ICP. Actual method detection limits are matrix dependent and may vary with the sample. It is important to run reagent blanks for each batch of samples to correct for contaminants and to run interference samples to determine interelement correction factors for each element. Because of the sensitivity of the technique, it is best to use ultra-high purity grade reagents or redistilled acids. Finally, the most sensitive wavelength is not necessarily the appropriate one to use. Depending upon the interferences present or the concentration of the analyte, it may be necessary or desirable to select an alternate, less sensitive wavelength for the analysis.

\section{ES\&H NOTES}

Some of the metals determined by ICP are designated as carcinogens by the ACGIH and by the IARC. These materials should be handled in a Designated Area, typically a laboratory hood, to minimize respiratory exposure. The room and/or hood shall be clearly labeled with a sign indicating that a carcinogen is in use.

Because hydrofluoric acid is highly toxic and corrosive, avoid inhalation, ingestion, or contact. Wear appropriate gloves and handle in a hood. Wash skin after use to avoid potential tissue damage.

\section{APPARATUS}

Inductively Coupled Plasma Spectrometer, Perkin-Elmer Model. ICP $/ 6500$

Peristaltic pump

Assorted laboratory equipment such as glassware and plasticware, hot plates, and pipettes

\section{REAGENTS}

See "General Procedures for Atomic Absorption Spectroscopy," Section B of this Manual, for a list of appropriate reagents.

\section{SAMPLE PREPARATION}

Sample preparation is identical to that listed in "General Procedures for Atomic Absorption Spectroscopy," Section B of this Manual. 


\section{ANALYTICAL PROCEDURE}

1. Turn on the power to the ICP, the RE generator, the computer, and the printer. Turn on the water and argon supplies.

2. Set up the instrument as indicated in the Instruction Manual, Reference 3 .

3. Select appropriate wavelengths and conditions using the Methods Development Manual (Reference 4) or Table B-5.

4. Aspirate a series of standards and samples, following the instructions on the computer terminal. The computer program will calculate the calibration curve and the elemental concentrations in the samples.

\section{QUALITY ASSURANCE}

Good quality control procedures encourage the use of the following standards and check samples (Reference 9):

1. Calibration blank - used to establish the analytical curve and to flush the system between samples. Dilute $2 \mathrm{ml}$ of $1: 1$ $\mathrm{HNO}_{3}$ plus $10 \mathrm{ml}$ of $1: 1 \mathrm{HCl}$ to $100 \mathrm{ml}$ with distilled water.

2. Reagent blank - used to correct for contaminants in the reagents. Carry all reagents used in the sample preparation, in the same volumes as the samples, through the entire procedure.

3. Instrument check standard - a multi-element standard of known concentration, used to verify instrument drift. The concentrations used should equal. the midpoint of the respective calibration curves.

4. Interference check sample - a standard containing both interfering and analyte elements in known concentrations, used to determine interelement correction factors. Spike a known sample with $100 \mu \mathrm{g} / \mathrm{L}$ or 5 times the detection limjt of anticjpatcd interferents.

5. LA control sample - used to verify calibration standards. obiajn from an outside source a standard at a concentration near 1 PPM in the same acid matrix as the calibration standard. The analyzed result should be $\pm 5 \%$ of the true value. 


\section{REFERENCES}

1. P.W.J.M. Boumans, Line Coincidence Tables for Inductively Coupled Plasma Atomic Emission Spectrometry (New York:

Pergamon Press, 1980).

2. M.L. Parsons, A. Foster, and D. Anderson, An Atlas of Spectral Interferences in ICP Spectroscopy (New York: Plenum Press, 1980).

3. Instructions for ICP/6500 Inductively Coupled Plasma system, Publication No. 0993-8131. (Norwalk, CT: The Perkin-Elmer Corp., 1984).

4. G.F. Wallace and P. Barrett, Analytical Methods Development for Inductively Coupled Plasma spectrometry, Publication No. 0993-9609 (Norwalk, CT: The Perkin-Elmer Corp., 1981).

5. T. Hayakawa, F. Kikui, and S. Ikeda, "The Determination of I, P, B, S, As and Sn by Inductively Coupled Plasma Emission Spectroscopy Using Lines at Vacuum Ultra-Violet Wavelengths," Spectrochim Acta 37B(12):1069 (1.982).

6. D.D. Nygaard and D.A. Leighty, "Inductively Coupled Plasma Emission Lines in the Vacuum Ultraviolet," Appl Spectrosc $39(6): 968$ (1985).

7. ICP Spectrometry: Instrumentation and operating Parameters, Publication No. ICP-252-08-MK-E (Sunland, CA: Bausch \& Lomb/Applied Research Laboratories).

8. Unpublished data (Metuchen, NJ: Jobin-Yvon/Instruments SA).

9. The Eederal Register, Part V: Environmental Protection Agency 49(209):43433 (Oct. 26, 1984).

Reviewed by:

Reviewed by:

Reviewed by:

Reviewed by:

Reviewed by:
Review date:

Review date:

Review date:

Review date:

Review date: 


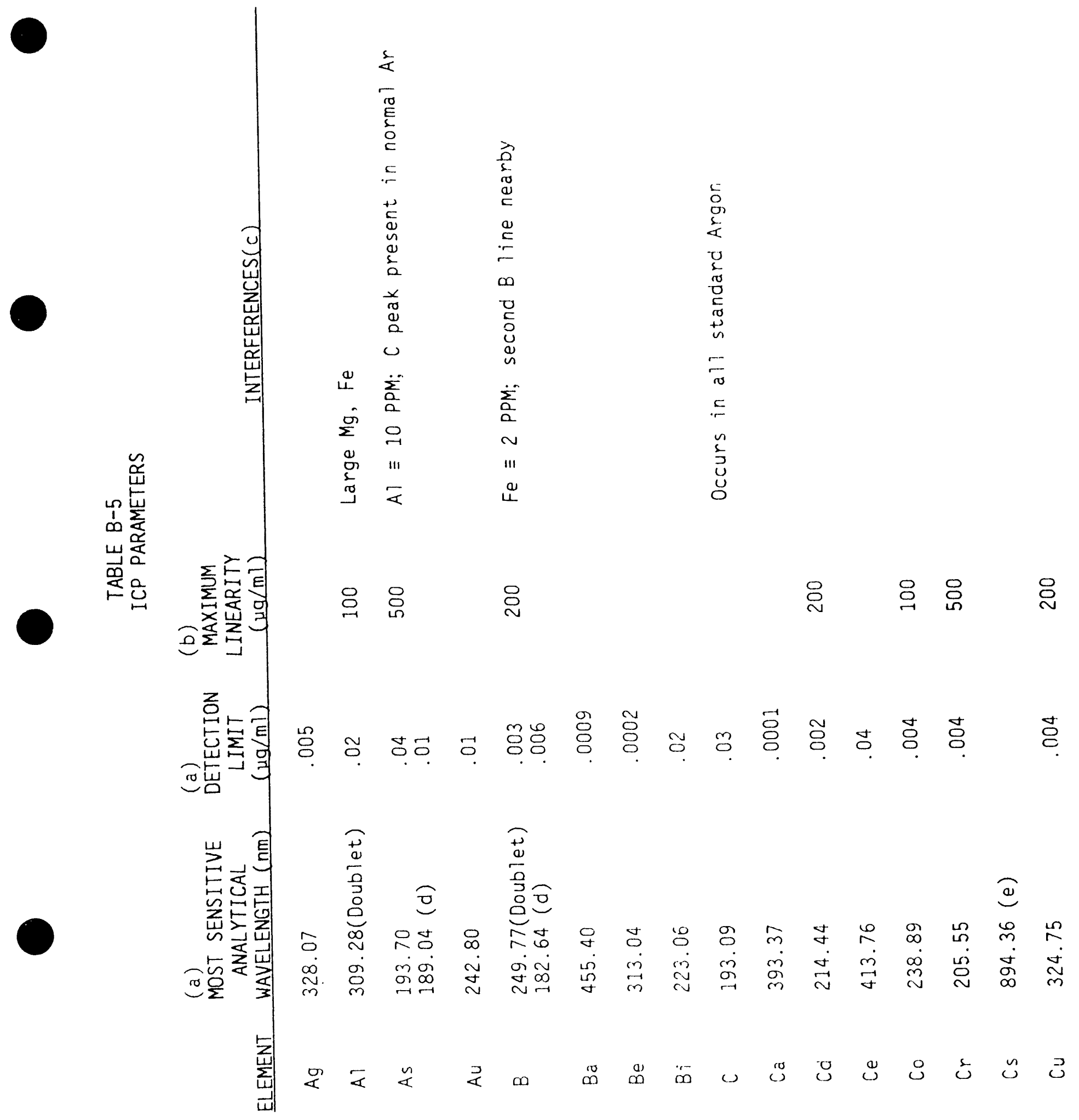




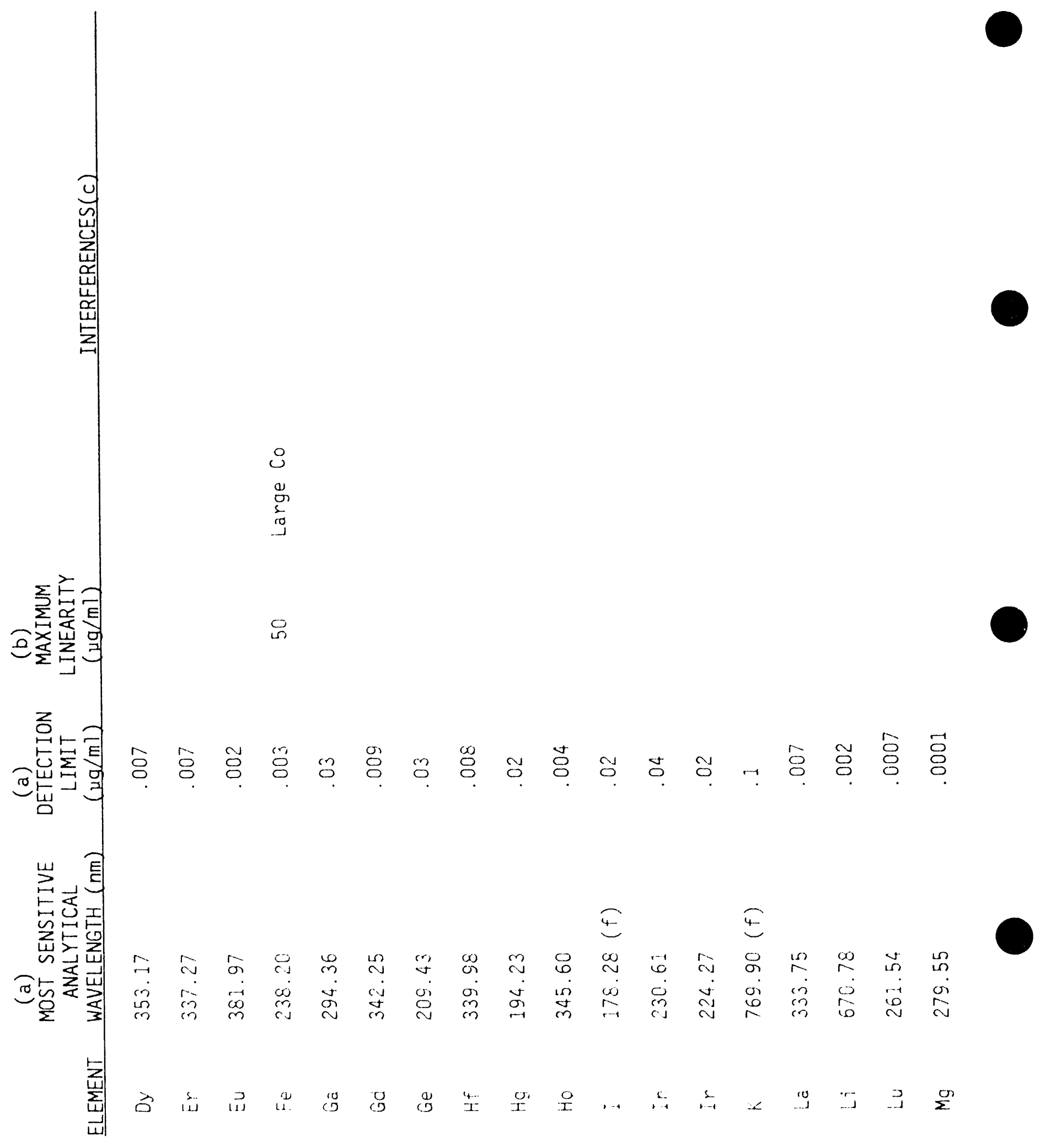




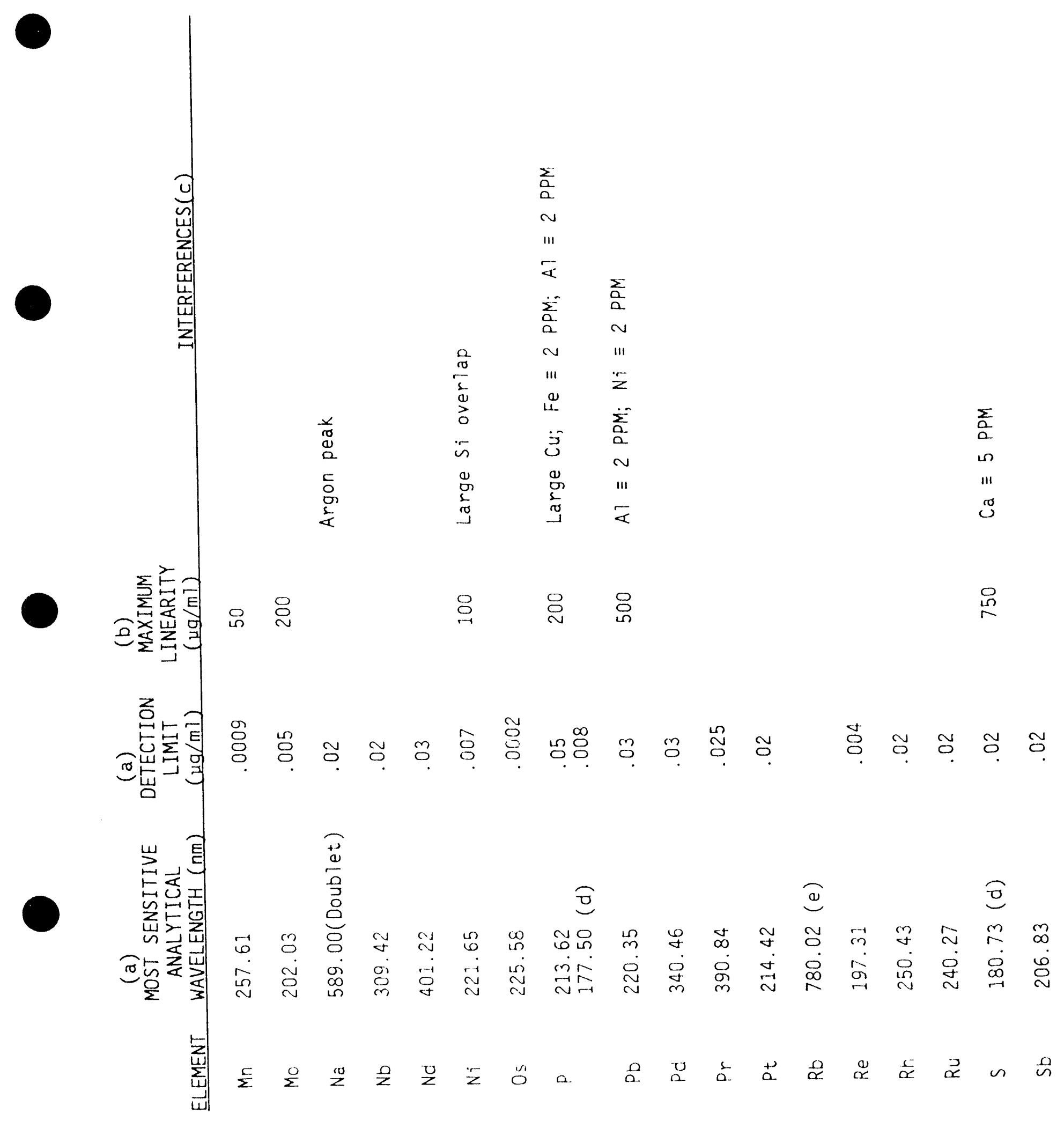




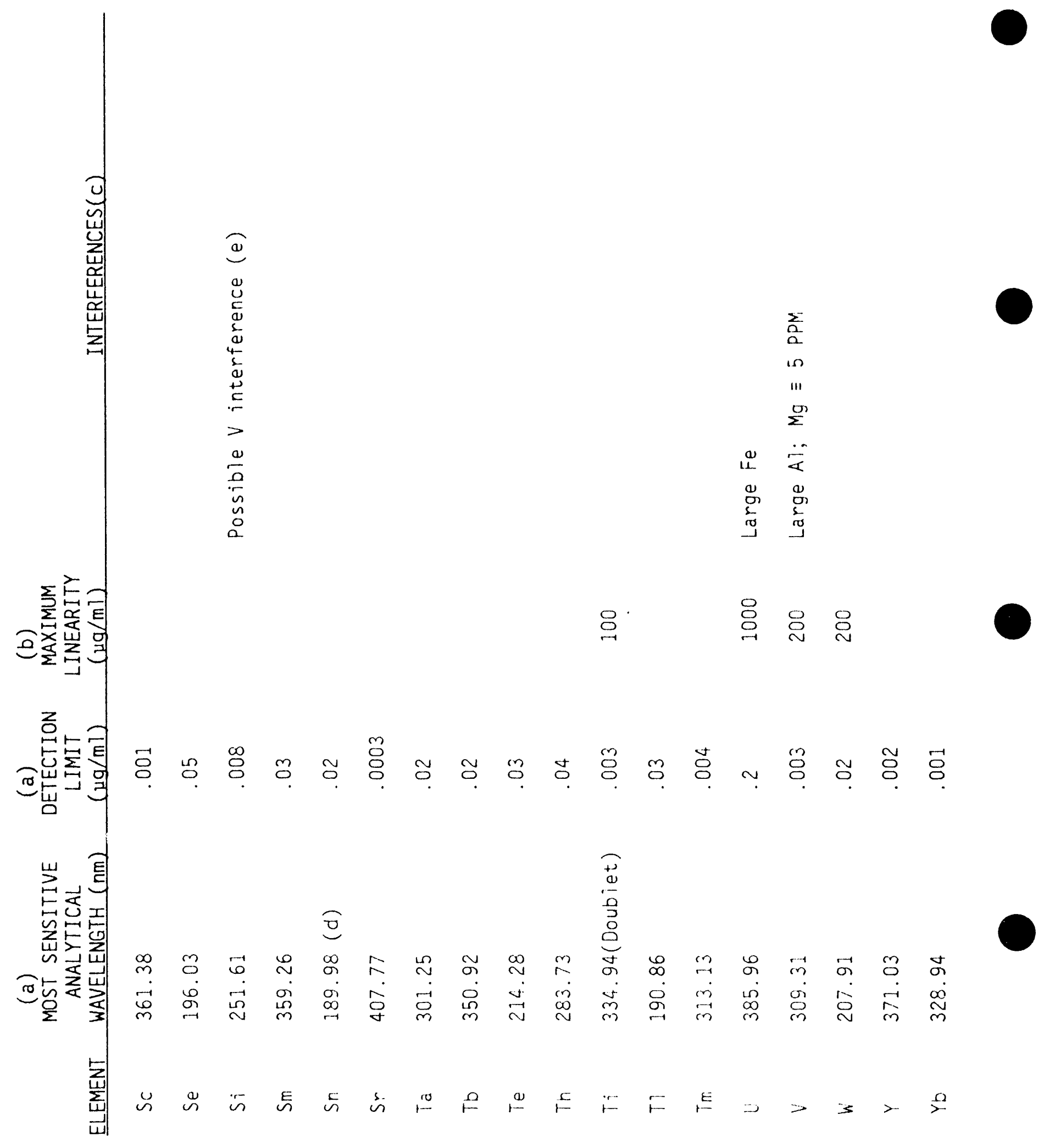




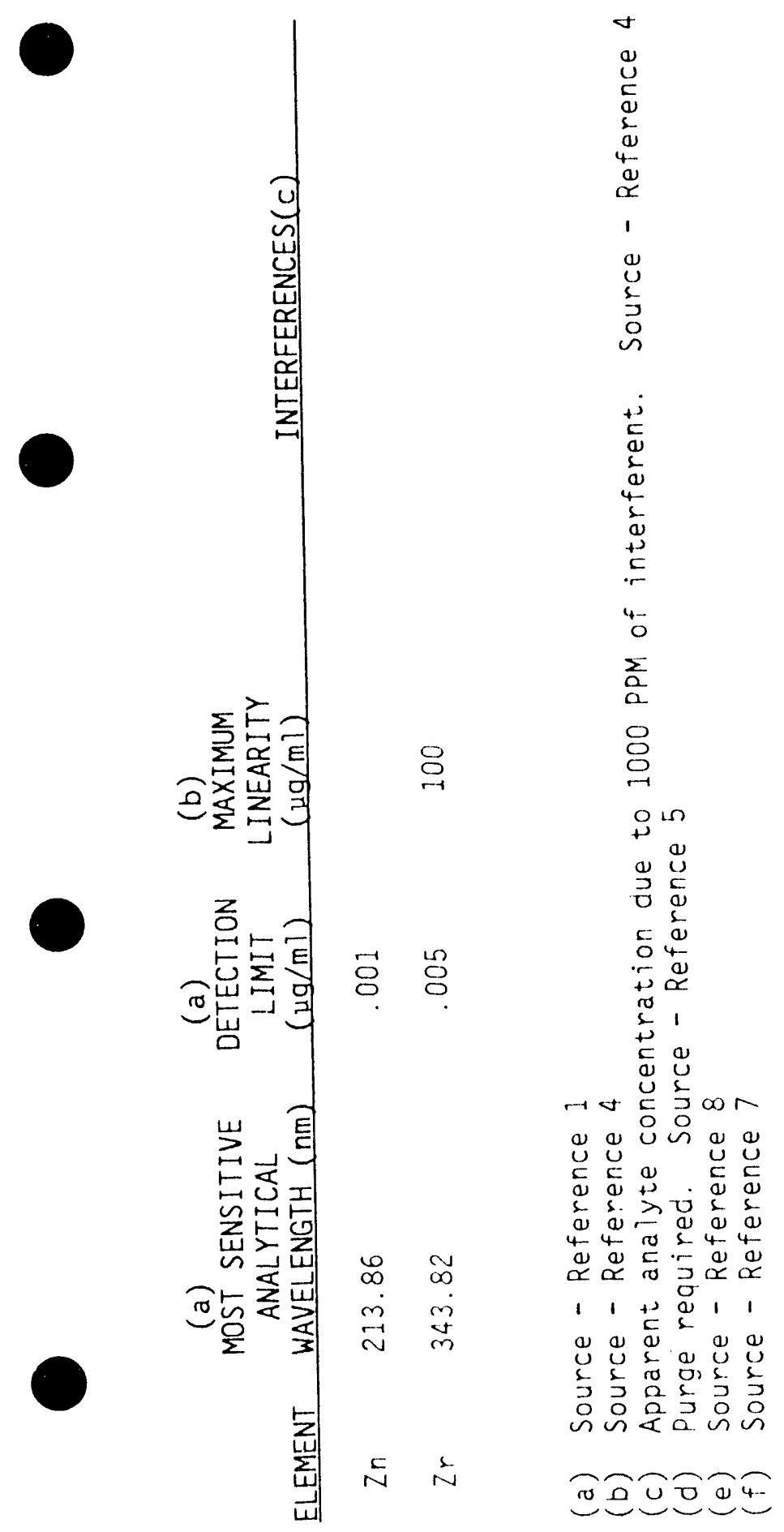


THIS PAGE INTENTIONALLY LEFT BLANK 


\title{
TOTAL LEAD AND COPPER IN DRINKING WATER
}

\begin{abstract}
First-draw samples of water from drinking fountains and sinks used for coffee preparation and ice from ice machines are digested with nitric acid. Total lead is quantitated using graphite furnace atomic absorption spectroscopy at $283.3 \mathrm{~nm}$; total copper, using flame $A A$ at $324.8 \mathrm{~nm}$.
\end{abstract}

\section{APPLICATIONS AND LIMITATIONS}

The current action level for lead in drinking water is 15 PPB, requiring the use of graphite furnace AA for detection. Using this procedure, the detection limit for lead is .005 PPB. The higher action level for copper, 1.3 PPM, permits the use of flame AA, having a detection limit of. 001 PPM. (The indicated detection limits are published values. Varying the sample preparation techniques and/or analytical conditions can improve the quantitation limits.)

\section{APPARATUS}

Polyethylene bottles, $1000 \mathrm{ml}$, standard or I-Chem Protocol C

Atomic absorption spectrophotometer - Perkin-Elmer Model 6500 with computer data acquisition, for graphite furnace analysis of lead

Graphite furnace - Perkin-Elmer Model 500

Autosampler - Perkin-Elmer Model AS-40

Recorder - Perkin-EImer Model 56

Electrodeless discharge lamp for Lead

Atomic absorption spectrophotometer - Perkin-Elmer Model

703, for flame AA analysis of copper

Hollow cathode lamp for Copper

Beakers, $150 \mathrm{ml}$, with watchglass covers

Graduated cylinders, $25 \mathrm{ml}$

Hot plate 


\section{REAGENTS}

Nitric acid, conc. $\left(70 \% \mathrm{HNO}_{3}\right)$, J.T. Baker Ultrex

Nitric acid, $1: 1$

Stock standards (1000 $\mu \mathrm{g} / \mathrm{ml})$ - A commercially-prepared stock standards in nitric acid are used.

Lead working standards - Prepare working standards of between 10 and $100 \mathrm{ng} / \mathrm{ml}$. These standards will be acidified to the same strength as the stock standard using Ultrex nitric acid. STANDARDS SHALL BE REMADE EVERY DAY.

Copper working standards - Prepare working standards of 1 , 2 , and $5 \mu \mathrm{g} / \mathrm{ml}$. These standards will be acidified to the sume strength as the stock standard using Ultrex nitric acici.

\section{SAMPLING PROCEDURE}

1. Standard polyethylene bottles may be used for routine water analyses. Eor drinking water surveys, use I-Chem Protocol C bottles, which have been cleaned using an EPA protocol. Alternatively, standard sample bottles may be used after cleaning according to the EPA protocol.

2. The sample size will be $1000 \mathrm{ml}$, taken as a first draw from the water fountain, sinkk or ice machine after standing for at least 6 hours. Run water down the inside of the bottle to prevent splashing of the acid, leaving an air gap of approximately $1 / 2$ " from the bottom of the bottle neck. To sample an ice machine, grab ice with a disposable plastic glove; fill the sample bottle with ice; and discard the plastic glove.

3. Acidify the samples to $\mathrm{pH}<2$ with $4 \mathrm{ml}$ of $1: 1 \mathrm{HNO}_{3}$, added either before or after collection.

4. Close the bottle firmly and agitate after filling. Seal and label appropriately.

\section{ANALYTICAL PROCEDURE}

1. Before digestion, a l-m] aliquot of each sample will be screened for approximate lead content. These results will determine the volume of sample to be digested.

2. If the sample is to be split with a reference laboratory, divide it into two $500-\mathrm{ml}$ samples, and reseal and relabel. 
Sample preparation

1. Beakers and graduated cylinders for use with this procedure shall be either new and unused or cleaned according to the following EPA protocol:

Wash with detergent and tap water.

Rinse with $1: 1$ nitric acid and deionized water.

2. Place $100 \mathrm{ml}$ of sample in a 150-ml beaker, and add $3 \mathrm{ml}$ of conc. $\mathrm{HNO}_{3}$. Evaporate cautiously on a hot plate to near dryness, being sure not to boil or bake.

3. Add additional aliquots of acid until the sample is dissolved and colorless. Cool the beaker, and add $1 \mathrm{ml}$ of 1: $1 \mathrm{HNO}_{3}$, warming slightly to dissolve any precipitate.

4. Transfer all remaining material to a 25-ml graduated cylinder, and dilute to volume.

Lead analysis

1. Set the autosampler programmer to the following parameters:

Sample volume - $20 \mu 1$

Number of standards - 3 or as applicable)

Last sample - as applicable

Delay time - 1 min

AA program number - 1 (or as applicable)

HGA program number - 1 (or as applicable)

4. Set the graphite furnace programmer to the following parameters:

Step 1 (Dry) - $130{ }^{\circ} \mathrm{C}$, ramp $5 \mathrm{sec}$, hold $30 \mathrm{sec,} \mathrm{gas} \mathrm{flow}$ $300 \mathrm{ml} / \mathrm{min}$

Step 2 (Char) - $500{ }^{\circ} \mathrm{C}$, ramp 5 sec, hold $20 \mathrm{sec}$, gas flow $300 \mathrm{ml} / \mathrm{min}$

Step 3 (Atomize) - $2100{ }^{\circ} \mathrm{C}$, ramp 0 sec, hold 5 sec, gas flow $50 \mathrm{ml} / \mathrm{min}$, recorder $-5 \mathrm{sec}$, read $-2 \mathrm{sec}$

Step 4 (Cool) - $40{ }^{\circ} \mathrm{C}$, ramp 1 sec, hold 4 sec, gas flow $300 \mathrm{ml} / \mathrm{min}$

Store as Program \#1 (or as applicable). 
5. Set the Model 6500 atomic absorption spectrophotometer to

the following parameters:

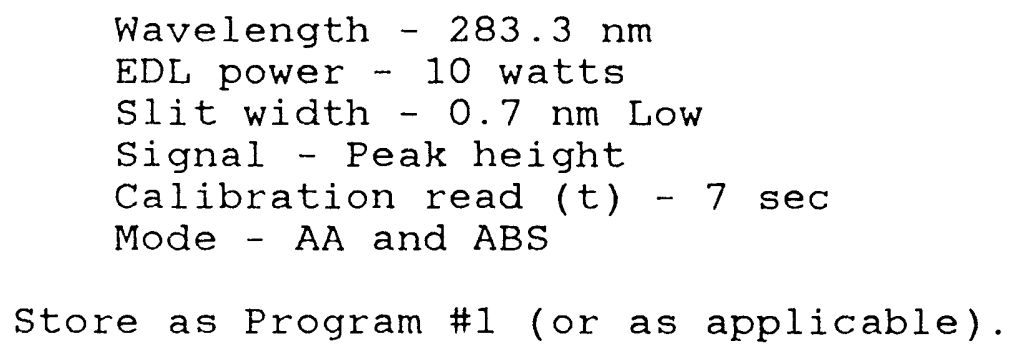

6. Place the standards, blanks, samples, and $Q A$ samples in the autosampler. Run the samples according to the manufacturer's instructions.

7. Calculate the concentrations using the "CURVE" program on the STANDARD PAC disk for the Hewlett-Packard HP-85 calculator.

\section{Copper analysis}

1. Copper analyses of the digested sample will be run on the Model 703 flame atomic absorption spectrophotometer.

2. The procedure will be that listed in "General Procedures for Atomic Absorption Spectroscopy," Section B of this Manual.

\section{QUALITY ASSURANCE}

1. A reagent blank, consisting of at least $0.5 \%$ Ultrex nitric acid in distilled water, shall be run at the beginning of each sample set and after each high standard to check for memory effects.

2. A medium-range standard shall be rerun after every 20 samples, or at least once per sample set.

3. One sample out of 20 , or at least one per sample set shall be divided prior to sample prenaration and run as replicates to check precision.

4. One sample out of 20 , or at least one per sample set shall be divided, one-half to be spiked at the regulatory level and run to check matrix effects on recovery and precision.

4. $10 \%$ of the samples shall be divided and run as splits with a reference laboratory. 


\section{REFERENCES}

1. Analytical Methods for Eurnace Atomic Absorption Spectroscopy, Publication No. 0303-0512 (Norwalk, CT: The Perkin-Elmer Corp., 1982)

2. AS-40 Auto Sampler Sequencer Version Operator's Manual, Publication No. B347-A1-M509/3.82 (West Germany: The PerkinElmer Corp., 1982)

3. HGA Graphics II Software Package Instructions, Publication No. NO65-0038 (Norwalk, CT: The Perkin-Elmer Corp., 1984)

4. Methods for Chemical Analysis of Water and Wastes, Publication No. EPA-600/4-79-020 (Cincinnati, OH: U.S. Environmental Protection Agency, 1983), Section 200.0 Atomic Absorption Methods for Metals, Method 239.2 Lead.

Reviewed by:

Reviewed by:

Reviewed by:

Reviewed by:

Reviewed by:
Review date:

Review date:

Review date:

Review date:

Review date: 


\section{LEAD IN URINE}

\section{ABSTRACT}

Small quantities of lead in urine can be analyzed using Anodic stripping Voltammetry (ASV). This electrochemical technique involves (1) preconcentrating the sample by forming an amalgam with a thin-film mercury electrode, and then (2) scanning the electrode potential to electrolytically dissolve the metal back into solution. The stripping current is proportional to the concentration of the analyte in the original sample. (See Reference 1 for a more complete description of the ASV technique.)

\section{APPLICATIONS AND LIMITATIONS}

Anodic stripping Voltammetry is primarily a trace analytical technique and is not generally recommended for analyte concentrations greater than 1 PPM. Using the Metexchange reagents (Environmental Sciences Associates, Inc.), the linear range for lead in urine is $10-750 \mu \mathrm{g} / \mathrm{L}$.

The presence of EDTA (used as a preservative in the sampling procedure) or Penicillamine in the samples can cause low lead recoveries. The effects of these interferences are mitigated by the addition of nickel or copper, respectively. The extreme sensitivity of the technique requires the use of high purity chemicals for all additional processing.

\section{APPARATUS}

Anodic Stripping Voltammeter, Fnvironmental Sciences Associates (ESA) Model 3010A

Metexchange "U" Reagent Kit, from ESA, Inc., containing all the necessary reagents, standards, and equipment for the ASV analysis of lead in urine

Electrode resurfacing tool

pH Paper.

Pipettes, $100 \mu \mathrm{l}$ and $1 \mathrm{ml}$

Steel wool for cleaning the electrode 


\section{REAGENTS}

Hydrochloric acid, reagent grade

\section{ANALYTICAL PROCEDURE}

\section{Instrument preparation}

1. Condition the electrode before each day's run. Remove the stirring rod, and clean the electrode, using steel wool wrapped around the resurfacing tool. Rinse with distilled water, and replace the stirring rod. Place a tube of the mercury plating solution (red dot tube from either Reagent $\mathrm{Kit}$ ) over the electrode, and run three 1-minute analytical cycles to lay down a thin film of mercury. The plating solution can be reused several times. (Eor detailed instructions, see Reference 2.)

2. Adjust the parameter settings as indicated for the individual sample types.

3. Adjust the Blank Correction Dial by placing a Lo Level Control tube (blue dot tube from the Reagent Kit) on the cell head. Be sure to rock the tube gently (do not shake) several times before uncapping to assure that the reagent is well mixed. Record the digitally-displayed concentration, and repeat the run with a separate control tube until 2 consecutive concentrations differ by 5 or less for urine standards, 4 or less for blood standards. Average the last 2 values, subtract the assigned Lo Level Control value (listed on the reagent box), and adjust the Blank Correction Dial for the difference.

4. Adjust the Calibration Control Dial by placing a Hi Level Control tube (green dot tube from the Reagent kit) on the cell head. Be sure to rock the tube gently (do not shake) several times before uncapping to assure that the reagent is well mixed. Record the digitally-displayed concentration. Calculate the optimum dial setting using the following formula:

$$
\begin{gathered}
\text { Setting }=\frac{\text { Assigned control value (on box) }}{\text { Digital reading }} \times \text { Dial setting } \\
\text { used }
\end{gathered}
$$

Adjust the Calibration Control Dial, rinse the electrode with a used Lo Level control, and repeat the analysis with a second Hi Level control. Repeat the entire procedure if the second reading is not within \pm 10 of the assigned value for urine, \pm 5 for blood. 
Urine samples

1. Set the analytical parameters to the values recommended in Reference 3 .

2. Calibrate the instrument as in the "Instrument preparation" section.

3. Acidify the homogenized urine sample to $\mathrm{pH}$ 3-5 with reagentgrade $\mathrm{HCl}$. (Use $\mathrm{pH}$ paper rather than a $\mathrm{pH}$ electrode to avoid potential contamination of the sample.) Pipette $1 \mathrm{ml}$ of urine into a reagent tube supplied with the Metexchange "U" Kit, and allow 5 minutes for equilibration.

4. Place the tube on the cell head, stir the sample for 5 seconds, depress the START ANALYSIS Switch, and record the concentration when the READY light appears (150 seconds analysis time).

5. Check the validity of the calibration after 20 samples or at the end of each series.

6. At the end of the day, replace the sample tube with a previously-run Lo Level Control sample (or distilled water, if the instrument will not be used in the next few days).

\section{REEERENCES}

1. W.M. Peterson and R.V. Wong, "Fundamentals of stripping Voltammetry," Am Lab 13(11):116 (1981).

2. Model 3010A trace Metals Analyzer Instruction Manul (Bedford, MA: Environmental Sciences Associates, Inc., 1987).

3. "Direct Analysis of Lead in Urine Using Metexchange ' $U$ ' Reagent with No Sample Pretreatment," Publication No. TMA-2, Methods Manual for ESA 3010A Anodic Stripping Voltammeter (Bedford, MA: Environmental Sciences Associates, Inc.).

Reviewed by:

Reviewed by:

Reviewed by:

Reviewed by:

Reviewed by:
Review date:

Review date:

Review date:

Review date:

Review date: 
THIS PAGE INTENTIONALLY LEFT BLANK

$\bar{B}-7 \bar{U}$ 


\section{MERCURY IN URINE}

\section{ABSTRACT}

Urine samples are decomposed with nitric acid, and then the mercury is reduced to the elemental state with stannous chloride. The mercury vapor is passed through an absorption cell with quartz end windows and then analyzed by atomic absorption using the $253.7 \mathrm{~nm} \mathrm{Hg}$ resonance line. (See also "General Procedures for Atomic Absorption Spectroscopy," Section B of this Manual.)

\section{APPLICATIONS AND LIMITATIONS}

The sensitivity for a $1.0-\mathrm{ml}$ urine sample is $3 \mu \mathrm{g} / \mathrm{L}$. The range extends up to $0.3 \mathrm{mg} / \mathrm{L}$.

Metals such as copper, gold, or platinum form alloys with mercury and thus will cause a negative response. Water vapor or organic solvents that absorb at $253.7 \mathrm{~nm}$ cause a positive response. Another limilation to this method is that some organic mercury compounds are not decomposed by the cold digestion technique.

\section{APPARATUS}

Atoric absorption spectrophotometer, Perkin-Elmer Model 703

High-efficiency bubbler, 100-ml size

Mercury evolution train - This consists of a rotometer covering the 0 to $5 \mathrm{~L} / \mathrm{min}$ range, a high-efficiency bubbler, a midget impinger as a safety trap, a drying tube filled with magnesium perchlorate, and the absorption cell. All components are connected to an air supply line with minimum lengths of Tygon tubing.

Pipets, 1-, 2-, and 5-ml sizes

Volumetric flask, $1000 \mathrm{ml}$

\section{REAGENTS}

Nitric acid, conc. $\left(70 \% \mathrm{HNO}_{3}\right)$

n-octyl alcohol

Hydrochloric acid $(6 \mathrm{~N})$ - Add $500 \mathrm{ml}$ of conc. HCl to $500 \mathrm{ml}$ of distil.'ed water. 
Stannous chloride solution, $20 \%$ (w/v) in $6 \mathrm{~N} \mathrm{HCl} \mathrm{-} \mathrm{Dissolve}$ $10 \mathrm{~g}$ of stannous chloride in $50 \mathrm{ml}$ of $6 \mathrm{~N} \mathrm{HCl}$.

Mercury stock standard (1000 $\mu \mathrm{g} \mathrm{Hg} / \mathrm{ml})$ - A commerciallyprepared stock standard in nitric acid is used.

Mercury working standard $(1 \mu \mathrm{g} \mathrm{Hg} / \mathrm{ml})$ - Pipet $1 \mathrm{ml}$ of the $1000-\mu \mathrm{g} / \mathrm{ml}$ stock standard into a $1-1$ iter volumetric flask. Add $20 \mathrm{ml}$ of conc. $\mathrm{HNO}_{3}$, and dilute to volume with distilled water. PREPARE ERESH DAILY.

\section{ANALYTICAL PRCCEDURE}

1. Transfer $2 \mathrm{ml}$ of urine to a high-efficiency bubbler.

2. Add $5 \mathrm{ml}$ of $\mathrm{HNO}_{3}$, and allow it to react at room temperature for at least 3 minutes.

3. Dilute to $50 \mathrm{ml}$ with distilled water. Add 3 drops of $\mathrm{n}$ octyl alcohol as a surfactant and $1 \mathrm{ml}$ of stannous chloride solution, and connect the flask to the bubbler tube in the genesating train.

4. Open the air valve, and pass air through the train at a rate of $2 \mathrm{~L} / \mathrm{min}$.

5. Record the detector reisponse on the recirder.

6. Run standards of 0.001 to $1 \mu \mathrm{g} \mathrm{Hg}$ in the same manner, rinsing the pipet in the solution. Different standard quantities of $\mathrm{Hg}$ can be added to the same standard solution since the $\mathrm{Hg}$ is completely removed during the reaction.

\section{CALCULATIONS}

1. Make a calibration curve by plotting peak height or area under the curve versus $\mu \mathrm{g} \mathrm{Hg}$ on semilog graph paper.

2. Erom the calibration curve, read $\mu \mathrm{g} \mathrm{Hg}$ for each of the samples.

3. Hg concentration $(\mu \mathrm{g} / \mathrm{ml})=\frac{\mu \mathrm{g} \text { Hg found }}{\mathrm{ml} \text { sample taken }}$

4. Alternatively, the concentration may be calculateci using the "CURVE" program on the STANDARD PAC disk for the HewlettPackard HP-85 calculator. 


\section{REEERENCES}

1. W.R. Hatch and W.L. Ott, "Determination of Sub-Microgram Quantities of Mercury by Atomic Absorption Spectrophotometry," Anal Chem 40:2085 (1968).

2. "Determination of Mercury in Urine," Methods of Air Sampling and Analysis, ed J.P. Lodge, Jr. (3rd ed; Chelsea, MI: Lewis Publishers, 1989), Method 815.

Reviewed by:

Reviewed by:

Reviewed by:

Reviewed by:

Reviewed by:
Review date:

Review date:

Review date:

Review date:

Review date: 
THIS PAGE INTENTIONALLY LEFT BLANK 


\section{NITROGEN DIOXIDE IN AIR}

\section{ABSTRACT}

Nitrogen dioxide is collected in sulfanilic acid. The diazotized $\mathrm{NO}_{2}$ is coupled with $\mathrm{N}$-(1-naphthyl)-ethylenediamine, forming a redviolet azo dye. The dye color is read at $550 \mathrm{~nm}$.

\section{APPLICATIONS AND LIMITATIONS}

The analytical range of this method is 0.005 to 5 PPM by volume or 0.01 to $10 \mu \mathrm{g} / \mathrm{L}$ when sampling with fritted bubblers. For greater accuracy, standardize using accurately-known gas samples rather than the more convenient nitrite solution.

The main limitations are due to interferences from larger concentrations of strong oxidizing and reducing agents, such as sulfur dioxide, hydrogen peroxide, ozone, and chlorine. Many of these interferences can be mitigated by the use of various chemical agents (see Reference 1) or by measuring the absorbance within 1 hour of sample collection.

\section{APPARATUS}

Spectrophotometer, Hewlett-Packard Model 8450A

Bubb!er, all-glass

Grab-sample bottles, 30- to 500-m1 sizes

Assorted laboratory glassware

\section{REAGENTS}

Sulfanilic acid, anhydrous

Acetic acid, glacial

N-(1-naphthyl)-ethylenediamine dihydrochloride $(0.1 \%)$ -

Dissolve $0.1 \mathrm{~g}$ of the salt in $100 \mathrm{ml}$ of distilled water. When stored in the refrigerator in a well-stoppered amber bottle, this reagent is stable for several months.

Absorbing reagent - Dissolve $5 \mathrm{~g}$ of sulfanilic acid in almost 1 liter of distilled water containing $140 \mathrm{ml}$ of glacial acetic acid. Add $20 \mathrm{ml}$ of a $0.1 \%$ solution of $\mathrm{N}$-(1-naphthyl)ethylenediamine dihydrochloride, and dilute to 1 liter. When stored in a brown bottle in the refrigerator, the reagent is stable for several months. Allow it to warm to room temperature before using. 
Sodium nitrite stock standard $(0.0203 \mathrm{mg} \mathrm{NaNO} / \mathrm{ml})$ - Add 2.030 $g$ of sodium nitrite to 1 liter of distilled water. This solution is stable for 90 days at room temperature and for 1 year when refrigerated in a brown bottle.

Sodium nitrite working standard (Equivalent to $10 \mu \mathrm{l} \mathrm{NO}_{2} / \mathrm{ml}$ ) -Prepare fresh by diluting $1 \mathrm{ml}$ of stock sodium nitrite solution to $100 \mathrm{ml}$. This solution of $0.0203 \mathrm{~g}$ of $\mathrm{NaNO}_{2}$ per liter is such that $1 \mathrm{ml}$ of this working standard, added to the absorbing reagent, produces a color equivalent to that of 10 $\mu 1$ of $\mathrm{NO}_{2}$ or 10 PPM of $\mathrm{NO}_{2}$ in 1 liter of air at STP.

\section{ANALYTICAL PROCEDURE}

For less than 1 PPM of $\mathrm{NO}_{2}$ :

1. Place $10 \mathrm{ml}$ of absorbing reagent in a fritted-glass bubbler.

2. Collect the sample at a $0.4-\mathrm{L} / \mathrm{min}$ rate for about 10 minutes or until sufficient red-violet color has developed.

3. Allow the color to develop for 15 minutes, transfer the sample to a cuvette, and read at $550 \mathrm{~nm}$ in the spectrophotometer. Use unexposed absorbing reagent to set instrument at zero absorbance.

For more than 1 PPM of $\mathrm{NO}_{2}$ :

1. Collect sample in an evacuated 250-ml or larger bottle containing $10 \mathrm{ml}$ of absorbing reagent. Shake the sample after collecting. Let set for 15 minutes.

2. Read at $550 \mathrm{~nm}$ after transferring the liquid containing the $\mathrm{NO}_{2}$ to a cuvette.

\section{CALIBRATION}

1. To eight $25-\mathrm{ml}$ volumetric flasks, add $0.05,0.10,0.20,0.30$, $0.40,0.50,0.60$, and $0.70 \mathrm{ml}$ of the working nitrite solution.

2. Dilute to $25 \mathrm{ml}$ with absorbing reagent and mix.

3. Allow the color to develop for 15 minutes, and then read at $550 \mathrm{~nm}$ against a zero of absorbing reagent. 
4. Plot the absorbances of the standards versus $\mu 1$ of nitrogen dioxide per ml of absorbing reagent. The latter values are equal to the corresponding $\mathrm{ml}$ of working nitrite solution times 0.4.* The plot follows Beer's Law. Through the origin draw a straight line giving the best fit, and determine the slope, $\mathrm{K}$, which is $\mu \mathrm{l}$ of $\mathrm{NO}_{2}$ intercepted at an absorbance of exactiy 1. For $1-\mathrm{cm}$ cells, the value of $\mathrm{K} \cong 0.73$.

\section{CALCULATIONS}

Compute the concentration of nitrogen dioxide in the sample using the following equation:

$$
\mathrm{PPM} \mathrm{NO}_{2}=\mathrm{AK} / \mathrm{V}
$$

where

$$
\begin{aligned}
& \mathrm{A}=\text { absorbance } \\
& \mathrm{K}=\text { slope of calibration curve } \\
& \mathrm{V}=\text { volume of air sampled in liters } / \mathrm{ml} \text { absorbing reagent }
\end{aligned}
$$

\section{REEERENCES}

1. B.E. Saltzman, "Colorimetric Microdetermination of Nitrogen Dioxide in the Atmosphere," Anal Chem 26:1949 (1954).

2. B.E. Saltzman, "Determination of Nitrogen Dioxide and Nitric Oxide: Saltzman Method," Selected Methods for the Measurement of Air Pollutants, Publication No. 999-AP-11 (Cincinnati, $\mathrm{OH}$ : U.S. Public Health Service, 1965), p. C-1.

3. "Determination of Nitrogen Dioxide Content of the Atmosphere (Griess-Sritzman Reaction)," Methods of Air Sampling and Analysis, ed J.P. Lodge, Jr. (3rd ed; Chelsea, MI: Lewis Publishers, 1989), Method 406.

* The molar volume at standard conditions of $760 \mathrm{~mm} \mathrm{Hg}$ and $25^{\circ} \mathrm{C}$ is 24.47 liters. One mole of nitrogen dioxide and 0.72 mole of sodium nitrite produce the same color. Since $1 \mathrm{ml}$ of the working solution contains $2.03 \times 10^{-5} \mathrm{~g}$ of $\mathrm{NaNO}_{2}$ (molecular weight $=69$ ), then

$\frac{2.03 \times 10^{-5}}{69} \times \frac{24.47}{0.72}=10^{-5}$ iiters of $\mathrm{NO}_{2}$ or $10 \mu 1$. Therefore $1 \mathrm{ml}$ of nitrite solution (10 $\left.\mu 1 \mathrm{NO}_{2}\right)$ per 25-ml volume is equivalent to $10 / 25$ or $0.4 \mu \mathrm{l}$ of $\mathrm{NO}_{2}$ per ml. 
Reviewed by:

Reviewed by:

Reviewed by:

Reviewed by:

Reviewed by:
Review date:

Review date:

Review date:

Review date:

Review date: 
(Colorimetric Method)

\section{ABSTRACT}

Air is drawn through a midget impinger containing $10 \mathrm{ml}$ of neutral potassium iodide solution. The ozone liberates iodine, which is determined colorimetrically at $352 \mathrm{~nm}$.

\section{APPLICATIONS AND LIMITATIONS}

This method is simple and rapid. The analytical range extends from 0.01 to $10 \mathrm{PPM}$. The sensitivity of the method is dependent on the volume of air sampled, and the analysis must be completed within 1 hour after sampling.

Main interferences are reducing compounds, such as sulfur dioxide, nitric oxide, and hydrogen sulfide. Some oxidants, such as halogens and hydrogen peroxide, will also interfere.

An alternative, non-instrumental technique uses titration of the liberated iodine using sodium thiosulfate (see "Ozone in Air (Titration Method," Section B of this Manual).

\section{APPARATUS}

Spectrophotometer, Hewlett-Packard Model 8450A

Midget impinger, all-glass

Assorted laboratory glassware

\section{REAGENTS}

Potassium dihydrogen phosphate

Disodium hydrogen phosphate, anhydrous

Potassium iodide

Absorbing reagent ( $1 \% \mathrm{KI}$ ) - Dissolve $13.61 \mathrm{~g}$ of potassium dihydrogen phosphate, $14.2 \mathrm{~g}$ of anhydrous disodium hydrogen phosphate, and $10 \mathrm{~g}$ of potassium iodide, in that order, in 1 liter of distilled water. Keep at room temperature for at least 1 day before using. Store in a brown bottle in a refrigerator. PREPARE MONTHLY. 
Iodine, resublimed

Iodine stock standard $\left(0.025 \mathrm{M} \mathrm{I}_{2}\right)$ - Dissolve successively $16 \mathrm{~g}$ of $\mathrm{KI}$ and $3.1730 \mathrm{~g}$ of iodine in $500 \mathrm{ml}$ of distilled water.

Keep at room temperature for at least 1 day before using.

Standardize with $0.10 \mathrm{~N}$ sodium thiosulfate shortly before use.

Iodine working standard $(0.00125 \mathrm{M} \mathrm{I})$ - Pipet $5 \mathrm{ml}$ of stock solution into a $100-\mathrm{ml}$ volumetric flask, and dilute to the mark with the absorbing reagent.

\section{ANALYTICAL PROCEDURE}

1. Pipet $10 \mathrm{ml}$ of absorbing reagent in the midget impinger.

2. After receiving the samples, measure the volume, and transfer to a clean cuvette. Do not dilute with rinse water!

3. Determine the absorbance of the yellow iodine solution at $352 \mathrm{~nm}$, using distilled water as the reference. Also determine the absorbance of a reagent blank.

4. Run a series of standards through steps 2 and 3 by pipetting $0.2-, 0.4-, 0.6-$, and $0.8-\mathrm{ml}$ portions of the working solution $\left(0.1,0.2,0.3\right.$, and $0.4 \mu$ moles $\mathrm{I}_{2} / 10 \mathrm{ml}$ of absorbing reagent) in separate 25-ml volumetric flasks. Dilute to the mark with absorbing reagent, $\mathrm{mix}$ well, and read the absorbance of each at $352 \mathrm{~nm}$.

5. Plot absorbance (after subtracting the absorbance of a reagent blank) versus molar concentration in $\mu$ moles $/ 10 \mathrm{ml}$.

\section{CALCULATIONS}

Since 1 mole of ozone liberates 1 mole of iodine, one can read umoles of ozone directly from the calibration curve, if the total sample volume is $10 \mathrm{ml}$. If the sample was diluted prior to analysis, the proper dilution factor must be included in the calculation.

PPM ozone $=$ umoles ozone $\times 24.47$ liters $/ \mathrm{mole}$ Volume of air sampled in liters at STP

\section{REEERENCES}

1. "Determination of Oxidizing Substances in the Atmosphere," Methods of Air Sampling and Analysis, ed J.P. Lodge, Jr. (3rd ed; Chelsea, MI: Lewis Publishers, 1989), Method 411. 
2. B.E. Saltzman, "Determination of Oxidants (Including Ozone: Neutral Buffered-Potassium Iodide Method," Selected Methods for the Measurement of Air Pollutants, Publication No. 999-AP11 (Cincinnati, OH: U.S. Public Health Service, 1965), p. D-1.

Reviewed by:

Reviewed by:

Reviewed by:

Reviewed by:

Reviewed by:
Review date:

Review date:

Review date:

Review date:

Review date: 
OZONE IN AIR

(Titration Method)

\begin{abstract}
Ozone is collected in KI solution; and the iodine liberated is titrated with sodium thiosulfate, using starch as an indicator.
\end{abstract}

\title{
APPLICATIONS AND LIMITATIONS
}

This method is a rapid and simple alternative to the colorimetric technique (see "Ozone in Air (Colorimetric Method)," Section B of this Manual) and uses no expensive equipment. The sensitivity is dependent on the volume of air sampled, making the technique especially good for larger concentrations of ozone.

The main limitation is that the liberated iodine is very sensitive to reducing vapors or dusts such as $\mathrm{SO}_{2}$ or $\mathrm{H}_{2} \mathrm{~S}$. Also, strong oxidants, such as halogens, peroxides, etc., will liberate iodine.

\section{ES\&H NOTES}

Chromates are designated as class A1 carcinogens by the ACGIH and Class 1 carcinogens by the IARC. Potassium dichromate should be handled in a Designated Area, typically a laboratory hood. The room and/or hood shall be clearly labeled with a sign indicating that a carcinogen is in use.

\section{APPARATUS}

Buret, 5-ml capacity

Magnetic stirrer, with Teflon-covered bar magnet Midget bubbler, all-glass

\section{REAGENTS}

\author{
Potassium iodide \\ Potassium iodide solution (5\%) - PREPARE FRESH DAILY. \\ Starch indicator solution - Dissolve $1 \mathrm{~g}$ of soluble starch in \\ $100 \mathrm{ml}$ of boiling distilled water. \\ Hydrochloric acid, $1: 1$ in distilled water
}


Potassium dichromate solution $(0.1 \mathrm{~N})$ - Dissolve $4.904 \mathrm{~g}$ of $\mathrm{K}_{2} \mathrm{Cr}_{2} \mathrm{O}$, (dried for 2 hours at $130^{\circ} \mathrm{C}$ ) in 1 liter of water.

Sodium bicarbonate

Sodium thiosulfate solution $(0.01 \mathrm{~N})$ - Dissolve $2.5 \mathrm{~g}$ of $\mathrm{Na}_{2} \mathrm{~S}_{2} \mathrm{O}_{3}-5 \mathrm{H}_{2} \mathrm{O}$ in 1 liter of distilled water. Standardize against $\mathrm{K}_{2} \mathrm{Cr}_{2} \mathrm{O}_{7}$ by the following method: Dissolve $5 \mathrm{~g}$ of $\mathrm{KI}$ and $4 \mathrm{~g}$ of $\mathrm{NaHCO}_{3}$ in $300 \mathrm{ml}$ of $\mathrm{H}_{2} \mathrm{O}$. Slowly add $1: 1 \mathrm{HCl}$ until no more $\mathrm{CO}_{2}$ is released; then add a 10-ml excess. Add $35 \mathrm{ml}$ of $0.1 \mathrm{~N} \mathrm{~K}_{2} \mathrm{Cr}_{2} \mathrm{O}_{7}$, and mix thoroughly. Add a stirring bar, and place on a magnetic stirrer. Titrate the stirred solution with thiosulfate to a light straw yellow. Add $1 \mathrm{ml}$ of starch indicator, and titrate intil the blue is replaced with the pale green color of $\mathrm{CrCl}_{3}$. Erom the volume of thiosulfate used, calculate the normality.

\section{ANALYTICAL PROCEDURE}

1. Collect samples in $10 \mathrm{ml}$ of freshly prepared KI.

2. Transfer the collecting solution to an Erlenmeyer flask, add a Teflon stirring bar, and place on a magnetic stirrer.

3. Add $1 \mathrm{ml}$ of $1: 1 \mathrm{HCl}$ and $1 \mathrm{ml}$ of starch indicator.

4. Titrate with standard thiosulfate to the colorless end point.

\section{CALCULATIONS}

$1 \mathrm{ml} 0.01 \mathrm{~N} \mathrm{Na}_{2} \mathrm{~S}_{2} \mathrm{O}_{3}=0.24 \mathrm{mg}$ ozone

\section{REEERENCES}

1. D.H. Beyers and B.E. Saltzman, "Determination of Ozone in Air by Neutral and Alkaline Iodide Procedures," Am Ind Hyg Assoc J $19: 251$ (1958).

Reviewed by:

Reviewed by:

Reviewed by:

Reviewed by:

Reviewed by:
Review date:

Review date:

Review date:

Review date:

Review date: 


\section{ABSTRACT}

Sulfur dioxide is collected in a midget impinger containing hydrogen peroxide, which converts the $\mathrm{SO}_{2}$ to sulfuric acid. The quantity of sulfuric acid absorbed is determined by ion chromatography.

\section{APPLICATIONS AND LIMITATIONS}

The quantitative detection limit for the method is $0.017 \mathrm{mg} / \mathrm{m}^{3}$ for a $60 \mathrm{~L}$ air sample. The limit of quantitation is $0.042 \mathrm{mg} / \mathrm{m}^{3}$ with a relative standard deviation of less than 0.10 .

Particulate sulfate compounds and sulfuric acid will interfere with the analysis but can be removed by use of a prefilter. Sulfur trioxide gas will also give a positive interference.

\section{APPARATUS}

Midget impinger, fritted glass

Ion chromatograph, Dionex Model $2110 i$ with electrolytic conductivity detector

Integrator, Hewlett-Packard Model 3390A or 3396A

Syringes, liquid, $5 \mathrm{cc}$, plastic

\section{REAGENTS}

Hydrogen peroxide $(0.3 \mathrm{~N})$ - Dilute $17 \mathrm{ml}$ of $30 \% \mathrm{H}_{2} \mathrm{O}_{2}$ to 1 liter with distilled water.

Eluent solution, $0.0029 \mathrm{M} \mathrm{NaHCO} / 0.0023 \mathrm{M} \mathrm{Na}_{2} \mathrm{CO}_{3}-$ Dissolve $0.9744 \pm 0.0005 \mathrm{~g}$ of $\mathrm{NaHCO}_{3}$ and $0.9752 \pm 0.0005 \mathrm{~g}$ of $\mathrm{Na}_{2} \mathrm{CO}_{3}$ in 4 liters of distilled water.

Regenerant solution, $0.025 \mathrm{~N} \mathrm{H}_{2} \mathrm{SO}_{4}-$ Dilute $2.8 \mathrm{ml}$ of concentrated $\mathrm{H}_{2} \mathrm{SO}_{4}$ to 4 liters with distilled water.

Sulfate stock standard $\left(1000 \mu \mathrm{g} / \mathrm{ml} \mathrm{SO}_{4}^{-}\right)-$Dissolve and dilute $1.4792 \mathrm{~g}$ of $\mathrm{Na}_{2} \mathrm{SO}_{4}$ to 1 liter with distilled water.

Sulfate working standards - Prepare standards in the range of $1-100 \mu \mathrm{g} / \mathrm{ml}$. PREPARE FRESH MONTHLY, OR WEEKLY IF BELOW $50 \mu \mathrm{g} / \mathrm{ml}$. 


\section{ANALYTICAL PKOCEDURE}

1. Collect the sample in a midget impinger containing $15 \mathrm{ml}$ of $0.3 \mathrm{~N}$ hydrogen peroxide.

2. Measure and record the total volume of each sample before analysis.

3. Set up the ion chromatograph and run the samples and standards as described in "Common Anions in Aqueous Solutions," Section B of this Manual. The retention time for the sulfate anion will be approximately 18 minutes at a flow rate of $138 \mathrm{ml} / \mathrm{hr}$.

\section{CALCULATIONS}

1. Calculate a calibration factor for the sulfate anion:

$\mathrm{CF}=$ Peak area for standard / $\mu \mathrm{g}$ sulfate in standard

2. Calculate the sulfate concentration for the samples: $\mu \mathrm{g}$ Sulfate $=$ Peak area for sample $\times \mathrm{CF}$

3. Convert sulfate concentration to $\mathrm{SO}_{2}$ concentration: $\mu \mathrm{g} \mathrm{SO}_{2}=\left(\mu \mathrm{g} \mathrm{SO}_{4}^{-}\right) \times(0.667) \times($ Total sample volume) where 0.667 is the gravimetric ratio of $\mathrm{SO}_{2} / \mathrm{SO}_{4}^{-}$.

\section{REEERENCES}

1. "Sulfur Dioxide in Workplace Atmospheres (Impinger)," OSHA Analytical Methods Manual (Salt Lake City, UT: Occupational Safety and Health Administration, 1985), Method ID-104.

2. "Determination of Sulfur Dioxide Content of the Atmosphere (Hydrogen Peroxide Method)," Methods of Air Sampling and Analysis, ed J. P. Lodge, Jr. (3rd ed; Chelsea, MI: Lewis Publishers, 1989), Method 704C.

Reviewed by:

Reviewed by:

Reviewed by:

Reviewed by:

Reviewed by:

$$
\begin{aligned}
& \text { Review date: } \\
& \text { Review date: } \\
& \text { Review date: } \\
& \text { Review date: } \\
& \text { Review date: }
\end{aligned}
$$


ABSTRACT

Urine samples are diluted with a matrix modifier and analyzed at $276.8 \mathrm{~nm}$ using graphite furnace atomic absorption spectroscopy. (See also "General Procedures for Atomic Absorption Spectroscopy," Section B of this Manual.)

\section{APPLICATIONS AND LIMITATIONS}

This technique allows the direct determination of thallium in urine, avoiding time-consuming extraction techniques and the use of organic solvents. With background correction, a detection limit of $0.5 \mathrm{ng} / \mathrm{ml}$ can be achieved. Precision is $15 \%$ at 6 $\mathrm{ng} / \mathrm{ml}$. The AA sensitivity (amount of material giving an absorbance of 0.0044 ) is calculated to be $35 \mathrm{pg}$.

\section{APPARATUS}

Atomic absorption spectrophotometer - Perkin-Elmer Model 6500

Graphite furnace - Perkin-Elmer Model HGA 500

Autosampler - Perkin-Elmer Model AS-40

Recorder - Perkin-Elmer Model 56

Electrodeless discharge lamp for Thallium

Centrifuge tubes, 40-ml plastic

\section{REAGF.NTS}

Magnesium nitrate hexahydrate $\left(\mathrm{MgNO}_{3} \cdot 6 \mathrm{H}_{2} \mathrm{O}\right)$

Nitric acid, conc. $\left(70 \% \mathrm{HNO}_{3}\right)$

Titon $\mathrm{X}-100$, scintillation grade

Matrix modifier - Dilute $1.0 \mathrm{~g} \mathrm{MgNO}_{3} \cdot 6 \mathrm{H}_{2} \mathrm{O}, 4.0 \mathrm{ml}$ conc. $\mathrm{HNO}_{3}$, and $0.01 \mathrm{ml}$ Triton $\mathrm{X}-100$ to $100 \mathrm{ml}$ with dj.stilled water.

Hydrochloric acid (4N) - Add $333 \mathrm{ml}$ of conc. $\mathrm{HCl}$ to $667 \mathrm{ml}$ of distilled water. 
Thallium stock standard (1000 $\mu \mathrm{g} \mathrm{Tl} / \mathrm{ml})$ - Available commercially, or prepare by dissolving $1.1174 \mathrm{~g}$ of thallic oxide in 1 liter of $4 \mathrm{~N} \mathrm{HCl}$.

Thallium working standard ( $1 \mu \mathrm{g} \mathrm{Tl} / \mathrm{ml})$ - Dilute $100 \mu \mathrm{l}$ of $1000-\mu \mathrm{g} / \mathrm{ml}$ stock standard to $100 \mathrm{ml}$ with distilled water.

Pooled urine sample

Thallium stock standard in urine (20 ng $\mathrm{Tl} / \mathrm{ml})$ - Dilute 0.2 $\mathrm{ml}$ of $1-\mu \mathrm{g} / \mathrm{ml}$ working standard to $10 \mathrm{ml}$ with pooled urine.

Thallium working standard in urine (10 $\mathrm{ng} \mathrm{Tl} / \mathrm{m} 1$ ) - Dilute 1 $\mathrm{ml}$ of $20-\mathrm{ng} / \mathrm{ml}$ stock urine standard with $1 \mathrm{ml}$ of matrix modifier.

\section{ANALYTICAL PROCEDURE}

1. Set up the autosampler and spectrophotometer as described in "Total Lead and Copper in Drinking Water Fountains," Section $B$ of this Manual, with the following differences:

Wavelength - $276.8 \mathrm{~nm}$

EDL power - 7 watts

2. Set the graphite furnace programmer to the following parameters:

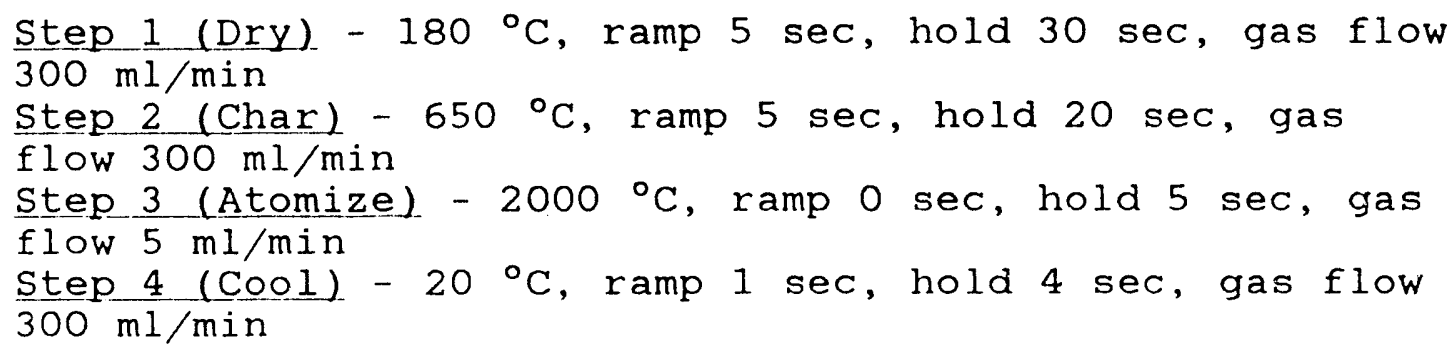

3. Combine $1 \mathrm{ml}$ of sample urine and $1 \mathrm{ml}$ of matrix modifier in a 40-ml centrifuge tube. Agitate to mix.

4. Place the standards, blanks, samples, and QA samples in the autosampler. Run the samples according to the manufacturer's instructions.

4. Calculate the concentrations using the "CURVE" program on the STANDARD PAC disk for the Hewlett-Packard HP-85 calculator. 


\section{REFERENCES}

1. D.C. Paschal and G.G. Bailey, "Determination of Thallium in Urine with Zeeman Effect Graphite Furnace Atomic Absorption," J Anal Toxicology 10 (Nov/Dec):252 (1986).

Reviewed by:

Reviewed by:

Reviewed by:

Reviewed by:

Reviewed by:
Review date:

Review date:

Review date:

Review date:

Review date: 


\section{THIS PAGE INTENTIONALLY LEFT BLANK}




\section{SECTION C}

\section{ORGANIC METHODS}




\section{THIS PAGE INTENTIONALLY LEFT BLANK}




\section{COMPOSITION OF COMMERCIAL AND PROPRIETARY PRODUCTS}

\section{ABSTRACT}

A certain percentage of the laboratory workload is analysis of commercial or proprietary products to determine potential toxic hazards. The chemist may be asked to determine the composition of a solvent free from solids, or he may be given a resin solution or a paint and asked to determine the solvent in which the solid material is dissolved or suspended.

Through his experience and academic training, an analytical chemist has usually gathered a large mental file of information useful in recognizing a compound's characteristics and in evaluating those characteristics. The actual analysis of an unknown almost invariably proceeds on the basis of these value judgments via well-known schemes toward qualitative and quantitative determination of composition.

\section{THE ANALYSIS PROCESS}

\section{Gathering Initial observations}

Many times the major component of a product can be assumed or inferred from one or more of the following easily gathered sources of information:

1. Name: Usually a trade name, but sometimes it gives a helpful hint toward the major component.

Example: Tellurac (R. T. Vanderbilt Co.) is an organic salt of tellurium.

Liqui-Moly (Lockrey Co.) is a molybdenum sulfide lubricant.

Thiofact (National Aniline Div., Allied Chemical Corp.) is a sulfur-containing indigo pigment.

2. Source: Sometimes useful in characterizing chemical class.

Example: Shell Chemical Co. is famous for petrochemicals; thus, a shell product is most likely an organic chemical and amenable to infrared and/or gas chromatrographic analysis. 
Pennsylvania Glass Sand Corp. products would almost certainly contain silica as a major ingredient.

Thiokol Chemical Corp. is famous for its polysulfide-based rubber formulations.

3. Use: Often very helpful in determining chemical class.

Example: Typewriter roller cleaners are used to dissolve inks, so they are usually low-boiling-point organic solvents or solvent mixtures.

Gunpowder solvents almost always contain nitrobenzene or some other nitro product.

Bactericides and algicides for water treatment often contain quaternary ammonium salts amenable to infrared analysis.

4. Physical characteristics: Usually very helpful but possibly misleading. Practically all industrial products are secret formulations purposely doctored in some way to disguise the major constituents and active ingredients.

a. Physical state is the most easily noted physical charactistic and one of the most difficult to mask. It must be remembered, however, that an emulsifying, wetting, or gelling agent can alter the physical state from an immiscible to a miscible liquid, from a suspension to a colloid, or from a liquid to a solid.

r. Color is only rarely helpful. Most manufacturers use coloring agents as disguises only too successfully. The very distinctive fluorescent green of fluorescein is evident in a multitude of products from household liquid detergents to industrial leak detectors. In none of these products is fluorescein of any functional use whatsoever.

c. Smell can often lead to an immediate value judgment for the major component. A sulfur-containing material often smells like $\mathrm{H}_{2} \mathrm{~S}$ (rotten eggs) or $\mathrm{SO}_{2}$ (burnt matches). Amines smell fishy; esters and higher ketones, fruity; aldehydes, musty.

d. Other physical characteristics such as density, melting and boiling points, and index of refraction should not be determined at this point unless a specific compound is already highly suspect. 
5. Chemical characteristics: These are the most significant properties, yielding the most useful data. The single most important consideration when analyzing a commercial product for its constituents is to approach it step by step, proceeding from the simple to the more complex tests in a meaningful fashion. Many such schemes appear in the literature for both inorganic and organic qualitative analysis.

a. Reaction in a Bunsen-burner flame: If a product burns completely, boils away, smokes, or chars in a flame, it is at least partially organic. If it leaves a residue or ash, it is at least partially inorganic. The color of the flame above the sample often indicates which alkali metal is present.

b. Solubility: Although this is, strictly speaking, a physical characteristic, it is a most helpful indicator of chemical composition. Try water, alcohol, and petroleum ether as "indicator" solvents. If the product is soluble or partially soluble in water, determine the $\mathrm{pH}$; then make the solution acidic and then basic, and observe for precipitation, gas evolution, or change in color.

c. Reducing ability: Using one portion of the acidified solution from step (b), add 1 drop of $1 \% \mathrm{KMnO}_{4}$ to test for reducing agents.

d. Oxidizing ability: To another portion of the acidified solution from step (b) above, add 5 drops of a $10 \% \mathrm{KI}$ starch solution to test for oxidizing agents.

e. Metals content: Use atomic absorption or inductively coupled plasma (ICP) spectroscopy to determine metals in a solution.

f. Liquid purity and quantitation: Use the gas chromatograph to determine the number of components in an organic liquid. The resulting gas chromatogram not only indicates the number of low-to-medium boiling fractions quickly and accurately, but also can be saved for future quantitation. Note also the shape of the peak -- a long "tail" can indicate a polar or nonpolar compound, depending upon the column used.

g. Water content: Add a pinch of anhydrous copper sulfate, shake, and observe the color. If water is present, the white anhydride turns blue. Of course, all water solutions react in this way, but so will water in minor amounts in organic mixtures. This test is most helpful in determining amenability to later infrared analysis using $\mathrm{NaCl}$ windows. 
6. Solvents: Since a substantial percentage of most commercial products is the solvent, a detailed discussion is presented here. Solvents vary widely; but, in general, the following rules hold:

a. The lower molecular weight alcohols, ketones, and esters are soluble, to varying degrees, in water. All of these except methanol, ethylene glycol, and glycerine can be separated by saturating the water solution with $\mathrm{NaOH}$ or $\mathrm{NaCl}$.

b. The water-insoluble alcohols, esters, ketones, ethers, and unsaturated hydrocarbons are soluble in $80 \% \mathrm{H}_{2} \mathrm{SO}_{4}$ ( $80 \mathrm{ml}$ of conc. $\mathrm{H}_{2} \mathrm{SO}_{4}$ diluted to $100 \mathrm{ml}$ with water). An $80: 20$ mixture of $\mathrm{H}_{2} \mathrm{SO}_{4}$ and $\mathrm{H}_{3} \mathrm{PO}_{4}$ gives essentially the same solubility. Dilution of the acid layer to 3 or 4 times the original volume, followed by addition of $\mathrm{Na}_{2} \mathrm{SO}_{4}$, causes all of these except the unsaturated hydrocarbons to come out of solution with either reagent. The $\mathrm{H}_{3} \mathrm{PO}_{4}$ lessens hydrolysis of esters.

c. Aromatic hydrocarbons are almost insoluble in $80 \% \mathrm{H}_{2} \mathrm{SO}_{4}$, but the solubility increases with the number of alkyl groups. Aliphatic hydrocarbons and halogenated aliphatic hydrocarbons are insoluble in $80 \% \mathrm{H}_{2} \mathrm{SO}_{4}$. Trichloroethylene and perchloroethylene, even though they are double bonded, are not soluble in $80 \% \mathrm{H}_{2} \mathrm{SO}_{4}$

d. Aromatic hydrocarbons and halogenated aromatic hydrocarbons are soluble in fuming $\mathrm{H}_{2} \mathrm{SO}_{4}$ (30-33\% free $\mathrm{SO}_{3}$ ).

e. The aliphatic hydrocarbons and halogenated aliphatic hydrocarbons are insoluble in fuming $\mathrm{H}_{2} \mathrm{SO}_{4}$, unless they are highly branched. Trichloroethylene and perchloroethylene are slowly soluble in fuming $\mathrm{H}_{2} \mathrm{SO}_{4}$.

f. The refractive intercept, calculated by subtracting onehalf of the specific gravity from the refractive index, gives an indication of the type of hydrocarbon present. The value of the refractive intercept is about 1.0640 for al 1 common aromatic hydrocarbons and 1.0460 for all chain aliphatic hydrocarbons. The cyclic aliphatic hydrocarbons have a refractive intercept close to 1.0400 .

g. A low refractive intercept indicates a greater specific gravity compared to the refractive index. This value cannot be used to identify types of solvents other than hydrocarbons, since the value varies for each alcohol, ketone, ester, and halogenated hydrocarbon. 
h. The dispersion gives an indication of the presence of aromatic hydrocarbons. The $Z$ value on the scale of the Abbe refractometer (manufactured by Bausch \& Lomb) is about 23 or 24 for aromatic hydrocarbons, whereas other solvents usually give 17, 18, or 19. On the Zeiss Abbetype refractometer, the aromatic hydrocarbons give a reading of about 35 ; and other solvents, a reading of about 41 .

i. Aromatic hydrocarbons have a specific gravity close to 0.87 and a refractive index close to 1.50 .

\section{Analysis}

When steam distillation is necessary, the water and solvent layers are separated. The cerate test for alcohols (described later) is run on the water layer. If this test is positive and methanol is thought to be present, test the layer for methanol, as described later under "Test for Methanol."

Any other components usually found in solvents can be separated from the water layer by saturating the water with $\mathrm{NaOH}$ or $\mathrm{NaCl}$.

Add any solvent recovered from the water layer to the solvent layer, and dry the solvent thoroughly by adding anhydrous $\mathrm{Na}_{2} \mathrm{SO}_{4}$. Allow the solvent to stand overnight. Drying is necessary, since many solvents form azeotropes with water. Alternatively, the water which distills over may be soluble in some of the components, thereby changing the constants.

Solvents which do not require steam distillation are also dried over anhydrous $\mathrm{Na}_{2} \mathrm{SO}_{4}$.

Distill $100 \mathrm{ml}$ or more of the dry solvents through a good fractionating column. Keep a record of the temperatures at which the solvent starts to come over and at which $1 \mathrm{ml}, 2 \mathrm{ml}$, etc., are collected. Use these data to construct a graph of temperature versus cumulative volume. This curve indicates the boiling point of components since, at these boiling points, the volume increases without a corresponding increase in temperature. If the graph is drawn as the distillation proceeds, the fractions can be chosen so that each component is represented by a fraction. Of course, there will also be fractions which are between the steps and are mixtures of components.

Collect sufficient fractions so that the change in constants from fraction to fraction can be evaluated. 
In addition to the preceding information, it is helpful to have as much data as possible on the original solvent. The following system will give much information which cannot be obtained from distillation:

Determine specific gravity, $Z$ value, and refractive index of the original solvent.

Add $20 \mathrm{ml}$ of the original solvent and $2.0 \mathrm{ml}$ of water to a $25-\mathrm{ml}$ graduate, and mix thoroughly. Read the amount of solvent which is soluble, and calculate \% solubility. Determine the constants (specific gravity, $Z$ value, and refractive index) of the supernatant (insoluble portion). Calculate the constants of the soluble portion as in the following example:

sp gr original - (\% insol) $x(\mathrm{sp} g r$ insol) $=(\%$ sol $) \times(\mathrm{sp} g r$ sol).

The solvents which are completely extracted by this procedure include acetone, metranol, ethanol, and both $n$ - and isopropyl alcohols. Any of these, except methanol, can be recovered from the water layer by saturating it with $\mathrm{NaOH}$. In difficult cases, the recovered solvent can be distilled from $\mathrm{NaOH}$, using semimicro methods. The distillate, in most cases, has constants very close to the constants of the pure component.

Besides the solvents which are infinitely soluble in water, some, like ethyl acetate, butyl alcohol, and methyl ethyl ketone, can be partially extracted with water. Place the portion which remained from the first water extraction in a $100-$ ml graduate. Dilute to $100 \mathrm{ml}$ with water, and $\mathrm{mix}$ thoroughly. Determine the solubility, and convert it to $\%$ solubility in terms of the original composition, as follows:

$(\%$ sol $) \times(\%$ insol) on 1 st extraction $=\%$ sol in terms of criainal.

Using the constants of the supernatant, calculate the constants for the soluble portion. If desired, separate the water layer and saturate with $\mathrm{NaCl}$ to salt out the soluble solvent. Dry the recovered solvent over anhydrous $\mathrm{Na}_{2} \mathrm{SO}_{4}$ and determine the constants, or distill the material.

Remember that the recovered solvent is only part of that which is present. The remainder will be entirely soluble in $80 \% \mathrm{H}_{2} \mathrm{SO}_{4}$ or in an $80: 20$ mixture of $\mathrm{H}_{2} \mathrm{SO}_{4}$ and $\mathrm{H}_{3} \mathrm{PO}_{4}$.

Remove the supernatant from the water extraction, and place it in another graduate. Add an equal volume of $80 \% \mathrm{H}_{2} \mathrm{SO}_{4}$ or of an $80: 20 \mathrm{H}_{2} \mathrm{SO}_{4}: \mathrm{H}_{3} \mathrm{PO}_{4}$ mixture. (The latter causes less hydrolysis of esters, so that by diluting the acid layer to 3 or 4 volumes 
and saturating with $\mathrm{Na}_{2} \mathrm{SO}_{4}$, the esters can be recovered unchanged along with the other components, except unsaturated hydrocarbons.) Mix the acid and solvent thoroughly, and determine \% solubility. Convert this to \% solubility in terms of the original composition, as follows:

$(\%$ sol $) \times(\%$ water insol $)=\%$ solubility in terms of original.

Determine the constants of the supernatant (insoluble in $80 \%$ $\mathrm{H}_{2} \mathrm{SO}_{4}$ or in $\left.80: 22 \mathrm{H}_{2} \mathrm{SO}_{4}: \mathrm{H}_{3} \mathrm{PO}_{4}\right)$, and calculate the constants on the soluble portion.

If the solvent contains turpentine, the acid layer will be red. Esters produce an orange color, while alcohols and ketones usually give only a very light yellow. The presence of esters is also indicated by a higher calculated specific gravity than that of alcohols and ketones.

Recover the portion insoluble in $80 \% \mathrm{H}_{2} \mathrm{SO}_{4}$, place it in a graduate, and add twice the volume of fuming $\mathrm{H}_{2} \mathrm{SO}_{4}$ (30-33\% free $\left.\mathrm{SO}_{3}\right)$. Mix carefully and thoroughly. Determine the \% solubility, and calculate it in terms of $\%$ solubility of the original. Determine the constants on the portion which is insoluble in fuming $\mathrm{H}_{2} \mathrm{SO}_{4}$. (This must be pipetted by vacuum because of the fuming $\mathrm{H}_{2} \mathrm{SC}_{4}$.)

The soluble portion is an aromatic or halogenated aromatic hydrocarbon, and the remainder consists of aliphatic hydrocarbons or halogenated aliphatic hydrocarbons.

Use part of the original solvent or parts of the fractions from distillation to test for esters, ketones, alcohols, and halogenated hydrocarbons. (If steam distilled, the water layer will have to be checked for methanol.)

\section{TEST EOR MISCIBILITY}

Apparatus

Graduated cylinders, $25 \mathrm{ml}$, glass stoppered

Pipets, $10 \mathrm{ml}$, volumetric

\section{Reagents}

Hydrochloric acid, conc. (36\% $\mathrm{HCl})$

Sulfuric acid, $(80 \% \mathrm{v} / \mathrm{v})$

Dimethyl sulfate (CAUTION: Keep off the skin.) 


\section{Analytical Procedure}

1. Pipet a 10-ml sample into a dry, tared, graduated cylinder. Weigh and calculate the specific gravity.

2. Add $10 \mathrm{ml}$ of water, and mix gently.

a. Complete miscibility excludes:

(1) Saturated aliphatic hydrocarbons

(2) Aromatic hydrocarbons

(3) Halogenated saturated aliphatic or aromatic hydrocarbons

(4) Organic acids

(5) Weakly acidic compounds, such as:
(a) Phenols
(b) Enols
(c) Primary and secondary nitro compound's
(d) Oximes
(e) Amino acids

(6) Neutral compounds

3. Add $10 \mathrm{ml}$ of solvent to $10 \mathrm{ml}$ of conc. $\mathrm{HCl}$ (or $80 \%$ $\mathrm{H}_{2} \mathrm{SO}_{4}$ ); mix gently by inverting several times. Let settle, and note the volumes.

a. Complete miscibility includes:
(1) Alcohols
(2) Esters
(3) Aldehydes
(4) Ketones
(5) Unsaturated compounds
(6) Anhydrides
(7) Ethers
(8) Quinones

b. Complete insolubility includes:

(1) Saturated aliphatic and aromatic hydrocarbons

(2) Halogenated saturated aliphatic and aromatic hydrocarbons 
4. Cautiously add a 10-ml sample to $10 \mathrm{ml}$ of dimethyl sulfate in a graduated cylinder. Stopper and invert several times to miy. (Watch for pressure when relieving the stoper.)

NOTE: Solubility is an index to the aromatic content. If, however, the solubility exceeds $25 \%$, dilute the sample accurately with heptane, benzene, or petroleum ether; and repeat the procedure.

Calculations Eor Miscibility

$\%$ miscibility $=\frac{(\text { vol orig - vol final })}{\text { vol orig }} \times 100$

I I. BEILSTEIN TEST EOR HALOGENATED HYDROCARBONS

\section{Analytical Procedure}

1. Prepare a small copper wire, supported in a glass tubing handle, with a small loop at the end.

2. Heat the wire until only a yellow flame exists. To avoid melting the wire, use the edge of the flame.

3. Cool the wire loop. Dip it into the sample.

4. Heat the sample in the edge of the flame. A green color indicates a halogen.

II I. DETERMINATION OE AROMATIC CONTENT BY REERACTJVE INDEX AND DISPERSION MEASUREMENT

\section{Apparatus}

Refractometer. Abbe type

Graph paper, rectangular

\section{Reagents}

Benzene, pure

Isooctane $(2,2,4$-trimethylpentane), pure

Standards, $20 \%, 40 \%, 60 \%$, and $80 \%$ mixtures (by volume) of benzene in isooctane 


\section{Analytical Procedure}

1. Using the refractometer, determine the index of refraction and dispersion values for the standards and the unknown sample.

2. Plot index versus \% aromatic for the standards.

3. Determine the specific dispersion, using the refractometer nomograph and the density of the samples.

4. Plot specific dispersion.

5. Compute the aromatic composition of the unknown, using the two graphs.

\section{DETERMINATION OF METHYL KETONES}

\section{Apparatus}

spot plate, white

\section{Reagents}

Sample sclvent

Acetone

Sodium nitroprusside (5\%)

Sodium hydroxide $(30 \%)$

Acetic acid, glacial

Analytical Procedur.'

1. Into separate spot-plate depressions, place 1 drop of aqueous or alcoholic sample and 1 drop of acetone, for comparison. Add 1 drop of $5 \%$ sodium nitroprusside and 1 drop of $30 \% \mathrm{NaOH}$.

2. After a short time, add 1 or 2 drops of acetic acid.

3. A purple color indicates the presence of a methyl ketone. 


\section{DETERMINATION OF ESTERS}

\section{Apparatus}

Crucible, porcelain, 20-ml volume

Micro burner + porcelain triangle

Ring stand for triangle support

\section{Reagents}

Hydroxylamine, saturated alcoholic solution

Potassium hydroxide, saturated alcoholic solution

Hydrochloric acid $(0.5 \mathrm{~N})$ - Dilute $4.1 \mathrm{ml}$ of conc. HCl to $100 \mathrm{ml}$.

Ferric chloride solution (1\%) - Dissolve $1 \mathrm{~g}$ of $\mathrm{FeCl}_{3}$ in $100 \mathrm{ml}$ of water.

Amyl acetate

\section{Analytical Procedure}

1. To 1 drop of dry unknown in a crucible, add 1 drop of $\mathrm{NH}_{2} \mathrm{OH} \bullet \mathrm{HCl}$ and 1 drop of $\mathrm{KOH}$. Heat until bubbling begins.

2. Cool, and add 1 drop of $\mathrm{HCl}$ and 1 drop of $\mathrm{FeCl}_{3}$.

3. An intense violet color indicates the presence of an ester.

4. To 1 drop of amyl acetate, add 1 drop of $\mathrm{NH}_{2} \mathrm{OH} \bullet \mathrm{HCl}$ and 1 drop of $\mathrm{KOH}$. Heat, and then cool and add 1 drop of $\mathrm{HCl}$ and 1 drop of $\mathrm{FeCl}_{3}$. Note the color for comparison with the sample.

VI. DETERMINATION OE ALCOHOLS (CERATE TEST)

\section{Reagents}

Ceric nitrate reagent - Dissolve $90 \mathrm{~g}$ of ceric ammonium nitrate in $225 \mathrm{ml}$ of warm $2 \mathrm{~N} \mathrm{HNO}_{3}$. 


\section{Analytical Procedure}

1. Add $0.5 \mathrm{ml}$ of ceric nitrate reagent to $2 \mathrm{ml}$ of an aqueous solution of the unknown in a test tube. Shake.

2. In the presence of alcohols, glycols, hydroxy acids, hydroxy esters, and hydroxy aldehydes and ketones that contain no more than 10 carbon atoms, the solution changes from a bright yellow to amber, yellow-orange, or red. (Note that phenols produce a green-brown or brown precipitate.)

\section{DETERMINATION OE METHANOL}

\section{Apparatus}

Spectrophotometer, Hewlett-Packard Model $8450 \mathrm{~A}$

Graduated cylinders, glass-stoppered, 25 or $100 \mathrm{ml}$

Pipets

\section{Reagents}

\section{Ethanol}

Potassium permanganate reagent - Dissolve $3 \mathrm{~g}$ of $\mathrm{KMnO}_{4}$ in $15 \mathrm{ml}$ of $85 \% \mathrm{H}_{3} \mathrm{PO}_{4}$, and combine with $85 \mathrm{ml}$ of distilled water.

Oxalic acid reagent - Dissolve $5 \mathrm{~g}$ of oxalic acid in $100 \mathrm{ml}$ of $1: 1 \mathrm{H}_{2} \mathrm{SO}_{4}$.

Schiff's reagent, modified - Add $0.2 \mathrm{~g}$ of fuchsin to $120 \mathrm{ml}$ of hot water, cool, and add a solution of $2 \mathrm{~g}$ of anhydrous sodium bisulfite in $20 \mathrm{ml}$ of water. Mix thoroughly. Add $2 \mathrm{ml}$ of conc. $\mathrm{HCl}$, and dilute to 200 ml with water. Store in a well-stoppered brown bottle in the refrigerator. If any residual color remains in the reagent, remove it by passing a stream of $\mathrm{SO}_{2}$ through the reagent.

Standard methanol solution ( $5 \mathrm{mg}$ methanol/ml) - Dilute $1 \mathrm{ml}$ of methanol to $200 \mathrm{ml}$ with distilled water.

\section{Analytical Procedure}

1. Add $0.25 \mathrm{ml}$ of ethanol to $5 \mathrm{ml}$ of aqueous unknown in a 25-ml graduated cylinder; $\mathrm{mix}$ and add $2 \mathrm{ml}$ of $\mathrm{KMnO}_{4}$ reagent. 
2. Allow to set for 10 minutes.

3. Decolorize the solution with $2 \mathrm{ml}$ of oxalic acid reagent.

4. Add $5 \mathrm{ml}$ of Schiff's reagent, mix, and allow to set for one hour. Read the absorbance at $570 \mathrm{~nm}$.

5. Compare with standard methanol (1-2.5 mg), treated the same way and at the same time.

6. A violet color indicates methanol.

7. If the color is too intense, dilute the entire sample to $100 \mathrm{ml}$ with water; and read again.

\section{MISCELLANEOUS TECHNIQUES}

Instrumental analytical techniques have become extremeiy helpful in product identification. The following table indicates a possible approach:

\begin{tabular}{|l|l|}
\hline \multicolumn{1}{|c|}{ TYPE } & \multicolumn{1}{|c|}{ METHODS TO BE TRIED } \\
\hline Organic liquid & $\begin{array}{l}\text { Gas chromatography, infrared analysis of } \\
\text { GC fractions, fractional distillation, } \\
\text { density, refractive index, infrared } \\
\text { analysis of fractions }\end{array}$ \\
\hline Organic solid & $\begin{array}{l}\text { KBr pellet infrared, soxhlet extraction, } \\
\text { organic qualitative scheme, inorganic } \\
\text { cations \& anions }\end{array}$ \\
\hline $\begin{array}{l}\text { Inorganic liquid (Water } \\
\text { solution) \& inorganic }\end{array}$ & $\begin{array}{l}\text { Anion qualitative scheme, atomic } \\
\text { absorption, ICP }\end{array}$ \\
\hline $\begin{array}{l}\text { Glues, emulsions, soaps, } \\
\text { etc. }\end{array}$ & $\begin{array}{l}\text { Solvent extraction, gas chromatography, } \\
\text { infrared analysis, ASTM standard methods }\end{array}$ \\
\hline
\end{tabular}

After the analysis of a product, it is sometimes of great value to synthesize it on the basis of the determined constituents. For example, if a commercial paint solvent is found to consist of five components, each contributing $20 \%$ to the total mixture, a synthetic sample can be made for comparison of the infrared spectrum. Any previously undetected component or any variation in quantitative ratios will be evident immediately. 


\section{REEERENCES}

1. N.D. Cheronis, J.B. Entrikin, and E.M. Hodnett, Semimicro Qualitative Organic Analysis ( $3 \mathrm{rd}$ ed; New York: Interscience Publishers, Inc., 1966).

2. F. Feigl, Spot Tests in Inorganic Analysis, translated by R.E. Oesper (5th English ed; New York: Elsevier Publishing Co., 1958).

3. F. Feigl, spot Tests in organic Analysis, translated by R.E. Oesper ( 6 th English ed; New York: Elsevier Publishing Co., 1960).

4. Lange's Handbook of Chemistry, ed J.A. Dean (11th ed; New York: McGraw-Hill Book Co., 1973).

5. Handbook of Chemistry and Physics (67th ed; Cleveland, $\mathrm{OH}$ : Chemical Rubber Publishing Co., 1987).

6. R.T. Conley, Infrared Spectroscopy (Boston: Allyn and Bacon, Inc., 1966).

7. L.J. Bellamy, The Infra-red Spectra of Complex Molecules ( 2 nd ed; New York: John Wiley \& Sons, Inc., 1958).

Reviewed by:

Reviewed by:

Reviewed by:

Reviewed by:

Reviewed by:
Review date:

Review date:

Review date:

Review date:

Review date: 


\section{ABSTRACT}

This method describes the Pensky-Martens closed flash tester, as used in ASTM Method D93-62, "Test for Flash Point by PenskyMartens Closed Tester."

\section{APPLICATIONS AND LIMITATIONS}

Elash-point determination measures the tendency of a sample to form a flammable mixture with air. It can also indicate the possible presence of volatile contaminants in a relatively nonvolatile material. The procedure is used on fuel oils, as well as viscous materials and suspensions of solids, but is not applicable to drying oils, solvent-type liquid waxes, or cutback asphalts. (Use ASTM D-1310.)

\section{ES\&H NOTES}

Keep the flash point tester well shielded and apply the flame cautiously to avoid causing an external fire.

\section{APPARATUS}

Pensky-Martens tester, ASTM Specification E-134

Thermometers, range $20-230^{\circ} \mathrm{F}$ and $200-700^{\circ} \mathrm{F}$

\section{ANALYTICAL PROCEDURE}

1. Eill the cup with the material to be tested to the level indicated by the filling mark. Place the lid on the cup, set the cup on the stove, and lock it into position.

2. Insert the thermometers, and light the test flame.

3. Turn on the stirrer, and apply heat at such a rate that the temperature, as read on the thermometer, increases $9-11^{\circ} \mathrm{F}$ per minute.

4. Apply the test flame by operating the mechanism on the cover which controls the shutter; and test the flame burner so that the flame is lowered into the vapor space of the cup in 0.5 seconds, left in its lowered position for 1 second, and quickly raised to its high position. 
5. The flash point is the temperature read on the thermometer at the time the test flame application causes a distinct $f l a s h$ in the interior of the cup. Sometimes the test flame during application is surrounded with a bluish halo as the flash-point temperature is approached. Do not confuse the true flash with this halo.

\section{CALCULATIONS}

Observe and record the barometric pressure. For each $25 \mathrm{~mm}$ below the $760-\mathrm{mm}$ barometric reading, add $1.5^{\circ} \mathrm{F}$ to the flash point. For each $25 \mathrm{~mm}$ above $760 \mathrm{~mm}$, subtract $1.5^{\circ} \mathrm{F}$ from the flash point.

\section{REFERENCES}

1. "Standard Test Methods for Elash Point by Pensky-Martens Closed Tester," ASTM Standard D 93-85 in Vo1. 6.03 Paints, Related Coatings, and Aromatics (Philadelphia: American Society for Testing and Materials, 1987).

Reviewed by:

Reviewed by:

Reviewed by:

Reviewed by:

Reviewed by:
Review date:

Review date:

Review date:

Review date:

Review date: 


\section{ABSTRACT}

Formaldehyde reacts with a chromotropic acid-sulfuric acid solution to form a stable, purple-colored complex, which can be measured colorimetrically at $580 \mathrm{~nm}$.

\section{APPLICATIONS AND LIMITATIONS}

The analytical range for an 80-liter air sample is 0.02 to 0.4 PPM. For greater accuracy, the formaldehyde standard solution should be standardized (see Reference 1).

Phenols interfere, but little interference is seen from other aldehydes. Alcohols, olefins, and aromatic hydrocarbons produce very small interferences.

\section{ES\&H NOTES}

Formaldehyde is designated as a Class A2 carcinogen by the ACGIH and a Class $2 \mathrm{~A}$ carcinogen by the IARC. This material should be handled in a Designated Area, typically a laboratory hood. The room and/or hood shall be clearly labeled with a sign indicating that a carcinogen is in use.

\section{APPARATUS}

Spectrophotometer, Hewlett-Packard Model $8450 \mathrm{~A}$

Midget bubblers, all glass

Assorted laboratory glassware

\section{REAGENTS}

Sodium bisulfite (1\%) - Dissolve $1 \mathrm{~g}$ of $\mathrm{NaHSO}_{3}$ in $100 \mathrm{ml}$ of distilled water. PREPARE FRESH WEEKLY.

Chromotropic acid (1\%) - Dilute $0.10 \mathrm{~g}$ of 4,5-dihydroxy-2,7naphthalene disulfonic acid disodium salt to $10 \mathrm{ml}$ with water. Filter and store in a brown bottle. PREPARE FRESH WEEKLY.

Sulfuric acid, conc. $\left(96 \% \mathrm{H}_{2} \mathrm{SO}_{4}\right)$

Aldehyde-free water - Boiled, doubly-distilled water 
Eormalin solution, $37 \%$ formaldehyde $(37 \mathrm{~g} \mathrm{HCHO} / 100 \mathrm{ml}$ of solution)

Eormaldehyde stock solution ( $1 \mathrm{mg} \mathrm{HCHO} / \mathrm{ml})$ - Dilute $2.7 \mathrm{ml}$ of formalin solution to $1000 \mathrm{ml}$ with distilled water.

Formaldehyde standard solution $(10 \mu \mathrm{g} / \mathrm{ml})$ - Dilute $1 \mathrm{ml}$ of formaldehyde stock solution to $100 \mathrm{ml}$ with $1 \%$ sodium bisulfite. PREPARE FRESH WEEKLY.

\section{ANALYTICAL PROCEDURE}

1. Collect the sample in a midget bubbler, using $15 \mathrm{ml}$ of a $1 \%$ sodium bisulfite solution as a collecting medium. Collect at least $100 \mathrm{~L}$ of air. Note the volume of each impinger.

2. Pipet 4-ml aliquots from each sample solution into 40-ml centrifuge tubes.

3. Add $0.1 \mathrm{ml}$ of $1 \%$ chromotropic acid to the tubes and $\mathrm{mix}$.

4. Slowly add $6 \mathrm{ml}$ of conc. $\mathrm{H}_{2} \mathrm{SO}_{4}$ to the tubes. Let the color develop for 30 minutes, while the tubes cool to room temperature. Transfer the solution to absorbance cells, and read the absorbance at $580 \mathrm{~nm}$. If the absorbance is too high, dilute a smaller aliquot to $4 \mathrm{ml}$ with $1 \%$ sodium bisulfite and analyze.

5. Prepare a series of standards containing from 1 to $20 \mu \mathrm{g}$ of formaldehyde ( 0.1 to $2.0 \mathrm{ml}$ of standard solution) in enough $1 \%$ sodium bisulfite to yield $4 \mathrm{ml}$ of solution. Proceed as in step 2 .

6. Plot absorbance versus concentration in $\mu \mathrm{g}$ of formaldehyde/4 $\mathrm{ml}$.

7. Determine the amount of formaldehyde present in the samples from the standard curve.

\section{CALCULATIONS}

$\mathrm{mg}$ formaldehyde $/ \mathrm{m}^{3}=\mu \mathrm{g}$ formaldehyde from calibration curve Vol of air sampled in liters at STP 


\section{REEERENCES}

1. "Formaldehyde," NIOSH Manual of Analytical Methods, Vol. 1, U.S. Department of Health and Human Services Publication No. 84-100, ed P.M. Eller (3rd ed; Washington, DC: U.S. Government Printing office, 1984), Method 3500.

2. "Tentative Method of Analysis for Formaldehyde Content of the Atmosphere (Colorimetric Method)," Methods of Air Sampling and Analysis, ed M. Katz (2nd ed; Washington, DC: American Public Health Association, 1977), Method 116.

Reviewed by:

Reviewed by:

Reviewed by:

Reviewed by:

Reviewed by:
Review date:

Review date:

Review date:

Review date:

Review date: 
THIS PAGE INTENTIONALLY LEFT BLANK

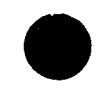




\section{ABSTRACT}

Air samples are collected on Whatman No. 41 filter paper, 37-mm membrane filters, or electrostatic precipitators (ESP); or by suitable organic solvents. The oil mist is extracted or washed into an organic solvent and quantitated using either Fourier transform infrared or ultraviolet spectrophotometry.

\section{APPLICATIONS AND LIMITATIONS}

The working range for this technique, using infrared spectrophotometry, is 0.1 to $2.5 \mathrm{mg}$ per sample, assuming a sampling flow rate of 1-2 liters/minute.

\section{APPARATUS}

Fourier transform infrared spectrometer, Bio-Rad Model ETS-7 with $\mathrm{NaCl}$ cells

U1traviolet spectrophotometer, Hewlett-Packard Model 8450A, with silica cells

Cellulose membrane filters, $37 \mathrm{~mm}$ ( $0.8 \mathrm{micron})$

ESP collection kit

Whatman No. 41 filter paper, $47 \mathrm{~mm}$

Assorted laboratory glassware

\section{REAGENTS}

Solvents, such as ether, carbon tetrachloride, isooctane, chloroform, trichlorotrifluoroethane, etc.

Oil standard $(100 \mathrm{mg} / \mathrm{ml})$ - Weigh $10 \mathrm{~g}$ of the oil being sampled into $100 \mathrm{ml}$ of a suitable solvent.

\section{ANALYTICAL PROCEDURE}

1. Prepare 1 - to $100-\mu \mathrm{g} / \mathrm{ml}$ standards of the oil in question in a suitable solvent.

2. Transfer the collected samples into scintillation vials, and extract the oil using $20 \mathrm{ml}$ of the same solvent used to prepare the standards. 
3. Record the spectra at the particular wavelength at which the oil has maximum absorbance.

4. Measure the Desorption Efficiency (DE) for each oil at least once for each lot of filters. Deposit a known amount of oil onto a filter; evaporate the solvent and allow to stand overnight; desorb and analyze as in Steps 1-3. The desorption efficiency is the ratio between the amount of analyte recovered and the amount deposited (see Reference $1)$.

5. Quantitatively determine the amount of oil, using the standards for that oil, by plotting the peak height versus concentration in $\mu \mathrm{g} / \mathrm{ml}$.

\section{CALCULATIONS}

$\mathrm{mg}$ oil $/ \mathrm{m}^{3}=\frac{\mu \mathrm{g} \text { oil trom curve } / D E}{\text { liters of air sampled }} \times$ dilution factor (if any)

\section{REEERENCES}

1. "Mineral Oil Mist," NIOSH Manual of Analytical Methods, Vol. 1 , U.S. Department of Health and Human Services Publication No. 84-100, ed P.M. Eller (3rd ed, Suppl 2; Washington, DC: U.S. Government Printing Office, 1987), Method 5026.

2. E.M. Ray, "Sampling and Determination by Ultraviolet Absorption of Oil Mists and Solvent Vapors," Am Ind Hyg Assoc J $31: 472$ (1970).

3. M. Lippman and D.H Goldstein, "Oil-Mist studies, Environmental Evaluation and Control," Arch Environ Health 21:591 (1970).

Reviewed by:

Reviewed by:

Reviewed by:

Reviewed by:

Reviewed by:
Review date:

Review date:

Review date:

Review date:

Review date: 


\title{
ORGANIC SOLVENTS IN AIR
}

\begin{abstract}
A known volume of air is drawn through a sorption tube or a $3 \mathrm{M}$ Company Organic Vapor Badge to trap the organic vapors present. The sorbant is cransferred to a graduated cylinder and desorbed with carbon disulfide. An aliquot is injected into a gas chromatograph, and the area of the resulting peak is determined and compared with areas obtained from the injection of standards.
\end{abstract}

\section{APPLICATIONS AND LIMITATIONS}

The sampling device is small and portable and involves no liquids. The $3 \mathrm{M}$ Vapor Badges are easier to use, since there is no need to calibrate a sampling pump. However, since they are passive devices, sampling times are generally longer than those required for the sorption tubes.

Interferences are minimal, and most of those which do occur can be eliminated by altering the chromatographic conditions. Precision of the analytical method is $\pm 7 \%$.

A disadvantage of the method is that the amount of sample which can be absorbed is limited by the number of milligrams that the sorbant in the tube or badge will hold before overloading. When the amount of water in the air is so great that condensation occurs, organic vapors will not be trapped. When two or more solvents are known or suspected to be present in the air, such information, including their suspected identities, should be transmitted with the sample since, with differences in polarity, one may displace another from the sorbant.

It must be emphasized that any compound having the same retention time as the specific compound under study at the operating conditions described in this method is an interference. Hence, retention-time data on a single column, or even on a number of columns, cannot be considered as proof of chemical identity. For this reason, it is important that a sample of the bulk solvent(s) be submitted at the same time so that identities can be established by other means.

\section{ES\&H NOTES}

A number of organic solvents are designated as carcinogens, suspect carcinogens, or reproductive hazards. These materials should be handled in a Designated Area, typically a laboratory hood. The room and/or hood shall be clearly labeled with a sign indicating that a carcinogen or particularly hazardous material is in use. 
In addition, many organic solvents are highly flammable. Carbon disulfide, the preferred desorbant for this procedure is both highly flammable and acutely hazardous.

\section{APPARATUS}

3M Organic Vapor Badges \#3500 - Model 3500 badges are nonspecific, absorbing several organic vapors simultaneously (see Reference 1).

Charcoal tubes - Glass tube with both ends flame sealed, containing two sections of a sorbent material (i.e., activated charcoal, sij.ica gel, Chromosorb, etc.) separated by a 2-mm portion of urethane foam. A 3-mm portion of urethane foam is placed between the outlet end of the tube and the backup section. A plug of glass wool is placed in front of the absorbing section. Most of the tubes used are non-specific, absorbing several organic vapors simultaneously.

Gas chromatograph, Hewlett-Packard Model 5880A, equipped with a flame ionization detector

Column ( 20 ft $\times 1 / 8$ in) with GP $10 \%$ SP-1000 stationary phase on $80 / 100$ mesh Supelcoport solid support (Supelco, Inc.)

Disposable glassware, such as $20 \mathrm{ml}$ glass vials, for standards and sample preparation

Hamilton syringes, $10 \mu 1$

Pipets or repipetors of appropriate volumes

Recorder and some method for determining peak area

\section{REAGENTS}

Carbon disulfide, Spectrograde

Methylene chloride

Nitrogen, purified

Hydrogen, prepurified

Compressed air, filtered

Bulk sample of the compound under study 
ANALYTICAL PROCEDURE

1. Preparation of the samples:

Sorbent tubes: Remove and discard the glass wool in front of the first section of sorbent. Transfer the sorbent in the first (larger) section to a disposable glass container with a lid. Remove and discard the separating section of foam, and transfer the second section to another container. Alternatively, combine both sections in.the same container.

Add a known volume (usually $5 \mathrm{ml}$ ) of $\mathrm{CS}_{2}$ or methylene chloride to each container. Maximum desorption occurs in about 30 minutes when the sample is occasionally gently agitated; if the sample is not agitated, complete desorption requires 3 hours.

3M Vapor Badges: Open the badge, and transfer the sorbent material to a glass container. Add a known volume (usually $5 \mathrm{ml}$ ) of an appropriate solvent, usually $\mathrm{CS}_{2}$ or methylene chloride (see Reference 1). Maximum desorption occurs in about 30 minutes when the sample is occasionally gently agitated. Alternatively, inject the solvent directly into the badge, and allow to desorb for 30 minutes. Withdraw an aliquot from the badge for injection.

2. GC conditions: The typical operating conditions for the gas chromatograph are:
a. Nitrogen gas flow: $85 \mathrm{cc} / \mathrm{min}$ ( $70 \mathrm{psig}$ )
b. Hydrogen gas flow to detector: $65 \mathrm{cc} / \mathrm{min}$ ( $24 \mathrm{psig}$ )
c. Air flow to detector: $500 \mathrm{cc} / \mathrm{min}$ ( $50 \mathrm{psig}$ )
d. Injector temperature: $200^{\circ} \mathrm{C}$
e. Manifold detector temperature: $250^{\circ} \mathrm{C}$

f. Isothermal oven or column temperature: Refer to Table C-1 for specific compounds. For compounds not found in the Table, see Reference 2 or 3.

3. Injection: The first step in the analysis is the injection of the sample into the GC. To eliminate difficulties arising from blowback or distillation within the syringe needle, use the solvent flush injection technique. First flush the 10-4l syringe with solvent several times to wet the barrel and plunger. Immerse the needle in the sample and withdraw a known (usually 4- 41 ) aliquot. After removing the needle from the sample prior to injection, pull back the plunger a short distance to minimize evaporation of the 
sample from the tip of the needle. Run duplicate injections of each sample and standard. No more than a $3 \%$ difference

in area is to be expected.

4. Area measurement: Measure the area of the sample peak using an electronic integrator or some other suitable form of area measurement. Read the preliminary results from a standard curve prepared as discussed below.

5. Measurement of Desorption Efficiency (DE): Measure the desorption efficiency for each compound at least once for each lot of tubes or monitors. Inject a known amount of analyte into a tube or monitor, allow to stand overnight, desorb, and analyze. The desorption efficiency is the ratio between the amount of analyte recovered and the amount injected. (See Reference 2 for details.)

6. Standard calibration: It is convenient to express the concentration of the standards in terms of $\mathrm{mg}$ per known volume of desorbant used. Use the density of the specific compound to convert $\mathrm{mg}$ to microliters for easy measurement with a microliter syringe. The use of a single standard is sufficient if the standard curve is known to be linear in the range of interest. If the curve is nonlinear, or linearity has not been determined, prepare and analyze a series of standards, varying in concentration over the range of interest, under the same GC conditions and during the same time period as the unknown samples. Plot concentration in $\mathrm{mg} \mathrm{CS}_{2}$ versus peak area.

NOTE: Since no internal standard is used in this method, analyze standard solutions at the same time that the sample analysis is done. This will minimize the effect of day-today variations of the FID response.

\section{CALCULATIONS}

1. If not using a standard curve, calculate a Response Factor for each compound analyzed, as follows:

$$
\begin{array}{r}
\text { Response factor }(R E)=\mu l \text { standard added } x \text { density } \\
\text { peak area for standard }
\end{array}
$$

Then, $m g$ of sample, $\mathrm{mg}_{\mathrm{n}}=R E \times$ peak area for sample.

2. If using a standard curve, read the weight in mg corresponding to each peak area from the curve for the compound of interest. No volume corrections are needed, because the volumes of samples and standards injected are identical. 
3. For either procedure, correct each sample for the desorption efficiency and the blank, as follows:

$$
\begin{array}{ll}
\mathrm{DE}-\text { corrected } \mathrm{mg}(\mathrm{DE}) & =\mathrm{mg}_{\mathrm{a}} / \mathrm{DE} \\
\mathrm{Blank} \text {-corrected } \mathrm{mg} & =\mathrm{mg}(\mathrm{DE})-\mathrm{mg}_{\mathrm{b}}
\end{array}
$$

where

$$
\begin{aligned}
& m g_{n}=m g \text { found in the sample tube } \\
& \mathrm{mg}_{\mathrm{b}}=\mathrm{mg} \text { found in the blank tube. }
\end{aligned}
$$

If running the two sorbent sections separately, add the corrected amounts present in the front and backup sections of the same sample tube to determine the total measured amount in the sample.

4. For sorbent tubes, calculate the concentration in air, as follows:

$$
\mathrm{mg} / \mathrm{m}^{3}=\mu \mathrm{g} / \mathrm{L}=\frac{\text { total } \mathrm{mg} \times 1000}{\text { vol of air in liters at STF }}
$$

5. Calculation of contaminant concentrations for $3 \mathrm{M}$ organic Vapor Badges requires the incorporation of a "calculation constant," which can be found in Reference 1.

\section{REEERENCES}

1. 3M Organic Vapor Monitor \#3500 Compound Guide Notebook (St. Paul, MN: 3M Occupational Health and Safety Products Division, 1982).

2. "Organic Solvents in Air," NIOSH Manual of Analytical Methods, Part I, U.S. Department of Health, Education, and Welfare Publication No. 77-157-A, ed D.G.Taylor (2nd ed; Washington, DC: U.S. Government Printing Office, 1977), Method 127.

3. "Hydrocarbons, Halogenated," NIOSH Manual of Analytical Methods, Vol. 1, U.S. Department of Health and Human Services Fublication No. 84-100, ed P.M. Eller (3rd ed, Suppl 2; Washington, DC: U.S. Government Printing Office, 1987), Method 1003.

4. "Hydrocarbons, Aromatic," NIOSH Manual of Analytical Methods, Vol. 1, U.S. Department of Health and Human Services Publication No. 84-100, ed P.M. Eller (3rd ed; Washington, DC: U.S. Government Printing Office, 1984), Method 1501. 
5. "Dioxane," NIOSH Manual of Analytical Methods, Vol. 1, U.S. Department of Health and Human Services Publication No. 84100, ed P.M. Eller (3rd ed, Suppl 1; Washington, DC: U.S. Government Printing Office, 1985), Method 1602.

6. L.D. White et al., "A Convenient Optimized Method for the Analysis of Selected Solvent Vapors in the Industrial

Atmosphere," Amer Ind Hyg Assoc J 31:225 (1970).

Reviewed by:

Reviewed by:

Reviewed by:

Reviewed by:

Reviewed by:
Review date:

Review date:

Review date:

Review date:

Review date: 


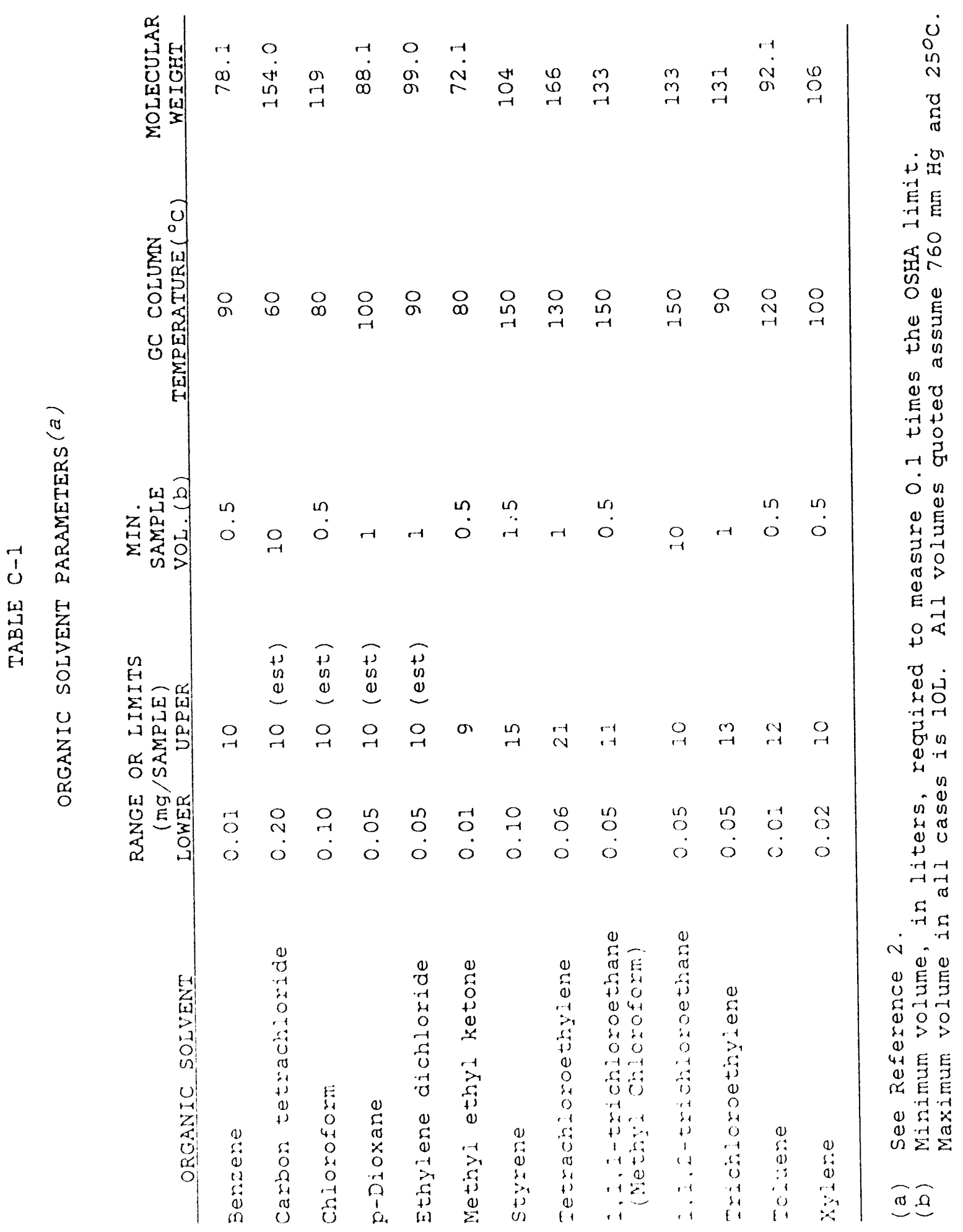


THIS PAGE INTENTIONALLY LEFT BLANK 


\section{ABSTRACT}

The presence of polychlorinated biphenyls ( $\mathrm{PCB}^{\prime} \mathrm{s}$ ) in waste oil streams must be determined in order to select the proper method of cleanup or disposal. The analytical technique used in the Industrial Hygiene Chemistry Lab emphasizes screening of samples, using Fourier transform infrared spectroscopy (ETIR) for gross screening and gas chromatography (GC) for verification and semiquantitation.

\section{APPLICATIONS AND LIMITATIONS}

The FTIR is used to screen samples for PCB's in the thousand PPM range. If no $\mathrm{PCB}^{\prime} \mathrm{s}$ are indicated by this technique, the samples are extracted in hexane and run on the GC. Depending upon the sample quality and size, the detection limit for the GC is 5-10 PPM.

The technique is limited by several factors: (1) The chromatographic column can be overloaded fairly easily, causing several hours to days delay while it is cleaned up. This problem is the reason for pre-screening the samples using the IR. (2) Samples may contain degraded PCB's (having non-standard peak patterns) or solvents and/or water as contaminents (making them difficult to clean up); both problems can obscure the identification of the $\mathrm{PCB}$ peaks. (3) Sample runs on the IR take about 15 minutes; those on the GC, about 45 minutes, limiting the number of samples that can be run in a day. (4) Finally, this technique, as practiced in our laboratory, does not meet $\mathrm{EPA}$ requirements for the quantitation of $\mathrm{PCB}^{\prime} \mathrm{s}$.

\section{ES\&H NOTES}

Polychlorinated biphenyls are designated as Class $2 \mathrm{~A}$ carcinogens by the IARC. These materials should be handled in a Designated Area, typically a laboratory hood. The room and/or hood shall be clearly labeled with a sign indicating that a carcinogen is in use.

\section{APPARATUS}

Gas Chromatograph, Hewlett-Packard Model 5880A with Electron Capture Detector and Integrator

Eourier transform infrared spectrophotometer, Bio-Rad Model ETS -7 
Balance, Mettler Model AE163, weighing to $0.1 \mathrm{mg}$

Pipettes, disposable

Salt plates for the ETIR, sodium chloride or potassium bromide

Scintillation vials

Syringes, $10 \mu \mathrm{l}$, liquid

\section{REAGENTS}

Hexane, Pesticide grade

Arochlor standards, most commonly those designated 1242 , 1254 , and 1260

\section{ANALYTICAL PROCEDURE}

\section{Infrared spectroscopy}

1. Place a drop of oil on a salt plate. If the sample consists of more than one layer, sample only the top layer.

2. Assemble the sample cell, place it in the sample compartment, and scan the FTIR spectrum. The run will take less than 1 minute.

3. The major characteristic peaks for $\mathrm{PCB}^{\prime} \mathbf{s}$ occur at 755, 780, $810,880,1028,1095,1135$, and $1750 \mathrm{~cm}^{-1}$.

4. If no $\mathrm{PCB}^{\prime}$ s are detected, the oil samples must be extracted with hexane and run on the gas chromatograph.

\section{Sample preparation}

1. Weigh and tare a scintillation vial.

2. Pipette approximately $0.1 \mathrm{~g}$ of oil into the vial, and record the weight.

3. Add exactly $10 \mathrm{ml}$ of hexane and extract for 2-3 hours, agitating occasionally. The sample is now ready for gas chromatographic analysis. 
Gas Chromatography

1. GC conditions: Operating conditions for the GC are as follows:

a. Column: $6 \mathrm{ft} \times 4 \mathrm{~mm}$ packed glass containing Supelco $1.5 \% \mathrm{SP}-2250 / 1.95 \% \mathrm{SP}-2401$ on $100 / 120$ mesh Supelcoport

b. Detector: Electron capture

c. Nitrogen gas flow: The flow should be such that the hexane peak elutes at an approximate relative retention time of $0.5 \mathrm{sec}$ at $42 \mathrm{psig}(\sim 90-100 \mathrm{cc} / \mathrm{min})$.

d. Oven temperature: $200^{\circ} \mathrm{C}$

e. Detector temperature: $300^{\circ} \mathrm{C}$

f. Injector temperature: $250^{\circ} \mathrm{C}$

\section{Analysis}

a. Turn on the Nitrogen gas flow, then the gas chromatograph. From the PCB Program Tape, get ANALYSIS "REVMXPCB2/83". This program contains the operating conditions for the instrument and the calibration factors for the PCB peaks. Allow the instrument to warm up until a stable baseline is achieved (15-20 minutes).

b. Get PRGM "GRAYREVMXPCB2/83", which starts the analysis and prints out the analytical results. Remove the Program Tape, and insert the PCB Data Tape. All chromatographic information is stored on the tape and is available for later manipulation.

c. Rinse a 10-4l glass syringe 5-10 times with the sample to be analyzed. Draw up $1.8 \mu 1$ of sample, then draw back the plunger until air enters the barrel. This will minimize evaporation of the sample from the needle during injection.

d. Be sure the autosampler is in position 1. After answering the appropriate questions for the data system, carefully inject the sample into injector $A$. The sample run will take about 45 minutes.

e. The analytical program prints out a chromatogram and, for each peak, the retention time, peak area, and percent of total area. 


\section{Quantitation}

a. After determining from the initial chromatogram that PCB's are probably present, another sample must be run for quantitative analysis. The sample may be either diluted further or made up as a more concentrated hexane solution (a larger amount of oil in the $10 \mathrm{ml}$ of hexane). It may be necessary to clean up the sample using a Fluorosil column before quantitation (see Reference 3 ).

b. Proceed as in the Analysis Section, injecting $2.8 \mu 1$ of sample into the GC. All calculations are based upon a $2.8-\mu 1$ injection and $10 \mathrm{ml}$ of hexane.

c. The quantitative report identifies the predicted $P C B$ and peak number and the nanograms represented by each peak. The program then calculates total PPM of PCB's by weight.

d. In addition, to assure that the computer program has correctly interpreted the data, compare the chromatogram with those of individual Arochlor standards. The peak patterns must match in order to successfully identify a given $\mathrm{PCB}$.

e. Occasionally run known Arochlor standards to check the calculations.

\section{REFERENCES}

1. "Polychlorobiphenyls," NIOSH Manual of Analytical Methods, Vol. 1, U.S. Department of Health and Human Services Publication No. 84-100, ed P.M. Eller (3rd ed, Suppl 2; Washington, DC: U.S. Government Printing Office, 1987), Method 5503 .

2. "Standard Method for Analysis of Polychlorinated Biphenyls in Insulating Liquids by Gas Chromatography," ASTM Standard D 4059-86 in Vol. 10.03 Electrical Insulating Liquids and Gases (Philadelphia: American Society for Testing and Materials, 1987).

3. "Organochlorine Pesticides and PCB's," Test Methods for Evaluating Solid Waste, Physical/Chemical Methods, U.S. Environmental Protection Agency Publication No. SW-846 (3rd ed; Washington, DC: U.S. Government Printing Office, 1986), Method 8080.

4. R.G. Webb and A.C. MCCal1, "Quantitative PCB Standards for Electron Capture Gas Chromatography," J Chromatog Sci $11(7): 366$ (1973). 
Reviewed by:

Reviewed by:

Reviewed by:

Reviewed by:

Reviewed by:
Review date:

Review date:

Review date:

Review date:

Review date: 
THIS PAGE INTENTIONALLY LEFT BLANK

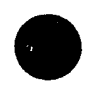

$\bullet$

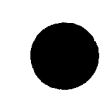

-

C. -38 


\section{ABSTRACT}

Certain chlorinated hydrocarbons, aiclehydes, and acids undergo the Fujiwara pyridine-alkali reactior, which produces a characteristic pink color. Estimatical of exposures to trichloroethylene by urine analysis is carried out by development of a pyridine-potassium hydroxide plus trichloroacetic acid (TCA) complex in an aliquot of raw urine. The complex concentration is measured at $530 \mathrm{~nm}$. The environmental health action level for trichloroacetic acid in urine is $15 \mathrm{mg} / \mathrm{liter}$.

\section{APPLICATIONS AND LIMITATIONS}

The absorbance produced by trichloroacetic acid following the Eujiwara reaction appears to be linear between 0 and 0.6 mmoles. However, the procedure is not specific for TCA. Chloroform, chloral hydrate, and unreacted trichloroethylene produce similar absorbances. Trichloroethanol does not interfere.

\section{APPARATUS}

Spectrophotometer, Hewlett-Packard Model $8450 \mathrm{~A}$

Assorted Izboratory glassware

\section{REAGENTS}

Toluene

Potassium hydroxide (3.3M) - Dissolve $185 \mathrm{~g}$ of $\mathrm{KOH}$ in 1 liter of distillad water.

Pyridine

Trichloroacetic acid stock solution (1000 $\mathrm{\mu g} \mathrm{TCA} / \mathrm{ml})$ Dissolve $1.0 \mathrm{~g}$ of TCA in 1 liter of distilled water. Standardize by titration with standard alkali.

Trichloroacetic acid standard $(50 \mu \mathrm{g} T \mathrm{TCA} / \mathrm{ml})$ - Dilute $5 \mathrm{ml}$ of TCA stock solution to $100 \mathrm{ml}$ with cistilled water. 


\section{ANALYTICAL PROCEDURE}

1. Mix $1 \mathrm{ml}$ of toluene, $5 \mathrm{ml}$ of $3.3 \mathrm{M} \mathrm{KOH}$, and $5 \mathrm{ml}$ of pyridine in a 40-ml centrifuge tube.

2. Add $1 \mathrm{ml}$ of urine, and place the tube in a boiling-water bath for 3 minutes.

3. Cool immediately in an ice-water bath.

4. Treat a blank and standards of 10,25 , and $50 \mu \mathrm{g}$ TCA in the same manner, i.e., add $1 \mathrm{ml}$ of standard $+5 \mathrm{ml}$ of $3.3 \mathrm{M} \mathrm{KOH}+$ $5 \mathrm{ml}$ of pyridine.

5. Remove the tubes from the ice bath when cool, and pipet $2 \mathrm{ml}$ of the organic phase into a 40-ml centrifuge tube containing $2 \mathrm{ml}$ of distilled water. Mix well.

6. Measure the absorbance of the blank, standards, and samples at $530 \mathrm{~nm}$ within 10 minutes of final mixing.

\section{CALCULATIONS}

Plot $\mu \mathrm{g}$ TCA versus absorbance of the standards. Read the sample concentration from this standard curve.

$\mathrm{mg} \mathrm{TCA} / \mathrm{liter}$ urine $=\mu \mathrm{g} \mathrm{TCA}$ in $1-\mathrm{ml}$ urine aliquot

\section{REEERENCES}

1. T.A. Seto and M.O. Schultze, "Determination of Trichloroethylene, Trichloroacetic Acid, and Trichloroethanol in Urine," Anal Chem 28:1625 (1956).

2. H.B. Elkins, The Chemistry of Industrial Toxicology (New York: J. Wiley \& Sons, Inc., 1.959), p. 405.

Reviewed by:

Reviewed by:

Reviewed by:

Reviewed by:

Reviewed by:
Review date:

Review date:

Review date:

Review date:

Review date: 


\title{
SECTION D
}

\section{GENERAL RADIOCHEMICAL PROCEDURES}

\begin{abstract}
A number of chemical procedures are used by the Sandia Laboratories Industrial Hygiene Chemistry Laboratory for the analysis of radioactive materials. Sandia Laboratories has maintained an environmental monitoring program (soil, water, and vegetation) since 1959. This program determines whether there is increased radiation exposure to the general public and to what magnitude. A number of routine measurements are made for gross alpha and beta activity in environmental samples.

Personnel working with radioactive materials, such as uranium and tritium, are occasionally sampled for the analysis of body fluids or wastes to detect possible exposure to radioactive materials. The information obtained is valuable when exposure has been due to radioisotopes that do not emit penetrating gamma radiation.

Other routine radiochemical survey programs consist of analyses of swipes for tritium and of gross alpha and beta counting of swipes and air filters for surface contamination.
\end{abstract}


THIS PAGE INTENTIONALLY LEFT BLANK

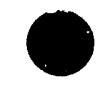

$\bullet$

$$
\text { D-2 }
$$


ENVIRONMENTAL SAMPLES

\section{VEGETATION SAMPLES}

A separate aliquot of the vegetation samples is taken for each radiochemical analysis. Air dry a $100-\mathrm{g}$ aliquot of vegetation (if available) to a constant dry mass. Finely grind the dry sample, and place it in a 500-ml Marinelli beaker for gamma spectrum analysis. Heat a second $100-\mathrm{g}$ aliquot with cyclohexane in a 1000-m1 distillation flask, and collect the water in a Barrett trap. Analyze a 1-ml sample of the collected water for tritium using a liquid scintillation counter (see "Tritium in Urine and Water and on Swipes," Section D of this Manual).

\section{SOIL SAMPLES}

To analyze soil samples for tritium, heat $100-\mathrm{g}$ aliquot with cyclohexane in a 1000-ml distillation flask, and collect the water in a Barrett trap. Analyze a 1-ml sample of the collected water for tritium using a liquid scintillation counter (see "Tritium in Urine and Water and on Swipes," Section D of this Manual). Uranium analysis of soils by laser phosphorimetry is described in "Total Uranium in Soil, Urine, and Water," Section D of this Manual.

\section{WATER SAMPLES}

To analyze water samples for gross alpha-beta activity, evaporate an aliquot of water (100 ml for alpha analysis; $400 \mathrm{ml}$ for beta analysis) on a $5-\mathrm{cm}$ diameter stainless steel planchet. Count the sample for 100 minutes using a low-background, gasproportional detector. Calibrate and check the detector routinely using NBS-traceable radionuclide standards (see "Gross Alpha and Beta Activity in Water," section D of this Manual).

\section{GAMMA RADIATION}

Analyze water, soil, and vegetation samples for gamma-emitting radionuclides using the American National standards Institute/ Institute of Electrical and Electronics Engineers (ANSI/IEEE) Standard 680-1978 (Standard Techniques for Determination of Germanium Semiconductor Detector Gamma Ray Efficiency Using a Standard Marinelli Beaker Geometry). Place approximately $450 \mathrm{~g}$ of water, $800 \mathrm{~g}$ of soil, or $100 \mathrm{~g}$ of vegetation in 500-m Marinelli beakers and count for 1000 minutes $(100$ minutes for soil) using high-efficiency, high-resolution intrinsic Ge or $\mathrm{Ge}(\mathrm{Li})$ detectors and multi-channel analyzers. Calibrate and check the detcctors routinely using either a mixed radionuclide 
standard obtained from the National Institute of Standards and Technology (NIST) or an NIST-traceable standard for specific radionuclides. The data are analyzed by computer software developed by Canberra Industries.

\section{REEERENCES}

1. S. Hwang et a1., 1989 Environmental Monitoring Report, Sandia National Laboratories, Albuquerque, New Mexico, SAND90-0301 (Albuquerque, NM: Sandia National Laboratories, 1990), Appendix C.

Reviewed by:

Reviewed by:

Reviewed by:

Reviewed by:

Reviewed by:
Review date:

Review date:

Review date:

Review date:

Review date: 


\section{ABSTRACT}

Gross quantities of alpha- and beta-emitting radionuclides (but not the identity of the nuclide) can be determined using a lowbackground internal proportional counter. A known volume of sample is concentrated and dried in a planchet before counting. Results are returned in disintigrations per minute (dpm). Tritium and other volatile radionuclides cannot be determined by this method.

\section{APPARATUS}

Planchets, stainless steel

Assorted laboratory glassware

\section{REAGENTS}

Indicator solution - Eriochrome Black $T$, commercially available through Van Waters and Rogers, Inc.

Buffer solution, pH 10 - Commercially available through Van Waters and Rogers, Inc.

Ethylenediaminetetraacetic acid (EDTA) disodium salt $(0.01 \mathrm{M}$ or $0.02 \mathrm{~N})$ - Dissolve $3.72 \mathrm{~g}$ of reagent-grade $\mathrm{Na}_{2}$ EDTA in 1 liter of distilled water, and dilute to volume $(1 \mathrm{ml}$ is equivalent to $1 \mathrm{mg}$ of $\mathrm{CaCO}_{3}$ ).

Nitric acid, conc. $\left(70 \% \mathrm{HNO}_{3}\right)$

Acetone

\section{ANALYTICAL PROCEDURE}

Dissolved Solids

1. Determine the hardness of the water sample by titrating a 50-ml aliquot with EDTA as follows:

a. To a 50-ml aliquot in a 250-ml beaker, add 4 drops of indicator and 10 drops of buffer; and swirl to mix. The solution should be wine-red. 
b. Titrate to a deep blue end-point, without the slightest trace of purple. In a 50-ml aliquot, $1 \mathrm{ml}$ of titrant = $20 \mathrm{mg} / \mathrm{liter}$ or $20 \mathrm{PPM}$ hardness as $\mathrm{CaCO}_{3}$.

2. Calculate the aliquot to be used in the gross alpha and beta determination. The final deposit on the planchet should be 4-7 $\mathrm{mg} / \mathrm{cm}^{2}$, or 80-140 $\mathrm{mg}$ for a 2-inch diameter planchet:

$\mathrm{ml}$ aliquot for 2 -inch planchet $=\frac{(110 \pm 30) \times 1000}{\mathrm{PPM} \times 2}$ *

3. Prepare all planchets beforehand.

a. Wipe the outer rim with a light film of silicone stopcock grease to prevent creep of the scale during evaporation.

b. Weigh to the nearest $0.1 \mathrm{mg}$.

4. Thoroughly shake all samples, filter through membrane hydrosol-type filters of 0.45-micron pore size, and save the filter papers for gross alpha and beta counting of total suspended solids.

5. Transfer the calculated, filtered aliquot to an appropriately sized beaker, add $2 \mathrm{ml}$ of conc. $\mathrm{HNO}_{3}$, and boil.

a. If the original aliquot is $200 \mathrm{ml}$ or less, boil it down to a few ml; transfer it quantitatively onto the planchet; and evaporate it to dryness.

b. If the original aliquot is greater than $200 \mathrm{ml}$, boil it down to one tenth of the original volume; and transfer it to a smaller beaker. When the volume is below $20 \mathrm{ml}$, transfer by portions to the prepared 2 -inch planchet. Evaporate the sample to complete dryness.

6. Reweigh the planchets and count for alpha and beta activity.

Suspended Solids

1. Transfer the membrane filter containing the suspended solids directly to a weighed planchet.

* Since the deposit is in nitrate form and all dissolved solids will appear on the planchet, the empirical factor 2 will convert conventional hardness figures to nitrate deposit. 
2. Lay the filter, solids-side down, onto the planchet, which has been wetted previously with a few drops of acetone. Fold the filter into quarters, if necessary, to make it fit. Add about $1 \mathrm{ml}$ of acetone to the planchet, thoroughly wetting the filter; and let it stand until the filter is substantially dissolved.

3. Burn off the acetone, and flame the residue briefly.

4. Let cool, weigh, and count for alpha and beta activity.

\section{REEERENCES}

1. Radiochemical Analytical Procedures for Analysis of Environmental Samples, Publication No. EMSL-LV-0539-17 (Las Vegas, NV: U.S. Environmental Protection Agency, 1979).

Reviewed by:

Reviewed by:

Reviewed by:

Reviewed by:

Reviewed by:
Review date:

Review date:

Review date:

Review date:

Review date: 


\section{THIS PAGE INTENTIONALLY LEFT BLANK}

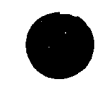




\title{
TRITIUM IN URINE AND WATER AND ON SWIPES
}

\begin{abstract}
Liquid scintillation counting is a method of detecting radioactivity by means of a solution of fluors and a photomultiplier tube. The scintillation solution converts the radioactivity to light, and the phototube responds by producing a charged pulse which can be counted.
\end{abstract}

\section{APPLICATIONS AND LIMITATIONS}

The widest application of liquid scintillation counting in the Industrial Hygiene Chemistry Laboratory is the determination of tritium in biological fluids, swipes, and water. Untreated urine and water are added directly to a scintillation cocktail and counted with a scintillation spectrometer. Swipes are placed directly in counting vials and wetted with water before the scintillator fluid is added.

The lower limits of detection for liquid scintillation counting are 1 disintigration per minute $(\mathrm{dpm})$ for swipes, $0.45 \mathrm{pCi} / \mathrm{ml}$ for water or urine.

\section{ES\&H NOTES}

Samples with potentially-high tritium levels should be handled in such a way to avoid spreading contamination, either to the laboratory staff or on laboratory or instrument surfaces.

\section{APPARATUS}

Liquid scintillation counter, TM Analytic Mark V Model 5303 Counting vials, 7 and $20 \mathrm{ml}$, glass and polyethylene with plastic screw caps

Assorted laboratory glassware

Pipet, $1 \mathrm{ml}$ liquid

\section{REAGENTS}

Opti-Eluor, commercially available from Packard Instrument Co.

Tritium standard, commercially available from Amersham (Arlington, IL), $<0.07 \mathrm{pCi}$ 
Reference background water, commercially available from Amersham (Arlington, IL)

Quenched tritium standards, commercially available from Amersham (Arlington, IL), 7 concentrations

\section{SAMPLE PREPARATION}

Wash hands before beginning sample preparation to limit chemiluminescence from creams and oils sometimes present on hands.

\section{Urine}

1. Pipet $1 \mathrm{ml}$ of urine into a polyethylene counting vial. Add $15 \mathrm{ml}$ of scintillator fluid, cap, and $\mathrm{mix}$ thoroughly.

2. Wipe the outside of the vial to remove fingerprints.

3. Dark adapt the sample for 30 minutes before counting to eliminate interference from chemiluminescence.

Alternatively, rerun the sample 3-4 times until a steady value is obtained.

Water and Other Fluids

1. Pipet $1 \mathrm{ml}$ of water into a scintillation vial.

2. Add $15 \mathrm{ml}$ of scintil. ator fluid, and mix thoroughly. Wipe the outside of the vial to remove fingerprints.

Swipes and Swabs

1. Place the swipe or swab into a glass scintillation vial.

2. Wet the swipe with $1 \mathrm{ml}$ of distilled water.

3. Add $15 \mathrm{ml}$ of scintillator fluid, and mix thoroughly. Wipe the outside of the vial to remove fingerprints.

Cotton Balls

1. Place the cotton ball into a glass scintillation vial.

2. Add $5 \mathrm{ml}$ of distilled water, and soak for at least 1 hour, agitating occasionally.

3. Pipet $1 \mathrm{ml}$ of the liquid into another vial, add $15 \mathrm{ml}$ of scintillator fluid, and mix thoroughly. Wipe the outside of the vial to remove fingerprints. 


\section{ANALYTICAL PROCEDURE}

1. Place the sample vials in numbered trays, starting at the end away from the number. The first 2 samples should be the standard and the sample blank. If desired, end with a Reference water blank. Place the trays in the counter.

2. Start the computer, and select the COUNTER program (\#1).

3. To set up the program, select BATCHES (\#1). Edit program Tritium 1: NUMBER OF RUNS is generally 1 or Continuous (C), if you wish to repeat the analyses until the values stabilize. START TRAY NO. must be the first tray in the sequence.

NOTE: The usual values for the program are as follows: ID Tritium 1

Mode DPM CQ SNGL

Low energy std Current Curve number

High energy std Unassigned

$\mathrm{K}$ factor 1

Time terminator 5.00

(You may change the time after the program starts. Urines are usually run for 30 minutes.)

Photon monitor ON

$\mathrm{H} 3$ range $1-16 \mathrm{KEV}$

4. Select START COUNTER (\#4), and START when ready.

\section{CALCULATIONS}

The instrumental printout includes values for counts per minute $(\mathrm{cpm})$, disintigrations per minute (dpm), and efficiency (eff). Concentration is usually determined in $\mathrm{dpm}$, the blank value being subtracted before reporting.

If the value is high enough that dpm isn't calculated by the instrument, manually calculate it as follows:

$$
\text { Dpm }=\frac{(\text { Sample } \mathrm{cpm})-(\mathrm{Blank} \mathrm{cpm})}{\mathrm{eff}}
$$

For liquid samples, convert disintigrations per minute to $\mathrm{pCi} / \mathrm{ml}$ by multiplying the dpm value by 0.45 .

\section{CALIBRATION AND QUALITY CONTROL}

1. Approximately every 6 months, analyze 7 working standards in the liquid scintillation spectrometer (Amersham Quenched Tritium Standards, Cat. No. 180070). Correct the tritium 
values for decay, using the Universal Decay Table (Table D-1). Store the values as a new calibration curve in the instrument.

2. Maintain the standardization by analyzing a blank and a tritium standard with each set of urine samples.

3. The value of the tritium blank and the efficiency of the tritium standard are tracked on control charts.

\section{REEERENCES}

1. F.E. Butler, "Determination of Tritilum in Water and Irine," Anal Chem 33:409 (1961).

2. W.H. Langham et al., "Assay of Tritium Activity in Body Fluids with Use of a Liquid Scintillation System," J Lab and Clin Med 47:819 (1956).

3. Mark V Model 5303 Liquid Scintillation Counting system User's Manual, Documerit No. 710-A50200, Issue B (TM Analytic, $8 / 1 / 90)$.

Reviewed by:

Review date:

Reviewed by:

Review date:

Reviewed by:

Review date:

Reviewed by:

Review date:

Reviewed by:

Review date: 


\section{UNIVERSAL DECAY TABLE ACCESSOFIES STATISTICS}

\section{A.1 ISOTOPE DECAY TABLES}

The Universal Decay Table provides the fraction of activity of a radioisotope remaining, from 0.901 half-life to 1.000 half-life, as calculated fror the equation $A / A O=e-\lambda t=e-0693 t / T^{2}$ where Ao is the known activity in dpm at a known past date, and $A$ is the unknown present activity. To use this table:

(1) Determine the half-life of the isotope of interest.

For commonly used isotopes:

ISOTOPE

${ }^{3} \mathrm{H}$
$1{ }^{4} \mathrm{C}$
$2{ }^{2} \mathrm{Na}$
$2{ }^{4} \mathrm{Na}$
$32 \mathrm{P}$
$35 \mathrm{~S}$
${ }^{36} \mathrm{Cl}$
${ }^{45} \mathrm{Ca}$
${ }^{60} \mathrm{Co}$

HALF-LIFE

12.3 years
5730 years
2.60 years
15.0 hours
14.3 days
88 days
3.1 y $10^{5}$ years
165 day's
5.26 years

(2) Divide the elapsed time (t) by half-life ( $\left.T_{1}, 2\right)$. Time must be in the same units. Enter the table at this ratio to observe the Eraction of remaining activity.

(3) Multiply the original activity by this figure to obtain the present cotivity.

Exampla:

Determine the present activity of a 3 Hi standard that hac $250,000+3 z$ dym exactly 1 year ago.

(1) $t=1$ year and T/ $=12.3$ years, thus $t / \% 1 / 2=0.0313$.

(2) Entering the table at the 0.080 row ared extrapolating between the oul ard .092 columns for the 0.0313 value qives 0.94502 at the fraction remaining.

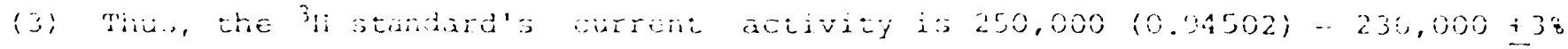
(i) in. 
UNIVERSAL DECAY TABLE

ACTIVITY REMAINING FOR $t / T_{\frac{1}{}}$ FROM .001 TO 1.00

\begin{tabular}{|c|c|c|c|c|c|c|c|c|c|c|}
\hline & .000 & 001 & 002 & .003 & .004 & .005 & .006 & .007 & .008 & .009 \\
\hline .000 & 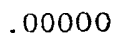 & 969 & 9002 & 793 & 99723 & 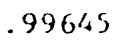 & 100 & .99516 & .99446 & 79 \\
\hline .010 & & & 99172 & & & 98966 & & & .98759 & .98693 \\
\hline .020 & & 8554 & .98487 & .98419 & .98350 & .98243 & .98214 & .98146 & .98076 & \\
\hline .030 & .97942 & .97874 & .97807 & .97740 & .97671 & .97603 & .97517 & .97446 & .97 & \\
\hline .040 & .97262 & .97299 & .97132 & .97065 & .96997 & .96930 & & .96795 & & \\
\hline .050 & .96594 & .96527 & .96461 & .96393 & .96 & .96260 & 90 & .96125 & & \\
\hline .060 & .95928 & .95862 & .95795 & .95728 & .95661 & .95596 & 29 & .95 & & \\
\hline .070 & .95264 & .95199 & .95133 & & .95 & .94936 & 70 & .94 & & \\
\hline .080 & .94587 & .94522 & .94457 & .94 & .94 & .94261 & 96 & .91 & & \\
\hline .090 & .93926 & .93888 & .93 & .9 & .9 & .93 & & .93 & & \\
\hline .100 & .93 & .93240 & .93 & .9 & .93 & .92982 & .92 & .92 & & \\
\hline .110 & .92 & .92 & .92 & & & .92 & & & & \\
\hline .120 & .92 & .9 & .91 & .9 & & .91 & & & & .91 .40 \\
\hline .130 & & .9 & .9 & & & & & & & \\
\hline .140 & & .9 & .9 & & & & & & & \\
\hline .150 & .9 & .90 & .9 & & & .8 & & & & .89566 \\
\hline .160 & .8 & .89 & .8 & & & .8 & & & & .88949 \\
\hline .170 & .8 & .88 & $.8 \varepsilon$ & & & & & & & .88 \\
\hline .180 & .88 & .8 & .8 & & & .8 & .8 & & & .87 \\
\hline .190 & .8 & .8 & .8 & & & & & & & \\
\hline .200 & .8 & & .86 & & & & & & & .86 \\
\hline .210 & .8 & & & & & & .8 & & .85 & .85 \\
\hline .220 & 59 & & & & & & & & .85 & .85326 \\
\hline .230 & 66 & & .8 & & & & .84 & & .84 & .84736 \\
\hline .24 & .84 & & & & & .84 & .84 & .8 & .84 & .84 \\
\hline .250 & .84 & & & .8 & & .87 & .83 & .8 & .83 & .83 \\
\hline .260 & & & & & & & & & .83 & \\
\hline .220 & .82 & & & & & .82 & & .82 & .82 & .82 \\
\hline .280 & .82 & & & & .82 & .82 & .8 .2 & .81 & .8 & .81 \\
\hline .290 & .81 & & & & & .81 & 54 & .81 & .81341 & \\
\hline .3190 & & & & & & .80 & 392 & .80 & .80779 & \\
\hline .310 & & & & & & .80 & .80333 & .80 & .80222 & .80 \\
\hline .320 & & & & & & .238 & .79779 & .79731 & .79668 & \\
\hline .330 & & & & & & .79282 & .73227 & .79172 & .79118 & \\
\hline .360 & & & & & & .78735 & .78681 & .78625 & .78571 & .78 \\
\hline .350 & .79 & & & .78 & .78 & .78191 & .78137 & $.70 \cup 82$ & .78028 & .77974 \\
\hline .560 & & & & .777 & .77704 & $.776,48$ & .71597 & .77543 & .77489 & .77436 \\
\hline .310 & & & .77275 & .77222 & .77163 & .77115 & .73062 & .77007 & & $.7690,1$ \\
\hline set: & $.76,5 \% 4$ & $.76,795$ & & & & .76582 & .76599 & .764 .76 & & 30 \\
\hline .4 & $.75: 17$ & $.76,272$ & $.76,212$ & $.7615 \%$ & & $.760,53$ &.$i 60001$ & .7 & .75 & 75863 \\
\hline$\therefore \%$, & . & .75737 & .75585 & .75633 & .75580 & .15528 & .75030 & $.75 \div 4: 3$ & 71 & 79319 \\
\hline$\therefore 1 !$ & $\because ? f_{1} f_{3}$ & .75215 & .75163 & .75111 & .75 & .11 & & .74902 & .74 .856 & .14799 \\
\hline$(\cdots 2)$ & $\therefore a$ & .740515 & $.76 .5 \% 4$ & $.1454 ?$ & .11 & $.1 \%$ & .16 .637 & $.7 x$ & .74334 & .34282 \\
\hline$\therefore 3 i$ & $.7+231$ & $.7 \div 173$ & .74128 & .74077 & .14 & .79976 & .13923 & .73871 & .73820 & .73762 \\
\hline$\therefore \ldots i j$ & .11118 & $.736,632$ & .73616 & .73568 & .7 & .231463 & .73413 & .73361 & .73311 & .73260 \\
\hline $.0 \% 9$ & .93004 & .73258 & .73108 & .73057 & .130006 & .72356 & .72458 & .72854 & $.7280 \%$ & .72754 \\
\hline.$t \cdot f(j)$ & .72708 & $.726,53$ & .72603 & .72545 & .72527 & .72452 & .72407 & .72351 & .72302 & .72252 \\
\hline$\therefore 74$ & .72201 & .72151 & .12107 & .72052 & .72001 & .11352 & .71307 & .71857 & $.7180 ?$ & .71753 \\
\hline .480 & .11702 & $.74,3$ & .716 & .11534 & .71504 & .11455 & .111 .05 & .71355 & .71306 & .71257 \\
\hline$\therefore 90$ & .71207 & $.71: 08$ & .711 & $.7106,0$ & .81010 & 70361 & ? & .70863 & .70814 & .70765 \\
\hline$\therefore 00$ & 30715 & $.706,6,6$ & 20618 & $.7056,3$ & .70520 & $10)+11$ & .10423 & .70373 & 70325 & 70276 \\
\hline
\end{tabular}


UNIVERSAL DECAY TABLE--Cont Inued

ACTIVITY REMAINLNG FOR $t / T_{t}$ FROM .001 TO 1.00

\begin{tabular}{|c|c|c|c|c|c|c|c|c|c|c|}
\hline & .000 & .001 & .002 & .003 & .004 & .005 & .006 & .007 & .008 & .009 \\
\hline .510 & .70227 & .70179 & .70130 & .70082 & .70033 & .69984 & .69936 & .69887 & .69639 & .69791 \\
\hline .520 & .69742 & .69694 & .69646 & .69598 & .69549 & .69501 & .69453 & .69404 & .69356 & .69309 \\
\hline .530 & .69261 & .69213 & .69165 & .69117 & .69069 & .69021 & .68973 & .68925 & .68871 & .68830 \\
\hline .540 & .68796 & .68735 & .68687 & .68640 & .68593 & .68545 & .68497 & .68450 & .68395 & .68348 \\
\hline .550 & .68 .307 & .68260 & .68213 & .68166 & .68118 & .68071 & .68024 & .67976 & .67913 & .67882 \\
\hline .560 & .66835 & .67782 & .67742 & .67695 & .67646 & .67601 & .67554 & .67507 & .67461 & .67414 \\
\hline .570 & .67367 & .67320 & .67274 & .67227 & .67181 & .67134 & .67088 & .67041 & .66995 & .66948 \\
\hline .580 & .66902 & .66856 & .66810 & .66764 & .66718 & .66671 & .06624 & .66578 & .66532 & .66486 \\
\hline .590 & .66440 & .66394 & .66348 & .66302 & .66256 & .66210 & .66164 & .66118 & .66053 & .66027 \\
\hline .600 & .65981 & .65935 & .65890 & .65846 & .65798 & .65753 & .65707 & .65661 & 516 & 571 \\
\hline .610 & .65525 & .65480 & .65435 & .65390 & .65344 & .65299 & .65244 & .65208 & .65163 & .65118 \\
\hline .620 & .65073 & .65028 & .64983 & .64938 & .64892 & .64848 & .64803 & .64758 & .64713 & .64669 \\
\hline .630 & .64623 & .64598 & .64534 & .54489 & .64448 & .64400 & .64356 & .64310 & .64273 & .64222 \\
\hline .640 & .64178 & .64133 & .64089 & .64044 & .64000 & .63955 & .63911 & .63886 & 22 & .63778 \\
\hline .650 & .63764 & .63690 & .63646 & .63602 & .63558 & .63514 & .63470 & +25 & .6 & .6 \\
\hline .660 & .63293 & .63250 & .63206 & .63163 & .63118 & .63075 & .63032 & .62987 & .62944 & .62900 \\
\hline .670 & .62856 & .62813 & .62770 & .62727 & .62683 & .02639 & .62588 & .62552 & 509 & .62466 \\
\hline .680 & .62422 & .62379 & .62336 & .62293 & .62250 & .62207 & .62164 & .62120 & .6 & .6 \\
\hline .690 & .61991 & .61936 & .61906 & .61863 & .51820 & .61777 & .61736 & .61691 & 49 & .61606 \\
\hline .700 & .61563 & .61520 & .61478 & .61436 & .61393 & .61350 & .61308 & .61265 & 23 & .6 \\
\hline .710 & .61138 & .61096 & .61054 & .61012 & 369 & .60927 & .60885 & .60842 & 00 & .6 \\
\hline .720 & .60716 & .60674 & .60632 & .60572 & .60548 & .60506 & .60464 & +22 & 380 & .60339 \\
\hline .730 & .60296 & .60255 & .60213 & .60172 & .60130 & . fnOn88 & .60 & .6 & 63 & .5 \\
\hline .740 & .59880 & .59838 & .59797 & .53756 & .59717 & .59613 & .59632 & .59590 & .59549 & .59508 \\
\hline .750 & .59456 & .59426 & .59385 & $.5934 \therefore$ & .59302 & .59201 & .59220 & .59179 & .59144 & .59097 \\
\hline .760 & .59053 & & .58974 & .58934 & & & & & & \\
\hline .770 & .58648 & .58608 & .58567 & .58527 & .58485 & .58477 & .58405 & .58364 & .58324 & .58271 \\
\hline .780 & .58243 & .58202 & .58163 & .58122 & .58032 & .58042 & .58002 & .57961 & .57921 & .57910 \\
\hline .730 & $.578 t$ & & .57761 & .57721 & .57681 & .57641 & 001 & .57561 & & \\
\hline .800 & $.574 \div 1$ & .57402 & .59362 & .57317 & .57282 & .57243 & .57204 & .57163 & .57124 & .57085 \\
\hline .810 & .57045 & .57005 & .56366 & $.5690 \%$ & .55850 & $.5084 i$ & .56808 & .56768 & .56729 & .56690 \\
\hline .520 & .56645 & $.566: 1$ & .56572 & .56533 & $.3044 !$ & .56455 & 56426 & & & .5 \\
\hline .830 & .56359 & .56320 & .56282 & .56243 & .50203 & .56165 & $.56: 26$ & .56087 & .56049 & .56010 \\
\hline .840 & .55839 & $.5583 ?$ & .55794 & .55735 & $.55: 16$ & $.556,78$ & .55640 & .55601 & .55562 & .55524 \\
\hline .850 & .55485 & .55447 & $.55 \div 08$ &. $.553 \%$ & .55923 & .53243 & 55255 & .5 & & .5 \\
\hline .860 & $.5510 ?$ & .55064 & .55026 & .54303 & .524 .0 & .51 .312 & $.34,4,74$ & $.5 i .8141$ & .54797 & .54760 \\
\hline .870 & .54721 & .54683 & .54646 & .54605 & $.545,5$ & 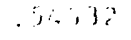 & .34495 & $.54 \div 57$ & .54419 & .54382 \\
\hline .880 & .5431 .4 & .54506 & .54269 & $.5 \div 23 i$ & $.34: 13$ & $.31,6$ & $-5 a+1 ! 8$ & .51 .081 & .54043 & .52 \\
\hline .890 & $.5396,5$ & $.5343 i$ & .33894 & .53854 & $\therefore 34 \mathrm{i}$ & $.5: 132$ &.$\quad 33 \therefore 3$ & .53702 & .53670 & .53533 \\
\hline $.7(1 i)$ & .53595 & .53538 & .53538 & .3348 &.$\because 3 \therefore \therefore 1$ & $\therefore 3 \therefore 11$ & .03373 & .53336 & .53299 & .53262 \\
\hline $.3 ! 0$ & .33205 & .53188 & .53152 & .53115 & $\therefore 3078$ & $\therefore 30 \div 3$ & $3: 3005$ & .52968 & .52931 & .52895 \\
\hline .920 & .52858 & .52821 & .2785 & $.527 i n$ & $\therefore ? 11$ & $\therefore 1: 7$ & .92636 & $.326,00$ & .52566 & .52529 \\
\hline .430 & .52493 & .52456 & .32420 & $.5234:$ & $\because 3 \therefore$ & : : : 1: ! ! & .3275 & .52234 & .52203 & .52168 \\
\hline . sit? & .52130 & .520134 & $.320>8$ & $.221 \%$ & $.3: ; . ; 3$ & . $, 1: \cdots$ & $\Rightarrow 1316$ & $\therefore 1348$ & .51842 & $.5 ! 806$ \\
\hline .450 & .51770 & .5173 & .51698 & $.5 ! 64 !$ & $.311,1 i$ & $\therefore 1,1$ & $: 1: 5$ & .3520 & .514 .84 & .51448 \\
\hline .340 & $.5160 ?$ & .51377 & $.313 \div 2$ & $.5 ! 300$ & $512 ? 0$ & .1123 & $.3(60$ & 5116 & .51129 & .51093 \\
\hline .970 & .51057 & .51027 & $.50 \div 87$ & $.509 ; 2$ & .30318 & 1.50841 & . $10,8+6$ & .50810 & .50775 & .30740 \\
\hline .980 & .50715 & $.506,70$ & .50635 & $.5(06,0) i$ & $.11,10$ & . Bis , is & 30145 & $.50 / 000$ & .50426 & .50390 \\
\hline .990 & .50355 & .50320 & .50285 & .50236 & $.50 \div 16$ & $.5118 !$ & $\because 6,1: 1$ & .0111 & .50077 & .50042 \\
\hline 1. .900 & $.5(3006)$ & 49973 & .49938 & $.4530 \%$ & $(0.48,9$ & .4438 & . .4xin & .49765 & .49731 & .1 .9097 \\
\hline
\end{tabular}


THIS PAGE INTENTIONALLY LEFT BLANK

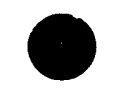

D- 16 
TOTAL URANIUM IN SOIL, URINE, AND WATER

\begin{abstract}
A pulsed laser is used to induce phosphorescence from uranium ions, which are complexed with a proprietary complexing agent to produce reasonable decay lifetimes at room temperature. The number of photons detected is proportional to the number of excited ions. Intensity values, taken at fixed intervals, are summed to give good statistics and repeatability.
\end{abstract}

\title{
APPLICATIONS AND LIMITATIONS
}

The detection limit for the technique is approximately $0.03 \mathrm{ng}$ of uranium. The low range covers the detection limit to $>10 \mathrm{ng}$; high range, $10 \mathrm{ng}$ to $10 \mu \mathrm{g}$. Relative standard deviations of $1-2 \%$ are common.

\section{ES\&H NOTES}

The KPA-10 is classified as a Class Ib laser system. The laser is interlocked to turn off when the sample chamber door is opened. Nevertheless, do not open the door while the laser indicator is on to avoid exposing the photomultiplier tubes to excess light.

\section{APPARATUS}

Laser phosphorimeter, Chemchek Instruments Model KPA-10

Quartz cells, with Teflon stoppers

Pipets, liquid

Erlenmeyer flasks

Graduated cylinders, 5 or $10 \mathrm{ml}$

\section{REAGENTS}

Laser dye mix - Dissolve $23.9 \mathrm{mg}$ of stilbene-420 in $25 \mathrm{ml}$ of methanol.

Nitric acid, conc. $\left(70 \% \mathrm{HNO}_{3}\right)$

Hydrogen peroxide $(30 \%)$

Uranium stock standard (1000 $\mu \mathrm{g} \mathrm{U} / \mathrm{ml})$ - A commercialiyprepared stock standard in nitric acid is used. 
Uranium working standards - Prepare working standards of $0.1,1$, and $10 \mu \mathrm{g} / \mathrm{ml}$, acidified to the same strength as the stock standard.

Uraplex complexing agent, available from ChemChek Incorporated

\section{SAMPLE PREPARATION}

\section{Water Samples}

1. Water samples can be analyzed directly or concentrated by evaporation with $2 \mathrm{~N} \mathrm{HNO}_{3}$ to a smaller volume.

2. Pipet $1 \mathrm{ml}$ of water $+1.5 \mathrm{ml}$ of complexing agent into the cell. Insert a clean Teflon stopper into the cell and invert several times to $\mathrm{mix}$, touching only the top and bottom of the cell.

Urine Samples

1. Vigorously shake the urine sample to homogenize, since uranium tends to concentrate in the solids.

2. Digest $5 \mathrm{ml}$ of the homogenized urine in an Erlenmeyer flask with $2 \mathrm{ml}$ of conc. $\mathrm{HNO}_{3}$ and $0.5 \mathrm{ml}$ of $\mathrm{H}_{2} \mathrm{O}_{2}$. Heat, repeating the addition of oxidents 1-2 times as needed, until a pale yellow or white salt forms.

3. Redissolve the salts in a little conc. $\mathrm{HNO}_{3}$ and deionized water, and dilute to 5 or $10 \mathrm{ml}$, as desired.

4. Combine $1 \mathrm{ml}$ of the digested sample (NOTE: Avoid pipetting any solids.) with $1.5 \mathrm{ml}$ of complexing agent.

\section{Soil Samples}

1. Add a known weight, 5-10 g, of soil to an Erlenmeyer flask.

2. Cover with conc. $\mathrm{HNO}_{3}$ and $\mathrm{H}_{2} \mathrm{O}_{2}$ in the ratio $4: 1$. Digest as in Step 2 under Urine Samples.

3. Add a little conc. $\mathrm{HNO}_{3}$ and deionized water, filter, and dilute to 5 or $10 \mathrm{ml}$, as desired.

4. Combine $1 \mathrm{ml}$ of sample with $1.5 \mathrm{ml}$ of complexing agent.

\section{ANALYTICAL PROCEDURE}

1. Turn on the KPA and the computer.

2. Prepare the Uraplex complexing agent. 
3. Eill the reference cell with a solution of 100-400 ng of uranium in Uraplex to give 20-70 counts/pulse. Place the cell in the right-hand cell holder in the door of the KPA. The reference solution should be replaced approximately monthly (or when the coefficient of linearity value, $R^{2}$, drops below 0.99).

4. Before using any cell, test the background level by running with $1 \mathrm{ml}$ of distilled water $+1.5 \mathrm{ml}$ of complexing agent. The background should be 300 counts or less in the low range and 20 or less in the high range. If it is higher, rinse the cell repeatedly with distilled water and complexing agent until the level is acceptable.

5. When ready to run, insert the cell into the left-hand cell holder in the door of the KPA-10, being careful to avoid breakage or getting fingerprints on it. If you do touch the cell, clean it with methanol; and rinse with distilled water.

6. From the Main Menu, select F5 REFERENCE SOLUTION DATA. Enter the date the reference solution was prepared. The reference solution should be replace when the lifetime falls below $200 \mu \mathrm{s}$ or the $\mathrm{R}^{2}$, below 0.99 .

7. Select F2 CALIBRATE to access the Calibration Menu, then F1 CALIBRATION. Calibration consists of a background measurement (which is subsequently subtracted from all other measurements) and from 1 to 7 standards per range. Most of our samples are run in the High range, using 3 standards.

a. Select the appropriate range using PgUp or PgDn.

b. Select F2 EDIT CALIBRATION INFO to enter the standard concentrations and units.

c. Eill a rinsed cell with $1 \mathrm{ml}$ of deionized water $+1.5 \mathrm{ml}$ of complexing agent, and insert it into the left-hand cell holder. Select F3 BACKGROUND to run the background measurerient.

d. Fill a rinsed cell with $1 \mathrm{ml}$ of the first standard +1.5 $\mathrm{ml}$ of complexing agent. Select F1 STANDARD to measure the first standard. Repeat for all standards.

8. Fill a rinsed cell with $1 \mathrm{ml}$ of sample $+1.5 \mathrm{ml}$ of coinplexing agent.

a. Select El ANALYZE from the Main Menu to access the Sample Analysis Menu.

b. Select F1 ANALYSIS OF SAMPLE, and enter the requested information. Press $\mathrm{F} 1$ again when ready to begin the analysis. 
c. The analytical report, displayed after each analysis, may be printed by pressing F2 PRINT REPORT.

d. Repeat for all samples using F1 ANALYZE NEXT SAMPLE.

\section{REEERENCES}

1. Operation and Service Manual for Kinetic Phosphorescence analyzer KPA-10 (Richland, WA: ChemCheck Instruments).

Reviewed by:

Reviewed by:

Reviewed by:

Reviewed by:

Reviewed by:
Review date:

Review date:

Review date:

Review date:

Review date: 


\section{DISTRI BUT ION :}

$\begin{array}{rll}1 & 2131-1 & \text { J.S. Downs } \\ 1 & 7710 & \text { W.D. Burnett } \\ 1 & 7711 & \text { C.J. Pigg } \\ 1 & 7711 & \text { J. Anglen } \\ 1 & 7711 & \text { D.H. Bridgers } \\ 1 & 7711 & \text { V.R. Cibicki } \\ 1 & 7711 & \text { D. L. Goodwin } \\ 1 & 7711 & \text { P.S. Herring } \\ 1 & 7711 & \text { A. Jimenez } \\ 1 & 7711 & \text { B.M. Kelly } \\ 1 & 7711 & \text { C.L. Lucas } \\ 1 & 7711 & \text { B.A. Philipbar } \\ 1 & 7711 & \text { G.J. Pirtle } \\ 1 & 7711 & \text { A.L. Rader } \\ 1 & 7711 & \text { C.M. Schaub } \\ 1 & 7711 & \text { D.G. Sepulveda } \\ 1 & 7711 & \text { W.E. Stocum } \\ 1 & 7711 & \text { L.B. Taylor } \\ 1 & 7711 & \text { J. Zamora } \\ 11 & 7711 & \text { C.E. Gray } \\ 11 & 7711 & \text { K.A. Greulich } \\ 1 & 7712 & \text { J.R. Guth } \\ 1 & 8541 & \text { V.A. Levin } \\ 1 & 8541 & \text { D.E. Patrician } \\ 5 & 3141 & \text { S.A. Landenberger (Technical Library) } \\ 8 & 3141-1 & \text { Document Processing DOE/OSTI } \\ 3 & 3151 & \text { G.C. Claycomb } \\ 1 & 8524 & \text { R.C. Christman }\end{array}$

Margret Gautier

Los Alamos National Laboratory

Mail Stop K484

Los Alamos, NM 87545 

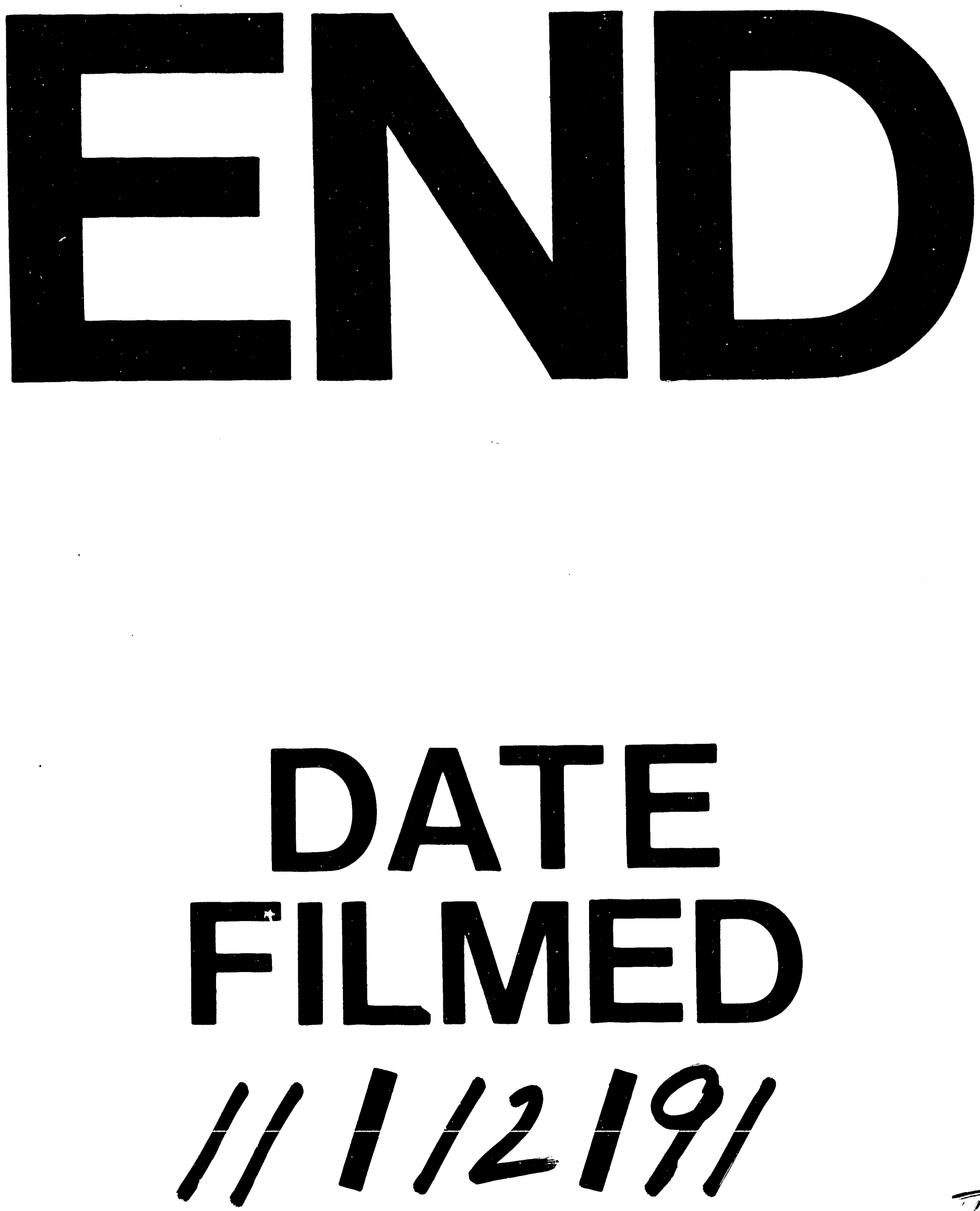
